\title{
Archeological Survey of a Portion of Old Velasco (41B0125) for the Village of Surfside Beach Proposed Boat Ramp Facility, Brazoria County, Texas
}

Jennifer K. McWilliams

Texas Historical Commission

Douglas K. Boyd

Prewitt and Associates, Inc.

Follow this and additional works at: https://scholarworks.sfasu.edu/ita

Part of the American Material Culture Commons, Archaeological Anthropology Commons, Environmental Studies Commons, Other American Studies Commons, Other Arts and Humanities Commons, Other History of Art, Architecture, and Archaeology Commons, and the United States History Commons

Tell us how this article helped you.

This Article is brought to you for free and open access by the Center for Regional Heritage Research at SFA ScholarWorks. It has been accepted for inclusion in Index of Texas Archaeology: Open Access Gray Literature from the Lone Star State by an authorized editor of SFA ScholarWorks. For more information, please contact cdsscholarworks@sfasu.edu. 


\section{Archeological Survey of a Portion of Old Velasco (41B0125) for the Village of Surfside Beach Proposed Boat Ramp Facility, Brazoria County, Texas}

\section{Creative Commons License}

\section{(c) (i) $\Theta($}

This work is licensed under a Creative Commons Attribution-NonCommercial-No Derivative Works 4.0 International License. 


\title{
ARCHEOLOGICAL SURVEY OF A PORTION OF OLD VELASCO (41BO125) FOR THE VILLAGE OF SURFSIDE BEACH PROPOSED BOAT RAMP FACILITY, BRAZORIA COUNTY, TEXAS
}

\author{
by \\ Jennifer K. McWilliams and Douglas K. Boyd \\ with contributions by \\ Johnney T. Pollan, Jr., Sandra D. Pollan, James L. Smith, and Brian S. Shaffer
}

Principal Investigator: Douglas K. Boyd

REPORTS OF INVESTIGATIONS, NUMBER 150

Prewitt and Associates, Inc.

Cultural Resources Services

Austin, Texas

PAI No. 206005

January 2007

TEXAS ANTIQUITIES PERMIT NO. 4027 



\section{TABLE OF CONTENTS}

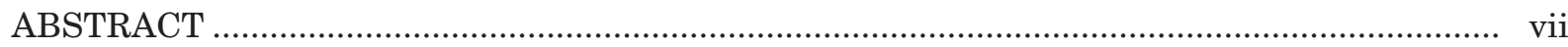

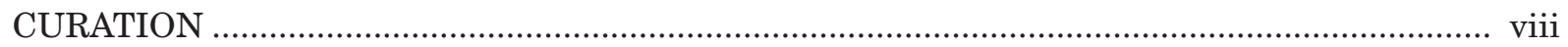

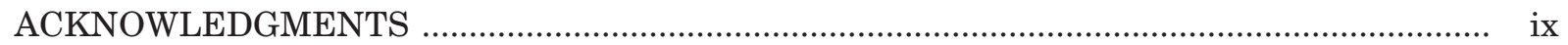

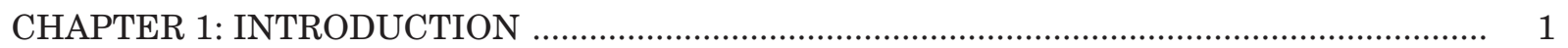

CHAPTER 2: HISTORICAL AND ARCHEOLOGICAL OVERVIEW OF OLD VELASCO

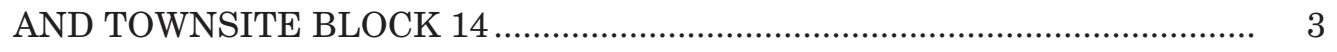

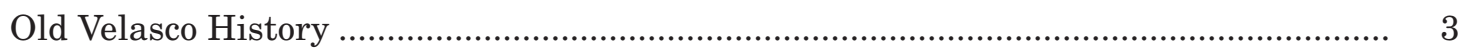

Previous Archeological Investigations at Old Velasco .............................................. 7

Block 14 Building History ............................................................................................. 8

CHAPTER 3: METHODS OF INVESTIGATION AND WORK ACCOMPLISHED ................... 13

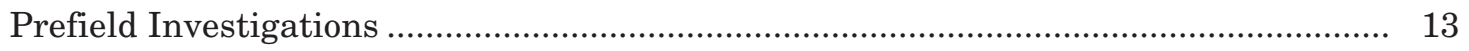

Methods of Archeological Investigation ........................................................................ 14

Work Accomplished and Results of Investigations ...................................................... 14

Northern Portion of the Project Area ............................................................. 16

Southern Portion of the Project Area .................................................................. 18

CHAPTER 4: DESCRIPTION AND INTERPRETATION OF NINETEENTH-CENTURY FEATURES AND ARTIFACTS ................................................................... 23

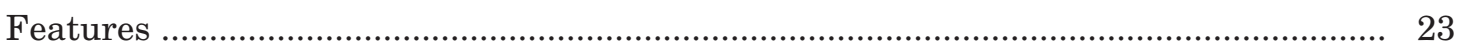

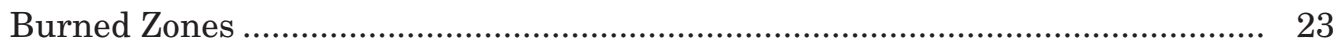

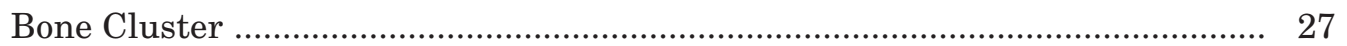

Bone Pit Features ......................................................................................... 27

Wooden Posts ............................................................................................. 28

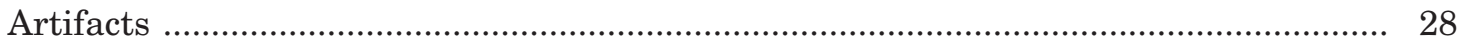

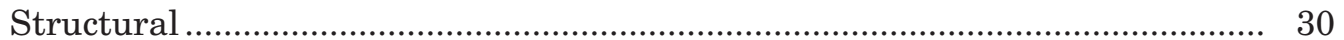

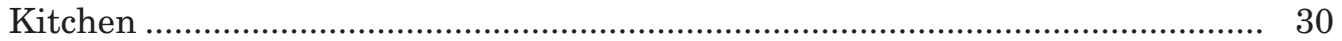

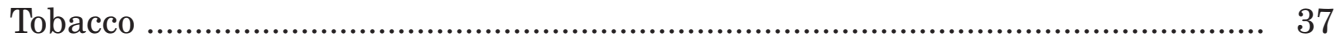

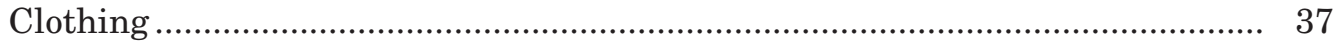

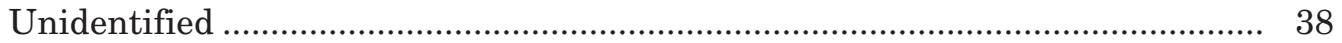

CHAPTER 5: INTERPRETATIONS, SUMMARY, AND AND RECOMMENDATIONS ............ 41

Interpretations of Artifacts and Features from Old Velasco ......................................... 41

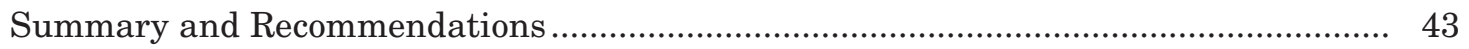




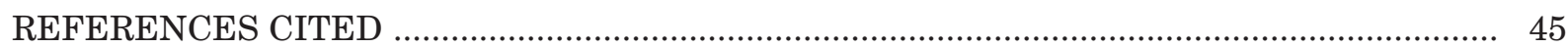

APPENDIX A: Analysis of Ceramic Vessel Sherds ................................................................... 47

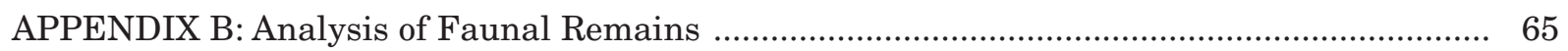




\section{LIST OF FIGURES}

1.1. Project location map

2

2.1. Location of the boat ramp project area in relation to a historic map of Velasco ................ 4

2.2. Closeup view of structures and lots in Block 14 of the Old Velasco townsite .................... 9

2.3. Overlay map showing structures of Old Velasco, the boundaries of the boat ramp project area, and the modern Brazos River ship channel

3.1. Project location and previous archeological investigation areas shown on a 2004 aerial photograph 15

3.2. Project area map showing locations of gradall and trackhoe trenches 17

3.3. Detailed map of the southern portion of the project area showing trench locations and archeological features

3.4. View of the southern portion of the project area, looking west

3.5. View of the block excavation formed by contiguous gradall trenches, looking eastward down Trench 17

4.1. Feature 1A, a burned zone exposed in the east wall of Trackhoe Trench 1 ..................... 26

4.2. Photographs of wooden post Feature 18A ................................................................. 29

4.3. Examples of identified transfer-printed ceramics ............................................................. 33

4.4. Decorative ceramic tobacco pipe fragments ................................................................. 37

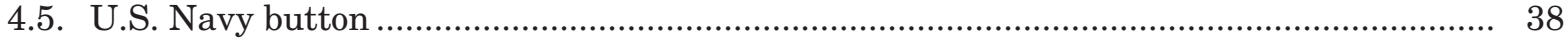

B.1. Cut surface of a Bos femur from Feature 25A .............................................................. 69

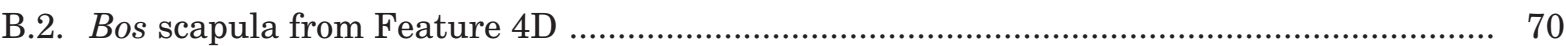

B.3. Probably Bos rib from Feature 4D ............................................................................. 72 


\section{LIST OF TABLES}

2.1. Historical timeline of Old Velasco

2.2. Building history of Block 14 of the Old Velasco townsite ................................................. 10

3.1. Summary of trench data, cultural features, and artifacts .............................................. 16

4.1. Summary of recovered artifacts by function, type, and provenience ............................... 24

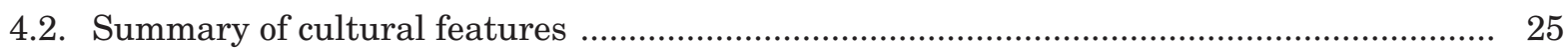

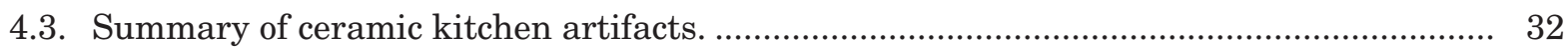

4.4. Diversity of ceramics vessel forms by ware and decorative type ...................................... 34

4.5. Container glass by provenience and color ...................................................................... 35

4.6. Summary of animal bones by feature association ........................................................ 36

5.1. Comparison of bone attributes represented in bone pit Features $4 \mathrm{~B}, 4 \mathrm{C}$, and $4 \mathrm{D} \ldots \ldots \ldots \ldots . . .42$

A.1. Identification of individual ceramic sherds ................................................................... 53

A.2. Summary of ceramic ware types and decorations ........................................................ 61

A.3. Identification of tranfer-printed ceramic patterns ................................................... 62

B.1. Taxa recovered by number of identified specimens and minimum

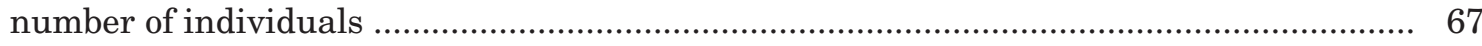

B.2. Taxa recovered by number of identified specimens and by feature association ................ 68

B.3. Taxa recovered by minimum number of individuals and by feature association ............... 69

B.4. Bos sp. and Bos sp.-sized cut bone by feature ............................................................... 72

B.5. Attributes for animal bones recovered from Old Velasco, 41BO125 ................................ 73 


\begin{abstract}
In February 2006 Prewitt and Associates, Inc., conducted an archeological survey of a 5.5-acre property slated for development as a boat ramp and parking lot by the Village of Surfside Beach in Brazoria County, Texas. The property is at the southern end of the Village of Surfside Beach, between City Hall and the U.S. Coast Guard station. The tract overlaps with the western edge of the townsite of Old Velasco (41BO125), which was a prominent port city at the mouth of the Brazos River from the 1820s through 1875. Excavation of 25 trenches revealed historic artifacts associated with Old Velasco in the southern portion of the project area, but no remains were found over the northern three-quarters of the property. Most of the culture-bearing deposits were extensively disturbed and covered with a thick layer of artificial fill. Three bone clusters found in one trench probably represent intact dump features from late-nineteenth-century Velasco. Due to the disturbed nature of the deposits, no further archeological work is recommended.
\end{abstract}




\section{CURATION}

The records generated and artifacts collected during this project will be submitted for permanent curation to the Texas Archeological Research Laboratory, J. J. Pickle Research Campus, The University of Texas at Austin. 


\section{ACKNOWLEDGMENTS}

Prewitt and Associates, Inc. (PAI) must thank many groups and individuals for their roles in this project. Thanks go first to the Village of Surfside Beach for their assistance in helping us complete this archeological project. City Secretary Kelly Hamby helped us with all of the project planning and coordinated our work with Mayor Larry Davison. Ms. Hamby's efficiency and help are greatly appreciated. John D. Mercer \& Associates, Inc. (Edna, Texas) is doing the engineering and design of the boat ramp for Surfside, and John Mercer was responsible for getting PAI involved in this archeological investigation.

The Brazosport Archeological Society (BAS) played a very active role in this project. BAS members were extremely helpful in providing background information on the boat ramp area before we began our work, they assisted us while in the field, and they helped out in the artifact analysis and reporting. The BAS assisted PAI during the original archeological investigations at Velasco in 1992 and 1993, and several members are particularly knowledgeable about the history of Velasco and the material remains that may be found there. Johnney and Sandra Pollan, James Smith, and Chris Kneupper visited our field investigations and provided helpful information. Johnney and Sandra helped PAI throughout this project, and provided us with a great deal of useful historical information pertaining to Old Velasco to help us understand what to expect in our boat ramp project area. James Smith has conducted historical research on many of the lots in the Old Velasco Townsite, and he provided us with detailed information on Lot 14, which is where the southern end of the boat ramp property is now located. BAS member Charlie Gordy assisted PAI during all of our field investigations and used his metal detector to investigate our trenches. He was a great help to us.

Prior to our field investigations, Kevin Miller of SWCA Environmental Consultants provided us with information on their recent archeological survey project in the Velasco and Quintana areas. The Brazoria County Precinct 1 Road and Bridge department provided a gradall operated by Robert Akerstrom. Velasco Drainage District Supervisor Roney Bohan allowed us to use the department's trackhoe, which was operated by Bill Drenner.

In the analysis phase, Johnney and Sandra organized and directed the analysis of the ceramic artifacts by the BAS, which is included as an appendix to this report. Brian Shaffer, an independent consultant, conducted the analysis of faunal remains and the results of his work also are included as an appendix to this report.

Thanks to Nichole Minnichbach, the U.S. Army Corps of Engineers, Galveston District, archeologist who served as the project reviewer for this project. Ed Baker reviewed the draft report for the Texas Historical Commission.

Doug Boyd of Prewitt and Associates, Inc., served as the principal investigator, and Jennifer McWilliams was the project archeologist. Elaine Robbins edited this report, and Sandy Hannum and Brian Wootan produced the figures. 



\section{INTRODUCTION}

In February 2006, Prewitt and Associates, Inc. (PAI), conducted an intensive archeological survey of the proposed boat ramp and parking lot property in the Village of Surfside Beach in Brazoria County, Texas. This archeological survey is required under authority of Section 106 of the National Historic Preservation Act and the Texas Antiquities Code. The archeological investigations are under the jurisdiction of the U.S. Army Corps of Engineers (USACE), Galveston District, and the Texas Historical Commission (THC). Surfside Beach has submitted an application to construct this project to the Galveston Corps, and it is assigned Permit No. 23586(01). The archeological investigations reported herein were done in accordance with a scope of work approved by the USACE and THC.

The project area property is at the mouth of the Brazos River, at the southern end of Surfside Beach. The Village of Surfside Beach owns the 5.5 -acre property, which is west of the City Hall and east of the U.S. Coast Guard station. Surfside Beach plans to build a boat ramp facility on the property, and the Coast Guard water inlet at the southwest corner of the property will be used for boat access. The engineering firm of John D. Mercer and Associates, Inc., is planning the project for Surfside Beach. They provided detailed construction plans to PAI to use in preparing the archeological investigations. Figure 1 shows the configuration of the proposed boat ramp property overlain onto a 2004 aerial photograph of the area.

The $850 \times 280 \mathrm{ft}$ (5.5 acres) boat ramp project area is within the Townsite of Old Velasco (ca. 1830-1875), a well-known historical and archeological site that has been designated as 41BO125. This site encompasses most of the southern portion of the modern town of Surfside Beach. Previous archeological and historical investigations at Old Velasco were conducted by the Brazosport Archeological Society (BAS) in 1991 (Pollan et al. 1996; Black and Freeman 1998), by PAI in 1992-1993 (Earls et al. 1996:39-75), and by the Cradle of Texas Conservancy and BAS since 1996. The boat ramp project area is close to the previously investigated areas, and all of the cultural remains discussed in this report relate to the historic townsite. 


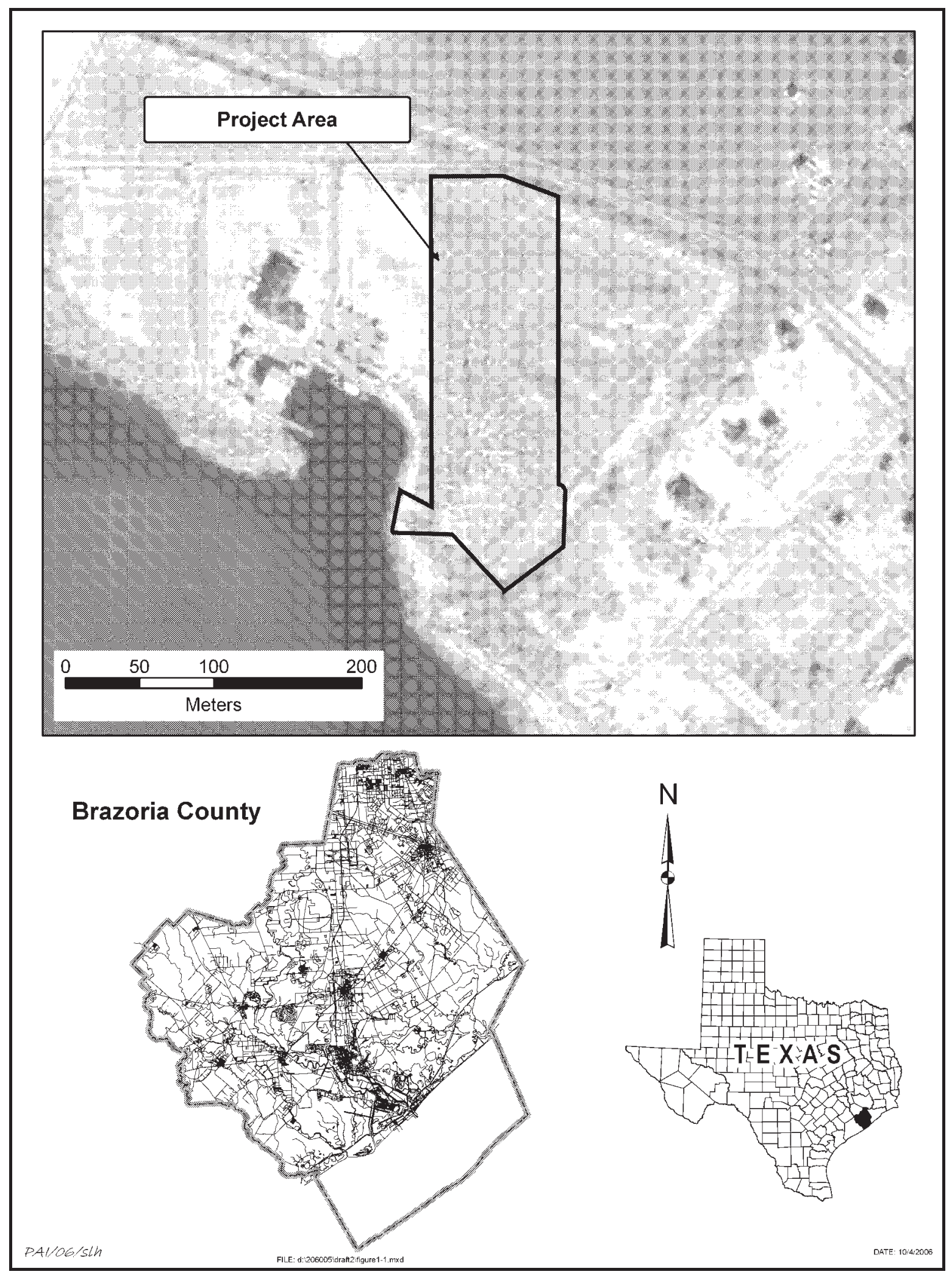

Figure 1.1. Project location map. Location of the proposed Surfside Beach boat ramp property near the U.S. Coast Guard station at Surfside Beach. John D. Mercer and Associates provided the map of the proposed facility, and the 2004 aerial photograph was obtained from the Texas Natural Resources Information System, Austin. 


\section{HISTORICAL AND ARCHEOLOGICAL OVERVIEW OF OLD VELASCO AND TOWNSITE BLOCK 14}

Some discussion is necessary in order to place PAI's archeological investigations into the appropriate historical and archeological perspectives. Because substantial historical and archeological data have been compiled previously (see Earls et al. 1996), this chapter provides only a brief historical overview of the settlement of Old Velasco and a short summary of the archeological investigations that have occurred there. In addition, more detailed information is provided on the building history of Block 14 of Old Velasco because the remains discovered in the archeological investigation of the Surfside boat ramp property can be linked to this specific block in the historic townsite.

\section{OLD VELASCO HISTORY}

Situated at the mouth of the Brazos River, Velasco was a prominent commercial port during the Mexican (1821-1836) and Republic of Texas (1836-1845) periods and even into early statehood years (Figure 2.1). Initial colonization at this location dates to the 1820 s, and the original Velasco townsite was settled before 1830, when Texas was part of Mexico (Table 2.1). The Mexican government established a customs house there in 1830 and built a small fort in 1831. In 1832, the town was the scene of the Battle of Velasco, a brief skirmish between Mexican soldiers and Texian citizens. Although itself a relatively unimportant event, the clash was a precursor to the rebellion that led to Texas independence. The Mexican Army abandoned the fort on July 29, 1832, and the Velasco townsite was platted shortly after on March 22, 1837 (Texas State Historical Association 2001; Weir 2001).
The settlement at Velasco prospered economically because it was a major port for goods coming into and out of the many large plantations located along the lower Brazos River. Velasco was an important hub during the Republic of Texas period and even served as the new republic's first seat of government for a brief period in 1836 (Myers 1996:49). Confederate forces occupied the port town during the Civil War, and many Velasco citizens moved further inland. Velasco was plagued by numerous hurricanes, the most severe being in 1866,1867 , 1871, 1875, and 1886. By most accounts, the hurricanes of 1871 and 1875 essentially wiped out the town of Old Velasco. They destroyed most of the settlement, and the majority of the survivors moved inland several miles to an area that became known as New Velasco, and this townsite was officially platted in 1891 . Only a few people continued to live in Old Velasco after 1875, until the 1886 hurricane effectively destroyed whatever remained of the town.

It is notable that historians have sometimes been confused about which Velasco historic records are referring to. For all practical purposes, Old Velasco ceased to exist as a town by about 1870 (Myers 1996:62). Any references to people living in Velasco after 1870, and certainly after 1875 , almost certainly refer to the settlement at New Velasco. New Velasco became incorporated with the modern town of Freeport in 1957 (Weir 2001). The resort community of Surfside sprang up in and near the Old Velasco townsite in the 1940s, and it grew into the modern town of Surfside Beach (Kleiner 2001).

For more detailed information on the history of Velasco, the reader is referred to Bryan (1965), Fox et al. 1981), Kleiner (2001), Myers 


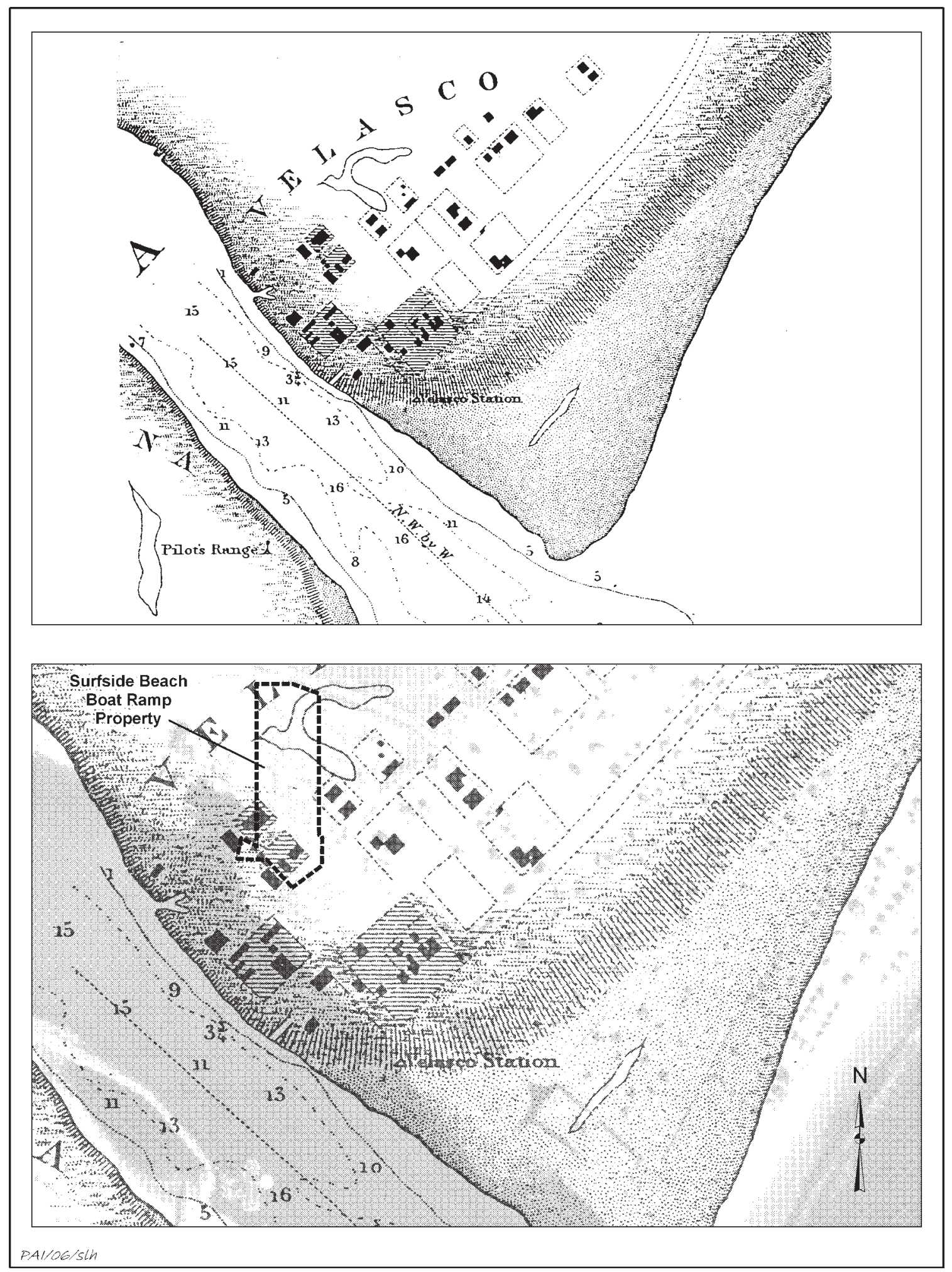

Figure 2.1. Location of the boat ramp project area in relation to a historic map of Velasco. The top map is a portion of "Preliminary Chart of Entrance to Brazos River, Texas." This map dates to 1858 and is from Bache (1858), but it shows topography and building locations as of 1852 (see Earls et al. [1996:65, Figure 133). The bottom map shows the boat ramp property overlain onto the 1858 Velasco map and the modern aerial photograph. 
Table 2.1. Historical timeline of Old Velasco*

\begin{tabular}{|c|c|c|}
\hline Year & Date & Event \\
\hline$\overline{1821}$ & December & $\begin{array}{l}\text { Eighteen immigrant recruits from the schooner the Lively arrive at the mouth } \\
\text { of the Brazos River, although they were supposed to have met Stephen F. } \\
\text { Austin at the mouth of the Colorado River. Some settle in the area of what is } \\
\text { to become Old Velasco. }\end{array}$ \\
\hline 1824 & August 24 & $\begin{array}{l}\text { Asa Mitchell was officially grants his labor of land and builds his home, which } \\
\text { probably includes an inn and general store. }\end{array}$ \\
\hline ca. 1826 & & Mitchell establishes salt works in the area. \\
\hline 1830 & & $\begin{array}{l}\text { The earliest evidence of an official Mexican presence in Velasco is a customs } \\
\text { checkpoint. Asa Mitchell is commissioned to serve as a boarding officer } \\
\text { sometime before November } 2,1830 .\end{array}$ \\
\hline 1831 & & $\begin{array}{l}\text { William Harris Wharton settles } 6 \text { miles up from Mitchell's enclave and builds } \\
\text { Eagle Island Plantation, which becomes a social and political hub of the lower } \\
\text { Brazos River region. Branch T. Archer and Edwin Waller, outspoken } \\
\text { advocates of Texas independence, move to the area and become founders of the } \\
\text { town of Velasco. }\end{array}$ \\
\hline 1831 & March & $\begin{array}{l}\text { The Brazos Hotel is established by Captain G. B. Cotten "at the house of Mr. } \\
\text { Asa Mitchell." Also standing at this time are a pilot's house, a barracks for a } \\
\text { garrison of Mexican soldiers, the Mexican commanders quarters and office, } \\
\text { and possibly a separate building serving as the customs house. }\end{array}$ \\
\hline 1831 & $\begin{array}{l}\text { March- } \\
\text { December }\end{array}$ & A Mexican garrison is established. \\
\hline 1832 & $\begin{array}{l}\text { April 19-May } \\
15\end{array}$ & $\begin{array}{l}\text { Domingo de Ugartechea, commander of the Mexican garrison, constructs Fort } \\
\text { Velasco near the customs house. }\end{array}$ \\
\hline 1832 & June 26-29 & $\begin{array}{l}\text { The Battle of Fort Velasco is fought over a four-day period. One witness } \\
\text { observes that all but two of the buildings outside the fort are burned at the } \\
\text { beginning of the battle. One of the two unburned structures is the customs } \\
\text { house; the other is an office. The Mexican army surrenders and abandons the } \\
\text { fort on June } 29,1832 \text {. }\end{array}$ \\
\hline 1833 & March & $\begin{array}{l}\text { Sometime between June } 1832 \text { and March } 1833 \text {, Asa Mitchell and neighboring } \\
\text { landowners form a land development organization called the Velasco } \\
\text { Association to plat and promote lots in his labor on the east side of the Brazos } \\
\text { River where it spills into the Gulf. }\end{array}$ \\
\hline 1833 & April & $\begin{array}{l}\text { Fort Velasco is abandoned. The town consists of a number of shacks and a } \\
\text { two-story structure under construction. This is probably the beginning of the } \\
\text { American Hotel or Brown-Hoskins Tavern. }\end{array}$ \\
\hline $1833-1836$ & & $\begin{array}{l}\text { Accounts by Mary Austin Holley and other travelers report that "one public } \\
\text { house, two stores, four or five dwelling houses, and the ruins of an old Spanish } \\
\text { fort" are standing. }\end{array}$ \\
\hline 1833 & April-October & $\begin{array}{l}\text { A cholera epidemic sweeps the lower Brazos river region; of the } 20 \text { Velasco } \\
\text { residents, } 11 \text { contracted the disease and } 8 \text { died from it, leaving only } 12 \\
\text { residents. }\end{array}$ \\
\hline 1836 & March 2 & $\begin{array}{l}\text { Texas Independence is followed by the signing of the Treaty of Velasco on May } \\
14,1836, \text { which brings an end to the Texas Revolution. }\end{array}$ \\
\hline 1836 & & The earliest recorded sale of town lots in Velasco. \\
\hline 1863 & $\begin{array}{l}\text { May- } \\
\text { September }\end{array}$ & $\begin{array}{l}\text { President Burnet has offices in a hotel in Velasco, which serves as the ad } \\
\text { interim government and first unofficial capital of Texas before the First } \\
\text { Congress of the Texas Republic officially convenes in Columbia (now West } \\
\text { Columbia). }\end{array}$ \\
\hline 1837 & June 5 & The town of Velasco is incorporated. \\
\hline 1837 & October 3 & $\begin{array}{l}\text { Velasco is struck by a formidable hurricane known as the Racer's storm, but } \\
\text { development plans continue. }\end{array}$ \\
\hline
\end{tabular}


Table 2.1, continued

\begin{tabular}{|c|c|c|}
\hline Year & Date & Event \\
\hline 1837-1839 & & $\begin{array}{l}\text { Lots found in Blocks } 10,11 \text {, and } 12 \text { are among the most frequently exchanged } \\
\text { parcels in town, due to their location along the riverfront. Additionally, these } \\
\text { lots already contained buildings. }\end{array}$ \\
\hline 1838 & January 11 & $\begin{array}{l}\text { Archer House hotel opens. Mary Austin Holley describes it as a "large 2-story } \\
\text { with gallery painted white" (Bryan 1965:53-54). She describes the ruins of } \\
\text { Fort Velasco as being in walking distance of Archer House. }\end{array}$ \\
\hline 1839 & & $\begin{array}{l}\text { A hurricane coupled with a worldwide economic depression known as the } \\
\text { Panic of } 1836 \text { (which doesn't hit Texas until 1839); contributes to the decline of } \\
\text { Velasco. }\end{array}$ \\
\hline 1839 & & $\begin{array}{l}\text { Beginning of sheriff's sales, auctions, or forfeiture of town lots, labors, even } \\
\text { leagues }\end{array}$ \\
\hline 1842 & & Hurricane \\
\hline 1845 & & $\begin{array}{l}\text { Lot sales in Velasco drop below nine lots exchanged per year, thus marking } \\
\text { the effective end of the town's growth. }\end{array}$ \\
\hline 1852 & & Town plan surveyed by United States Coastal Survey. \\
\hline 1853 & & Hurricane \\
\hline ca. 1860 & & $\begin{array}{l}\text { Confederate coastal defense plan map surveyed. Town has considerably fewer } \\
\text { buildings than in } 1852 \text {. }\end{array}$ \\
\hline 1866 & & Hurricane \\
\hline 1867 & & Hurricane \\
\hline 1871 & & Hurricane. Two of the last remaining families leave Velasco soon after. \\
\hline 1875 & & $\begin{array}{l}\text { A hurricane hits that most accounts credit with completely destroying all } \\
\text { physical evidence of Velasco. Two families rebuild their homes. }\end{array}$ \\
\hline 1872 & & Interest in Velasco property is renewed. \\
\hline 1883 & & Beginning of interest in building jetties at mouth of Brazos. \\
\hline 1886 & & $\begin{array}{l}\text { Another hurrican hits, and the last families are relocated. New Velasco is } \\
\text { established about } 4 \text { miles upriver. }\end{array}$ \\
\hline 1889 & & Construction of jetties begins. \\
\hline 1891 & & $\begin{array}{l}\text { Surfside Beach is established by the Texas Land and Immigration Company } \\
\text { on the site of Old Velasco. The Surfside Hotel is established. }\end{array}$ \\
\hline 1911 & & $\begin{array}{l}\text { The U.S. Government purchses the property where the original Coast Guard } \\
\text { Station stood. }\end{array}$ \\
\hline 1838-1967 & & Most of the streets of Surfside Village are built. \\
\hline
\end{tabular}

* Entries taken from Bryan (1965), Earls et al. (1996:39-76), Fox (1981:65), Texas State Historical Association (2001), and Weir (2001). Some information fromn different sources is contradictory, particularly about events relating to the Battle of Velasco.

(1996), Texas State Historical Association (2001), and Weir (2001). In addition, Freeman (1998) presents a comprehensive history of Quintana, the townsite established in 1834 opposite Velasco on the southwest side of the mouth of the Brazos. 


\section{PREVIOUS ARCHEOLOGICAL INVESTIGATIONS AT OLD VELASCO}

Previous investigations at archeological site 41BO125 are summarized by Earls et al. (1996:11-14). The historical and archeological investigations were triggered by a USACE project to widen and improve the Freeport Harbor at the mouth of the Brazos River. The site was recorded initially in 1975 for the Texas A\&M Research Foundation by Ippolito and Baxter (1976:22-28), which documented a brick building foundation and cistern within a oneblock area of Surfside but erroneously concluded that this was the site of the Mexican Fort Velasco. This work was carried out in the lot immediately east of the open lot called Monument Square.

The Center for Archaeological Research (CAR) at the University of Texas at San Antonio conducted a second phase of investigation on the Freeport Harbor project in 1980. Fox et al. (1981) reported detailed historical research pertaining to the early Velasco townsite, followed by archeological survey with limited testing. This research indicated that Monument Square, the open town lot shown on many nineteenth-century maps, is the most likely location of the Mexican fort (see Fox et al. 1981:Figures 5-8). The CAR test excavations were done in the vicinity of the intersection of the modern Avenue C and 14th Street and included units in Monument Square and in the property to the east. This work revealed that most of the original ground surface of Old Velasco was extensively disturbed, but relatively intact deposits were found near the clump of salt cedars in Monument Square. In addition, nineteenth-century artifacts were found in association with the intact brick building foundation and cistern east of Monument Square (i.e., the features recorded by Ippolito and Baxter [1976]).

In 1990 parts of the Confederate fortifications at the mouth of the Brazos were exposed by erosion. James L. Smith of the Brazosport Archeological Society modified the site records for 41BO125 to include the Confederate fortifications, but these remains are not in close proximity to the current PAI project area.

Beginning in 1991, the Brazosport Archeological Society (BAS) began salvaging artifacts from deposits in Old Velasco and Quintana that were disturbed by USACE activities along
Freeport Harbor. Their work has resulted in the acquisition of extensive collections of early-nineteenth-century artifacts from these townsites, which are housed at the Brazosport Museum of Natural Science in Clute. The collections of nineteenth-century ceramics have been researched, and PAI and BAS produced two illustrated catalogs of the transfer-printed wares for the USACE (Blake and Freeman 1998; Pollan et al. 1996).

The most comprehensive archeological investigation, conducted by PAI archeologists and historians in 1992-1993, took place in the southern edge of Old Velasco in areas to be disturbed by the USACE's Freeport Harbor navigation project. Myers (1996) presents a detailed history of Old Velasco, concentrating on the southernmost blocks and lots in the original townsite. The archeological investigations, reported by Earls et al. (1996:22, 77, Table 7), documented 476 features. Most were postholes, pits, or depressions, and these were generally disturbed and often contained mixed artifact assemblages from various time periods. PAI archeologists did find and investigate eight "key structural features" including brick chimney or structure foundations, brick cisterns, privies, and wells. These features had considerable archeological research potential because they contained associated artifact assemblages and could be linked to specific lots and activities by various individuals (see Earls et al. 1996:291-349).

The Cradle of Texas Conservancy (CTC) began conducting archeological investigations at Old Velasco in 1996, and their work is continuing today (James Smith, personal communication 2006). CTC, a land trust founded in 1980 to promote outdoor recreation and site preservation in Brazoria County (Texas Land Trust Council 2006), has acquired some property in Surfside, and one of the lots contains archeological remains of Old Velasco. Members of the CTC and BAS have done extensive hand excavations on the brick building foundation and cistern located southeast of Monument Square. These investigations are ongoing, and no results have been published yet.

Most recently, archeologists from SWCA Environmental Consultants conducted trenching along the Freeport LNG route through the southwestern portion of Surfside (Lawrence and Miller 2005). Their investigations included trackhoe trenching along the proposed Freeport 
LNG pipeline route. Three of the trenches were located within 41BO125 and immediately east of the boat ramp property (Lawrence and Miller 2005:Figure 6.4). The trenches (designated V1 to V3) were located in a saturated low-lying area, but excavations extended as deep as $180 \mathrm{~cm}$. The trenches revealed clay loam and clay layers, some of which were disturbed, over a sandy clay layer with scattered mussel shells at 70-80 cm. The ancient basal clay was encountered at 120 $\mathrm{cm}$, and the water table seeped in and filled the trenches up to about $50-80 \mathrm{~cm}$ below surface. The trenches and backdirt were inspected and scanned with metal detectors, but no cultural materials were found (Lawrence and Miller 2005:6-6 to 6-10).

\section{BLOCK 14 BUILDING HISTORY}

The historical research and map comparison revealed that the southern end of the proposed boat ramp is located on the site of Block 14 of the Old Velasco townsite. Because of the nature of the archeological remains found in the southern end of the project area, some additional historical discussion of this area is necessary. On the 1847 plat of Velasco, Block 14 appears to the east of First Street and west of Second Street, with Customs Street to the south and Salt Street to the north (see Figure 2.1). Block 14 was one block east of the river, with Front Street paralleling the river (Figure 2.2). Monument Square lies immediately south of Block 14 .
PAI's 1992-1993 investigations focused on Blocks 10, 11 and 12, which fall immediately west and southwest of Block 14. The block is divided into 12 lots, as were the majority of the blocks with the exception of those along Front and Gulf Streets.

Bache's 1858 map shows five large structures and two smaller structures on Block 14 . On this map, Lots 1-3 and 8-11 are improved. Title information for Block 14 lists a customs house (Lot 1), the Brutus Buroughs house (Lot 2 ), the Stacey B. Lewis house (Lot 3), and a warehouse (Lot 10) (Table 2.2). An additional building may have been present on Lot 9 .

In order to place the boat ramp project area in the context of Old Velasco, an overlay of historic and modern maps was created (Figure 2.3). It is important to understand that there could easily be as much as 20 to $50 \mathrm{ft}$ of error when rectifying these maps due to scales involved. However, when these maps are overlain, the boat ramp proposed for the southern end of the project area falls into an area once occupied by two homes (probably those of Brutus Buroughs ca. 1838 and Stacey B. Lewis ca. 1839) and two outbuildings on Lot 11, which is shown to be unimproved. The proposed project also clips the southwestern side of what was the C. P. Green \& co./ John Sharp \& Co. Warehouse, ca. 1836 (see Table 2.2). The modern jetty covers the area once occupied by the old customs house. The 1858 map shows no structures in the area that now comprises the northern two-thirds of the project area. 


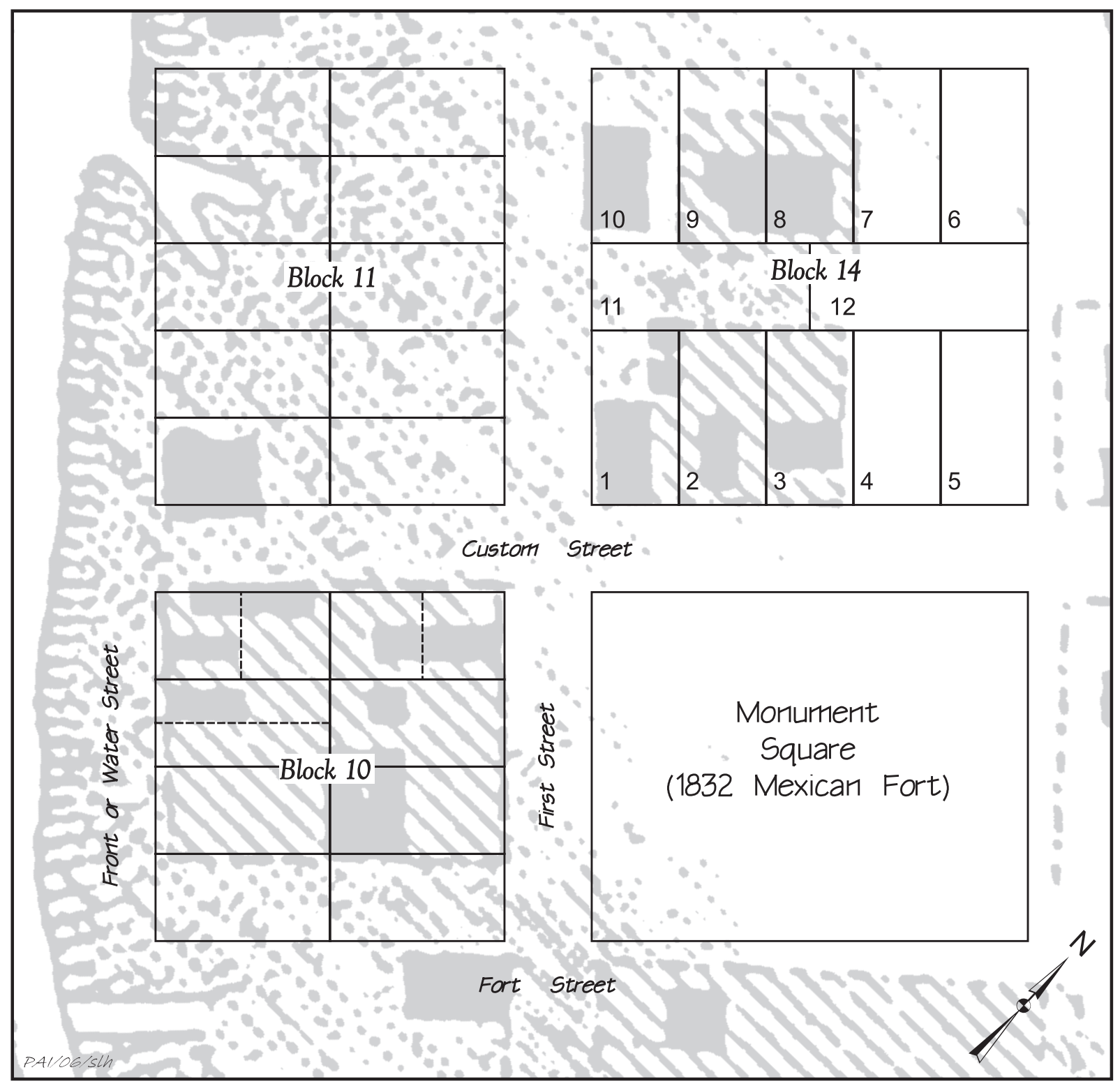

Figure 2.2. Closeup view of structures and lots in Block 14 of the Old Velasco townsite. Structures and fence lines are from the 1858 map by Bache (1858), and the blocks, lots, and streets are from Earls et al. (1996:Figure 15). Figure compiled in consultation with James L. Smith, Brazosport Archeological Society. 
Table 2.2. Building history of Block 14 of the Old Velasco Townsite

Table compiled by James L. Smith, Brazosport Archeological Society

Block 14, Lot 1

Customs House, ca. 1838

Chain of Title

1839 Lot donated to Republic of Texas

25 Aug 1857 L. B. Grissom sold property to John H. Herndon $\$ 400$

Customs House and Lot 1 donated to the Republic of Texas by Captain Jeremiah Brown. L. B. Grissom sold lot in 1857 with no mention of improvements

\section{Block 14, Lot 2 \\ Brutus Burroughs House, ca. 1838}

Chain of Title

28 Feb 1838 Thomas J. Green to Brutus Burroughs

8 March 1843 Sheriff William McMaster to Francis J. Haskins

29 July 1843 Francis J. Haskins to Robert F. Clement

3 Nov 1849 Robert F. Clement to Christiana Clement

19 Jan 1854 Sarah J. Herndon estate of John Sharp and John W. Harris estate

of John Wharton to S. C. Lyons

23 Nov 1859 Robert F. Clement to Alexander Grissom

Thomas J. Green sold lot 2 to Brutus Burroughs for $\$ 500$ February 28, 1838. Francis J. Haskins won a suit against Burroughs and bought one house and lot at sheriff's auction for $\$ 267$. Francis J. Haskins sold the "house built by Brutus Burroughs" and lot to Robert F. Clement $\$ 650$ July 1843. Robert Clement transferred the ownership over to his wife Christiana Clement in 1849. The interest of the estates of John A. Wharton and John Sharp were transferred to Samuel C. Lyons in 1854 for $\$ 20$. This was probably not of any real value. Robert F. Clement sold Lots $2 \& 3$ with improvements to Alexander Grissom for $\$ 400$.

\section{Block 14, Lot 3 \\ Stacy B. Lewis House, ca. 1839}

Chain of Title

22 Feb 1838 Thomas J. Green to Ambrose Crane

30 March 1840 Stacy B. Lewis to Louisa Anne Crane

Sheriff Auction to Isaac C. Hoskins

5 Jan 1845 Isaac C. Hoskins to Robert F. Clement

23 Nov 1859 Robert F. Clelment to Alexander Grissom

Thomas J. Green sold Lot 3 for $\$ 400$ to Ambrose Crane. Gap in ownership as Stacy B. Lewis sold the property with "dwelling house, kitchen and other improvements" to Ambrose Crane's wife Louisa Anne in 1840 for $\$ 2000$. Isaac Hoskins bought the property at a foreclosure sale and sold it to Robert F. Clement for only $\$ 20$ with no mention of any structure on the property. Robert F. Clement sold the property to Alexander Grissom in 1859. 


\section{Block 14, Lot 9 \\ Henry Wilcox, undefined improvements, ca. 1838}

Chain of Title

9 July 1838 Henry Wilcox to John P. Black

2 Jan 1840 Estate of John P. Black to E. M. Pease

1 Oct 1840 Elisha M. Pease to Samuel C. Lyons

Henry C. Wilcox sold the property with improvements to John P. Black for $\$ 1150$ in 1838 . J. P. Black's estate was forced to sell the property at auction in Jan 1840 for $\$ 200$ to E. M. Pease. Samuel C. Lyons purchased the property from E. M. Pease Oct 1840 for $\$ 250$ "with all the buildings, improvements and appurtenances." If this is a residential house, it may be the lot Samuel C. Lyons is buried on.

\section{P. Green \& Co. /John Sharp \& Co. Warehouse, ca. 1836}

Chain of Title

Pre 1837 Velasco Association to Charles P. Green \& Co.

27 Sept 1837 C. P. Green \& Co. by Thomas J. Green to John Sharp

11 May 1839 John Sharp Mortgage to Leonard W. Groce et al

The Velasco Association sold the property to Charles P. Green \& Co. initially. C. P. Green \& Co. sold the property with improvements to John Sharp in 1837 with formal title issued by Thomas J. Green to Sharp July 10, 1839 for $\$ 2480$. Sharp later mortgages the property to Leonard W. Groce and others for a line of credit in New Orleans.

\section{Block 14, Lot 11 \\ Unimproved}

\section{Chain of Title}

23 Sept 1845 Thomas J. Green to John Geo. Bolin

Thomas J. Green after his escape from prison in Mexico went to New York City to get his book on the Meir Expedition published. During this trip, it appears he raised a little cash by selling this unimproved lot for $\$ 200$ to an unsuspecting John Geo. Bolin of New York City. 


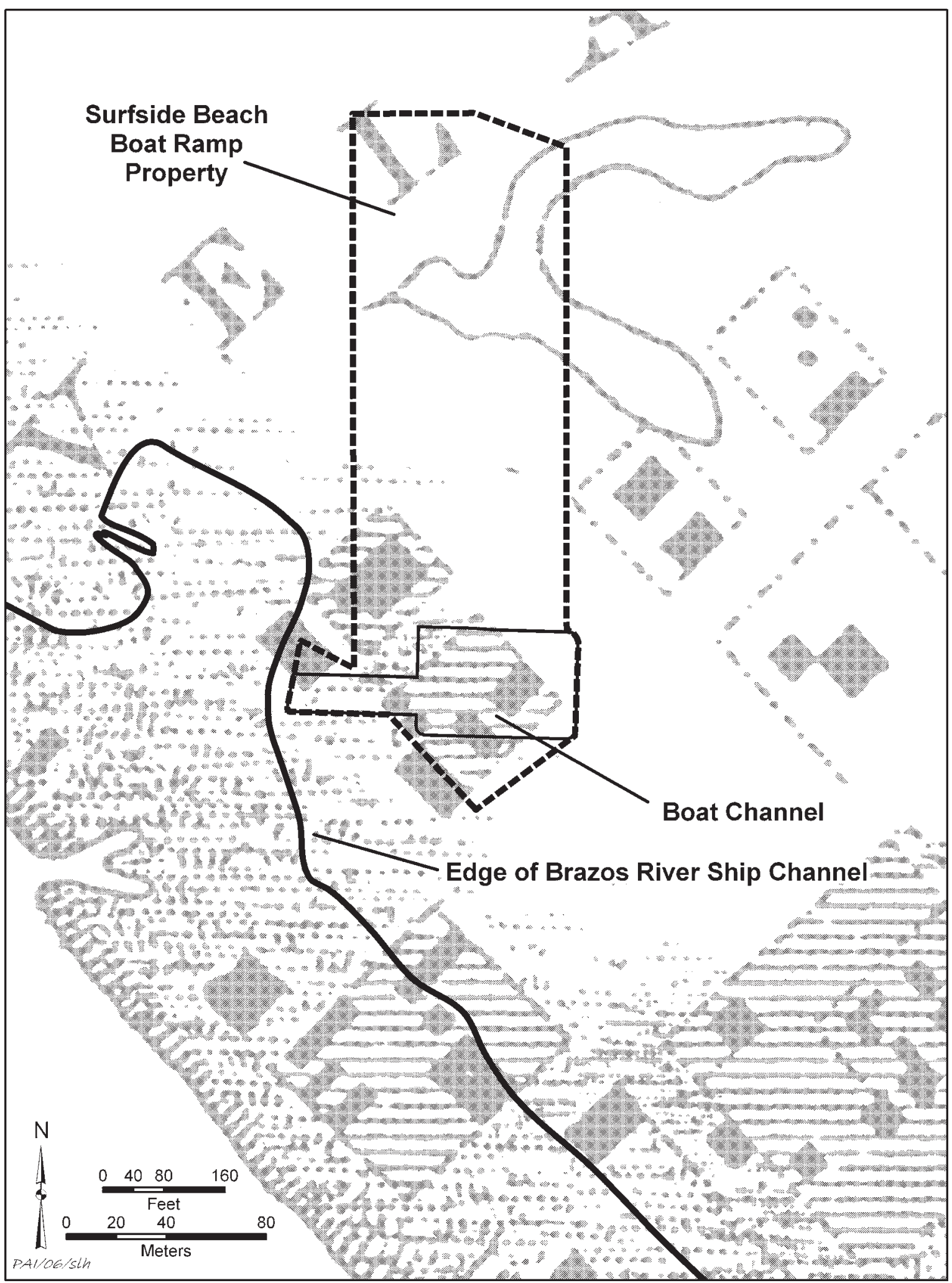

Figure 2.3. Overlay map showing structures of Old Velasco, the boundaries of the boat ramp project area, and the modern Brazos River ship channel. Historical data taken from the 1858 map by Bache (1858). Note that the overlay of the boat ramp may be as much as $50 \mathrm{ft}$ off in any direction. 


\section{METHODS OF INVESTIGATION AND WORK ACCOMPLISHED}

\section{PREFIELD INVESTIGATIONS}

In coordination with the U.S. Army Corps of Engineers (USACE), Galveston District, and the Texas Historical Commission (THC), Prewitt and Associates, Inc. (PAI), prepared a scope of work that was reviewed and approved by the USACE and submitted to THC as part of the antiquities permit application. THC issued Antiquities Permit No. 4027 for the archeological investigation of the project area. To meet the minimum state survey standards, at least 11 backhoe trenches were planned. It was determined that the potential for intact prehistoric remains was very low, and the archeological work was planned to investigate the historic townsite of Old Velasco.

Before field investigations were conducted, reports of previous investigations were reviewed (Figure 3.1) and two historic maps (Earls et al. 1996:Figures 133 and 134) were compared with modern maps of the project area. This comparison indicated that some historic structures from the old townsite had once been situated in the southern end of the boat ramp and parking lot property (see Figures 2.1, 2.2 , and 2.3). It was acknowledged, however, that the accuracy of the map comparison was probably on the order of 20 to $50 \mathrm{ft}$, so that it would not be possible to determine precise locations of former buildings.

John Mercer of John D. Mercer Associates provided helpful information on the current condition of the property and what was known about the extent of modern disturbances in the project area. Specifically, it was widely known that a considerable amount of dredge spoil from the adjacent Freeport Harbor inlet had been dumped on this property. This was done as part of the USACE's Freeport Harbor navigation project in the mid-1990s. At this time, Freeport Harbor was widened, the north jetty was removed and rebuilt, and U.S. Coast Guard station was moved and the boat inlet at the station was dug (see Earls et al. 1996:1).

PAI also reviewed the recent archeological investigations conducted by SWCA archeologists for the Freeport LNG project. This work, reported by Lawrence and Miller (2005:6-1 to 611), included investigating a proposed pipeline route through Surfside (see Chapter 2). SWCA excavated three trackhoe trenches immediately west of the Surfside boat ramp project area but did not find any cultural remains. The trench profiles for this location were described as natural, but the investigators noted some evidence of disturbances (Lawrence and Miller 2005:Figure 6.7; Table 6.1). Based on the extensive trenching done for this project, it appears likely that some of the SWCA trenches contained disturbed artificial clay fill that represents dredge spoil accumulations.

Several members of the Brazosport Archeological Society were contacted to obtain information on the project area. BAS assisted PAI during the Velasco investigations in 1992 and 1993, and several members are particularly knowledgeable about the history of Velasco and the material remains that may be found there. In particular, Johnney and Sandra Pollan and James Smith provided useful information on what to expect in the boat ramp project area. 


\section{METHODS OF ARCHEOLOGICAL INVESTIGATION}

PAI conducted field investigations between February 21 and 23, 2006 (Figure 3.1). Trenches were dug to examine the subsurface deposits. On behalf of Surfside Beach, Brazoria County Precinct 1 provided a gradall and an operator, and the Velasco Drainage District provided a trackhoe and an operator. An archeologist closely monitored the excavation of each trench.

Length, width, and depth were recorded for each trench, along with stratigraphic sediment descriptions. Selected trench profiles were photographed. Features were recorded in detail, including descriptive notes, plan maps and profiles, and photographs.

For all trenches less than $5 \mathrm{ft}$ deep, the trench bottom and walls were closely examined. Archeologists did not enter the deeper trenches, many of which were extremely unstable because of the nature and amount of dredge fill. In some trenches, there were many feet of water-saturated artificial clay sediments above the natural sand layer that was at or near the water table. As the water level fluctuated with the tide, the sand would ooze out and cause trench walls to collapse. Because of this threat, the stratigraphy of deep trenches was viewed only from the surface, and the sandy sediments constituting the old historic surface were examined as they were brought up in the machine bucket.

PAI archeologists used a Trimble XRS-PRO global positioning system to map the site, including modern features (such as fences and buildings), the locations of each trench, and selected archeological features. Also included were key mapping points used in PAI's previous investigations (Earls et al. 1996) and the Datum 3 point bronze marker used by CTC and BAS during their ongoing archeological investigations. Measured sketch maps were drawn to plot the locations of all cultural features found within each trench.

Artifacts samples were obtained from the surface, from trenches, and from features. Surface artifact sampling was random, and only diagnostic artifacts were collected. Most of the identifiable and diagnostic artifacts found in trenches were collected, and all of the artifacts (or a sizable sample) were collected from each cultural feature. When a concentration of artifacts was observed during trenching, particularly in the broad burned zone feature areas, some of the sediments were screened to recover a better sample of cultural materials. No attempts were made to collect all artifacts, and the collection policy was to collect all of the temporally diagnostic specimens (particularly ceramics and glass) and only collect a few of the less diagnostic and bulky specimens (such as brick fragment, oyster shells, and unmodified rocks). Any materials that were not collected, including probable structural debris were documented in the field notes.

\section{WORK ACCOMPLISHED AND RESULTS OF INVESTIGATIONS}

Two PAI archeologists and a BAS volunteer spent three days on the property and monitored excavation of 25 trenches, summarized in Table 3.1. As shown in Figure 3.2, the trenches were scattered out across the 5.5-acre property except for the wetland areas, which the project will not disturb. During the investigations, it became clear that nineteenth-century artifacts were present in the top of the sand layer that once formed the original ground surface, which we will refer to as the "Old Velasco surface." The goal of the trenching was to identify and examine this surface and to trench carefully into the sand layer to look for intrusive features that might be intact. Over almost all of the project area, the original sand layer was buried by a thick layer of artificial fill varying in thickness from a few $\mathrm{cm}$ to as much as $280 \mathrm{~cm}$.

The use of both the trackhoe and the gradall proved to be extremely efficient. The backhoe was used primarily at the northern end of the project area, with some exception, where archeological deposits were scarce. The trackhoe was used at the southern end of the project area, where vertical control was especially important since historic archeological deposits were both common and dense. The long, extended arm of the trackhoe was particularly useful in the south-central portion of the 5.5-acre tract, where dredge spoil reached $2.6 \mathrm{~m}$ deep.

Trenching began at the south end of the property with Trenches $1-8$. The gradall was then taken along the western boundary and moved northward. The southern portion of the project area was investigated more intensively for three reasons. First, this southern end will be extensively disturbed by the proposed boat 


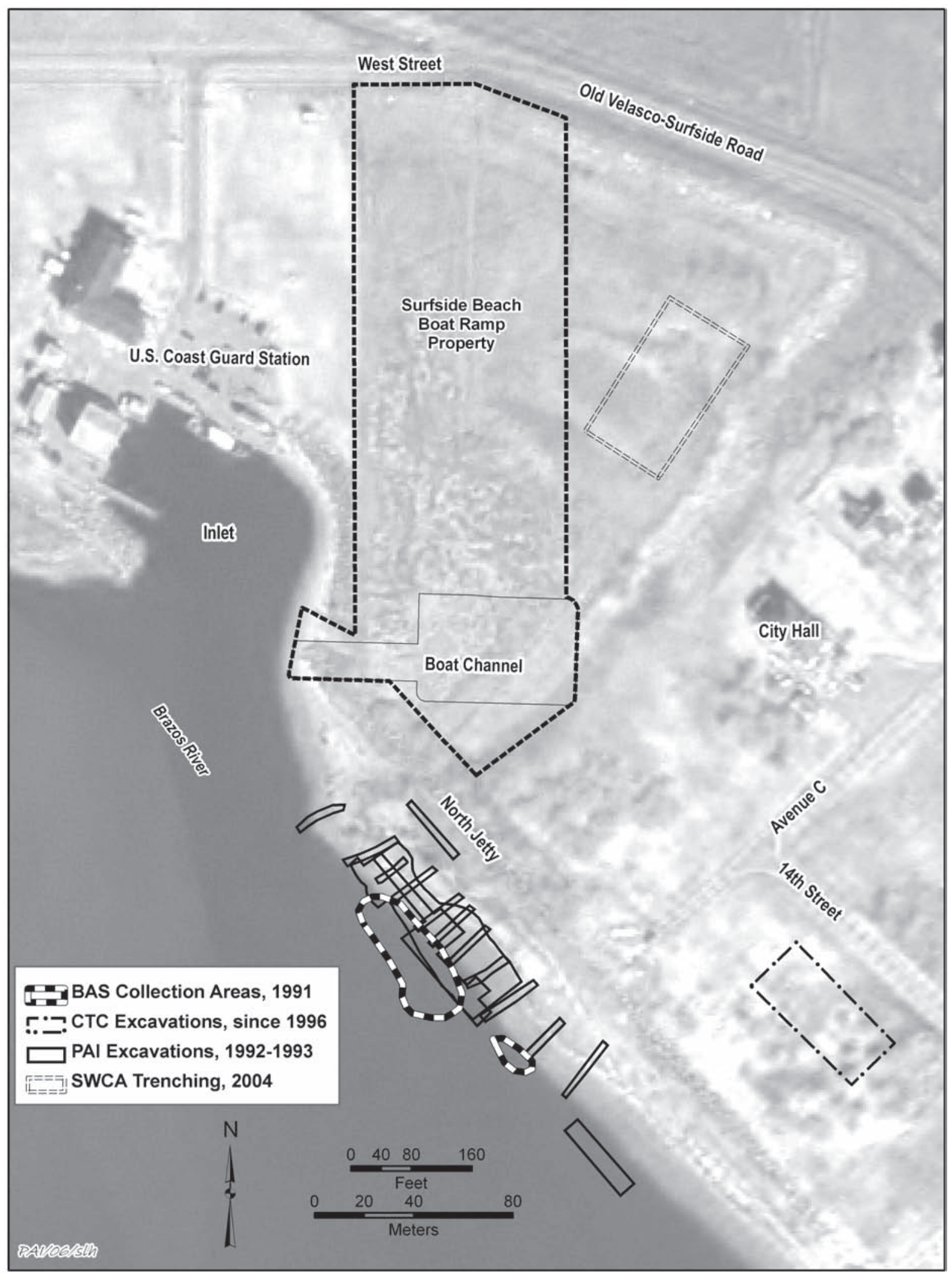

Figure 3.1. Project location and previous archeological investigation areas shown on a 2004 aerial photograph. Base photograph is from the Texas Natural Resources Information System. 
Table 3.1. Summary of trench data, cultural features, and artifacts

\begin{tabular}{|c|c|c|c|c|c|c|c|c|}
\hline Provenience & $\begin{array}{l}\text { Location } \\
\text { in } \\
\text { Project } \\
\text { Area } \\
\end{array}$ & $\begin{array}{l}\text { Length } \\
(\mathrm{m})\end{array}$ & $\begin{array}{c}\text { Width } \\
(\mathrm{m})^{*}\end{array}$ & $\begin{array}{l}\text { Maximum } \\
\text { Depth (m) }\end{array}$ & $\begin{array}{c}\text { Depth to Old } \\
\text { Velasco Surface } \\
(\mathrm{cmbs})\end{array}$ & $\begin{array}{l}\text { Features } \\
\text { Observed }\end{array}$ & $\begin{array}{l}\text { Nineteenth- } \\
\text { Century } \\
\text { Artifacts } \\
\text { Observed } \\
\end{array}$ & $\begin{array}{l}\text { Artifact } \\
\text { Sample } \\
\text { Collected }\end{array}$ \\
\hline Surface & all & - & - & - & not applicable & - & yes & yes \\
\hline $\mathrm{TT} 1$ & southern & 38.0 & 1.8 & 1.0 & $40-100$ & $1 \mathrm{~A}$ & yes & no \\
\hline TT 2 & southern & 28.0 & 1.8 & 1.6 & $60-120$ & - & yes & no \\
\hline TT 3 & southern & 28.0 & 1.8 & 170.0 & $50-100$ & $3 \mathrm{~A}$ and $3 \mathrm{~B}$ & yes & yes \\
\hline TT 4 & southern & 29.5 & 1.8 & 170.0 & $60-150$ & $\begin{array}{c}4 \mathrm{~A}, 4 \mathrm{~B}, 4 \mathrm{C} \\
\text { and } 4 \mathrm{D}\end{array}$ & yes & yes \\
\hline GT 5 & southern & 7.0 & 1.5 & 180.0 & 140 & - & yes & no \\
\hline GT 6 & southern & 8.5 & 1.5 & 200.0 & 140 & $6 \mathrm{~A}$ & yes & yes \\
\hline GT 7 & southern & 27.0 & 1.5 & 2.7 & 260 & - & no & no \\
\hline GT 8 & southern & 10.0 & 1.5 & 2.2 & 180 & - & no & no \\
\hline GT 9 & southern & 13.0 & 1.5 & 2.15 & 185 & - & no & no \\
\hline GT 10 & northern & 11.0 & 1.5 & 2.6 & 115 & - & no & no \\
\hline GT 11 & northern & 7.0 & 1.5 & 1.8 & 135 & - & no & no \\
\hline GT 12 & northern & 8.0 & 1.5 & 1.4 & 95 & - & no & no \\
\hline TT 13 & northern & 5.0 & 1.8 & 1.8 & 110 & - & no & no \\
\hline TT 14 & northern & 5.0 & 1.8 & 1.9 & not observed & - & no & no \\
\hline TT 15 & northern & 10.0 & 1.8 & 3.5 & 265 & - & no & no \\
\hline TT 16 & southern & 28.0 & 1.8 & 2.5 & 130 & $16 \mathrm{~A}$ & yes & yes \\
\hline TT 17 & southern & 15.0 & 1.8 & 0.8 & $0-40$ & - & yes & yes \\
\hline TT 18 & southern & 25.0 & 1.8 & 0.5 & $0-54$ & $18 \mathrm{~A}$ & yes & yes \\
\hline TT $19 * *$ & southern & 10.0 & 1.8 & 0.5 & $0-50$ & - & yes & yes \\
\hline $\mathrm{TT} 20 * *$ & southern & 10.0 & 1.8 & 0.5 & $0-50$ & - & yes & yes \\
\hline $\mathrm{TT} 21 * *$ & southern & 10.0 & 1.8 & 0.5 & $0-50$ & $21 \mathrm{~A}, 21 \mathrm{~B}$ & yes & yes \\
\hline TT $22 * *$ & southern & 10.0 & 1.8 & 0.5 & $0-50$ & - & yes & yes \\
\hline TT $23 * *$ & southern & 10.0 & 1.8 & 0.5 & $0-50$ & $23 \mathrm{~A}$ & yes & yes \\
\hline $\mathrm{TT} 24^{* *}$ & southern & 10.0 & 1.8 & 0.5 & $0-50$ & - & yes & yes \\
\hline TT 25 & southern & 20.0 & 1.8 & 1.0 & $50-70$ & $25 \mathrm{~A}$ & yes & yes \\
\hline
\end{tabular}

TT = Trackhoe Trench; GT = Gradall Trench

* Gradall trenches were $1.5 \mathrm{~m}$ wide and trackhoe trenches were $1.8 \mathrm{~m}$ wide.

** Trenches 19 to 24 are contiguous within a block measuring $11 \mathrm{~m}$ (east-west) by $10 \mathrm{~m}$ (north-south).

ramp project because the construction plans call for excavation of a deep boat channel running east from the Coast Guard inlet, and temporary boat slips and boat ramps will be constructed as well. Second, the historic archival records indicated that structures associated with Old Velasco, specifically Lot 14 of the original townsite, might be present in the southern end of the project area (see Figure 2.3). Finally, when cultural materials were encountered in the first trenches excavated in the southern area, but not in any of the northern trenches, it was appropriate to intensify the search in the southern end of the property. For discussion purposes, the testing results in the project area are divided into two locationsnorthern and southern.

\section{Northern Portion of the Project Area}

Seven trenches (Trenches 9-15) were dug in the northern three-quarters of the project area (see Figure 3.2). Trench profiles exposed an extremely thick layer of artificial dredge fill, between 100 and $270 \mathrm{~cm}$ thick, in all but one trench. Trench 14 was placed in a depression near a natural wetland, apparently where spoil was not piled. Though some modern and historic artifacts were mixed in the surficial artificial fill, no historic artifacts or features were observed in the sand layer in any of these trenches (see Table 3.1).

Trenches 9-15 ranged from 5 to $13 \mathrm{~m}$ long and reached depths of 1.4 to $3.5 \mathrm{~m}$ deep. 


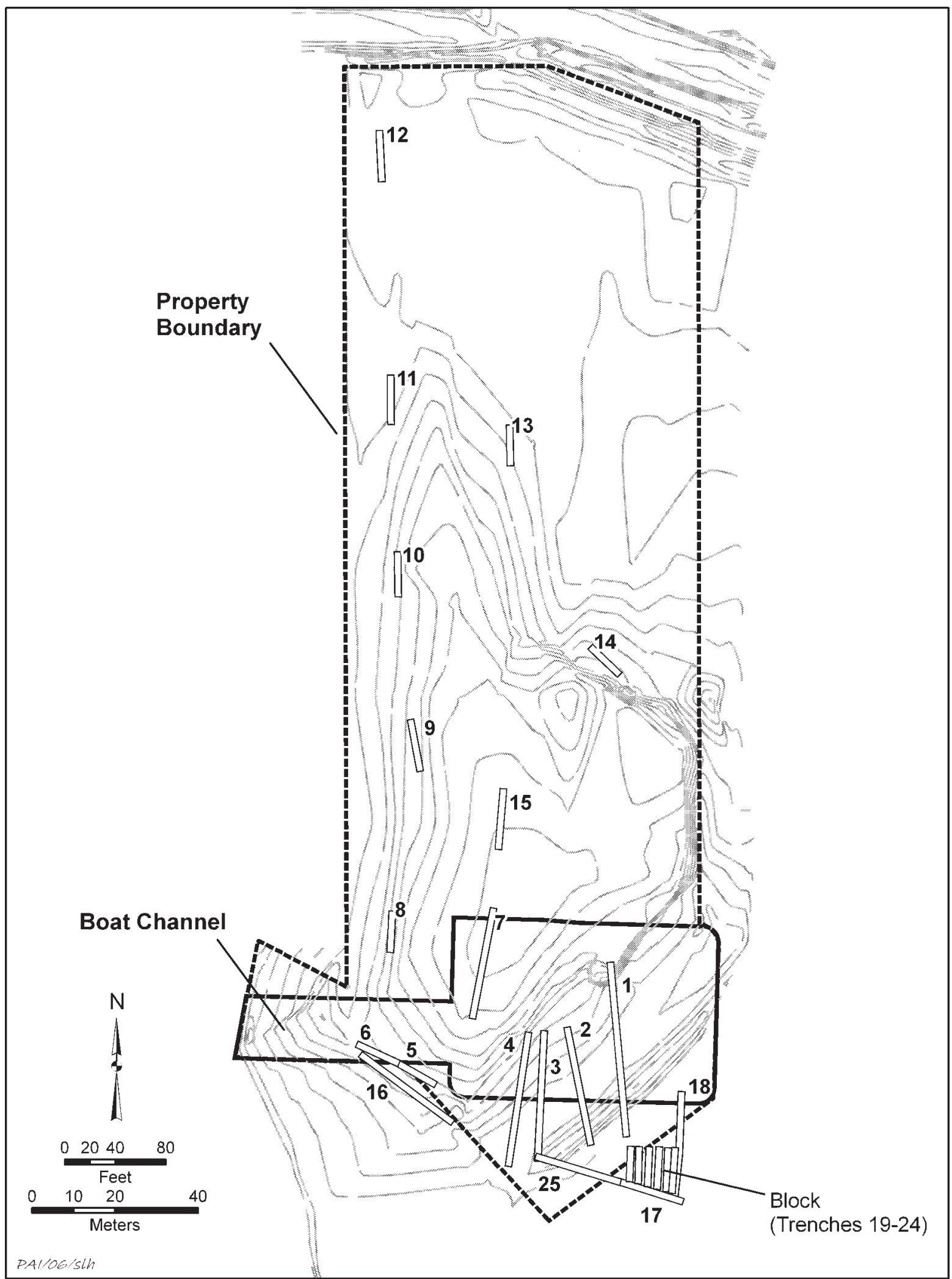

Figure 3.2. Project area map showing locations of gradall and trackhoe trenches. Site topography is from "Existing Contours" map of the Surfside Beach boat ramp by John D. Mercer and Associates, Inc. 
Trenches $9-12$ were excavated by the gradall and were $1.5 \mathrm{~m}$ wide. Trenches $13-15$ were excavated by the Trackhoe and were $1.8 \mathrm{~m}$ wide. The artificial fill was a highly mottled mixture of gray to pale gray clay or marl. The sandy, historic substrate was recorded between 0.95 and $2.65 \mathrm{~m}$ deep in Trenches 9, 11-13 and 15, but was not observed in Trenches 10 or 14 . A burned zone was noted at $1.15 \mathrm{~m}$ below surface in the profile of Trench 10, and Trench 14 lacked a sandy layer due to placement of the trench in a low-lying area.

\section{Southern Portion of the Project Area}

Eighteen trenches (Trenches 1-8 and 1625) were dug in the southern quarter of the project area (Figures 3.3 and 3.4). Of these, eight trenches (17-24) were contiguous and make up a block in the far southeastern corner of the project area (Figure 3.5). The trenches in the southern area revealed that the southwestern corner of the project area generally had less than $50 \mathrm{~cm}$ of artificial fill on top of the sand layer. Although Trenches 1-4 exposed no more than $150 \mathrm{~cm}$ of artificial fill, Trench 7 exposed $260 \mathrm{~cm}$ of fill, and Trench 8, $180 \mathrm{~cm}$. Historic and modern debris was present in the artificial layer, and many of the trenches exhibited stratified layers of different types of fill. This indicates that the dumping of dredge spoil and other sediment on this property has been an ongoing process.

Trackhoe Trenches 1-4 were placed in the southeast corner of the project area and was oriented north-south. Trackhoe Trench 1 spanned $38 \mathrm{~m}$ long and reached $1.0 \mathrm{~m}$ deep. The old Velasco sandy surface appeared at the north and south ends of the trench, ranging from ca. 45 to $90 \mathrm{~cm}$ below surface-just below a burned zone (see Feature 1A in Chapter 4). The central portion of the trench lacked the historic sandy lens as this area had apparently been dug out and was filled in with red clay. This artificial fill probably filled an old drainage ditch or cut. Trackhoe Trench 2 was placed ca. $8 \mathrm{~m}$ west of Trench 1. The trench extended $28 \mathrm{~m}$ and reached a maximum depth of $1.6 \mathrm{~m}$ after the features were removed. Thickness of the artificial fill varied from 40 to $50 \mathrm{~cm}$ in the south end of the trench to more than $1 \mathrm{~m}$ in the northern end. The sandy historic lens was exposed from 60 to $120 \mathrm{~cm}$ below surface, but no fea- tures were observed. Patches of light burned zones were observed in places, but no artifacts were present. As in Trench 1, a cut or ditch was present in the center of the trench, again filled with red clay. Trackhoe Trench 3 was placed ca. $14 \mathrm{~m}$ west of Trench 2 . The trench was $28 \mathrm{~m}$ long and reached $1.7 \mathrm{~m}$ deep. Two burned zones were recorded (see Features $3 \mathrm{~A}$ and $3 \mathrm{~B}$ below).

Trackhoe Trench 4 was placed ca. $6 \mathrm{~m}$ west of Trench 3. The trench was $29.5 \mathrm{~m}$ long and reached $1.7 \mathrm{~m}$ deep. The depth of the upper spoil fill varied. A detailed profile description of the western wall of Trench 4 at Feature 4D follows: The upper $40 \mathrm{~cm}$ exposed a pale brown sand (10YR 6/3) with light gray and brown inclusions (10YR 7/2 and 10 YR 5/3) followed by dredge spoil of brown clay (7.5YR 4/3) reaching $50 \mathrm{~cm}$ thick. Below the dredge material or spoil a brown (7.5YR 4/3) sandy clay to clay with faint yellowish brown (10YR 5/4) ferrous inclusions was exposed from 90 to $123 \mathrm{~cm}$. Finally, a grayish brown (10YR 5/2) clay extended into the bottom of the trench at $147 \mathrm{~cm}$ below surface.

Trackhoe Trench 5 and 6 were placed at the far southern end of the project area near the western corner. The two trenches were in line with one another and run along a northwestsoutheast axis following the nearby rock levee. Trench 5 was $7 \mathrm{~m}$ long and Trench 6 spanned $8.5 \mathrm{~m}$. Dredge spoil is thick here and reaches ca. $140 \mathrm{~cm}$ deep with the historic sand lens extending to the bottom of the trenches at ca. 1.8$2.0 \mathrm{~m}$. A burned zone was recorded at the western end of Trench 6 (Feature 6A).

Trackhoe Trench 7 and Backhoe Trench 8 were placed in the southwestern portion of the project area. Trench 7 spanned $27 \mathrm{~m}$ long and reached $2.7 \mathrm{~m}$ deep. The historic sandy lens was recorded $2.6 \mathrm{~m}$ below the surface. Trench 8 extended $10 \mathrm{~m}$ long and reached $2.2 \mathrm{~m}$ deep. The historic zone was reached at $1.8 \mathrm{~m}$ below the surface. No cultural remains were observed in Trenches 7 or 8 .

Trackhoe Trench 16 ran along the north side of the rock levee, parallel to Trenches 5 and 6 . The trench was $28 \mathrm{~m}$ long and reached $2.5 \mathrm{~m}$ deep. An old rock levee was exposed near the western end of the trench, and Feature $16 \mathrm{~A}$, a burned area, was exposed in the center of the trench.

Trackhoe Trenches 17-24, at the far southeastern corner of the project area, were contiguous and formed a block. These trenches 


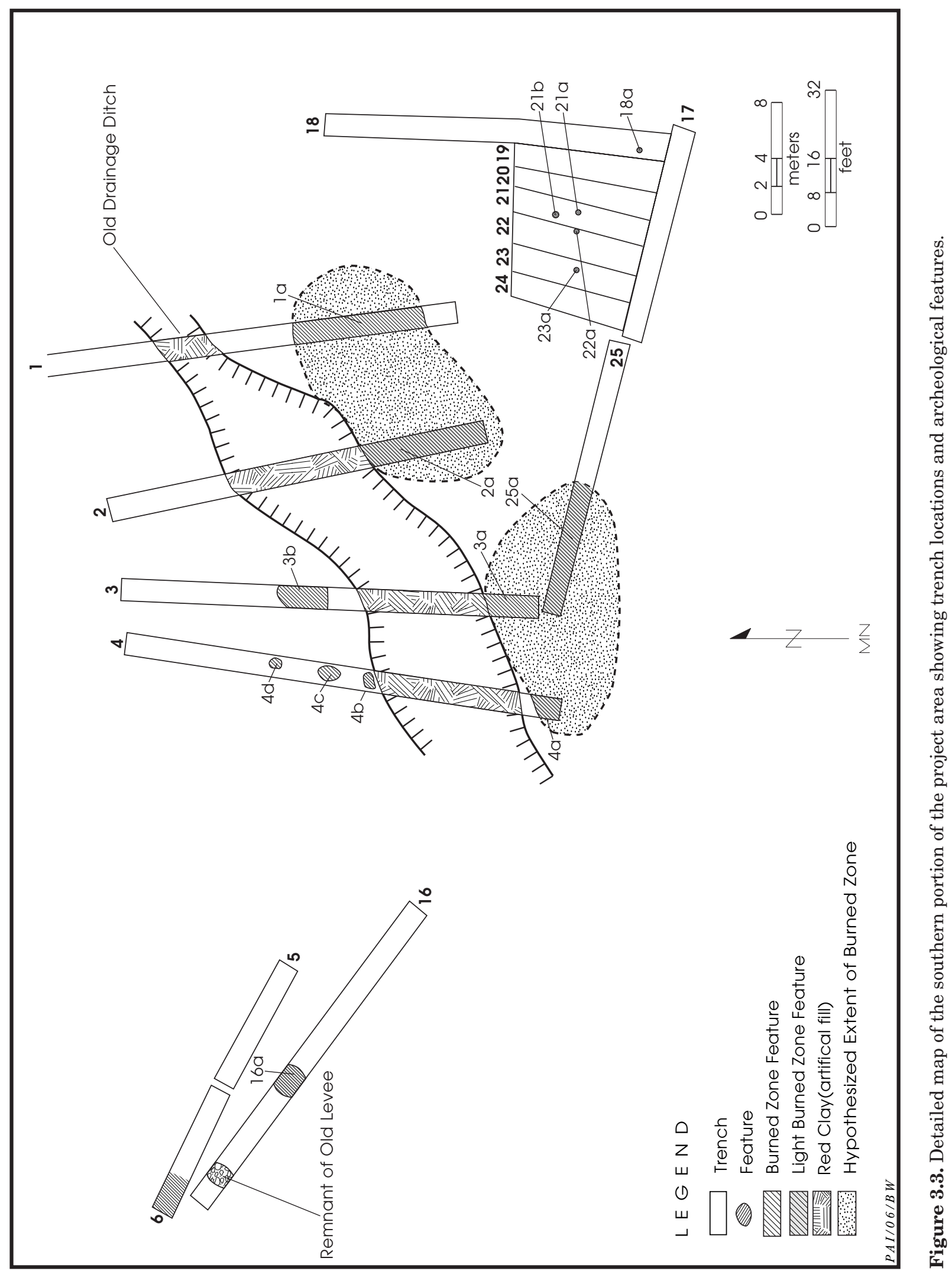




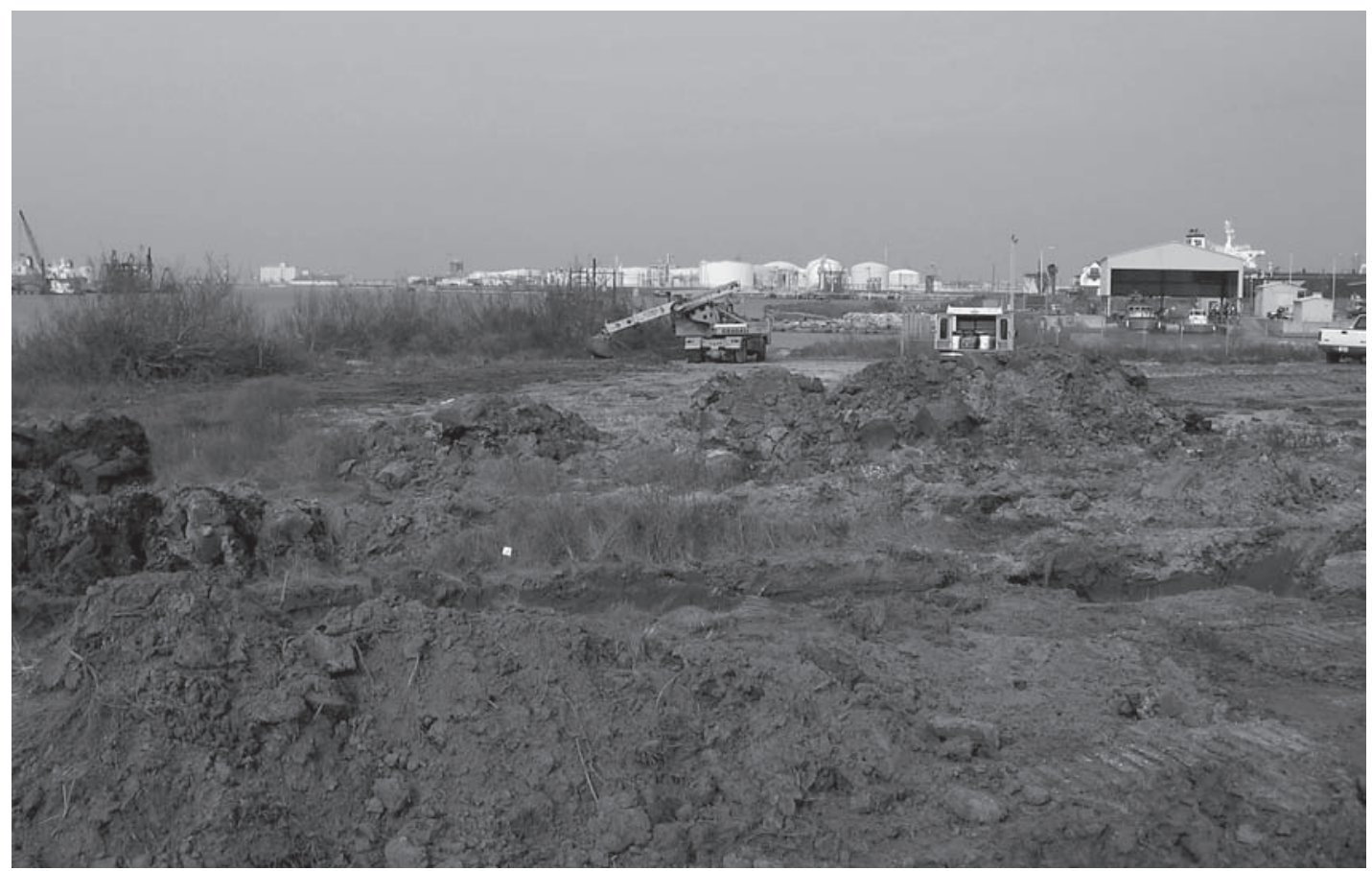

Figure 3.4. View of the southern portion of the project area, looking west. Gradall in background is backfilling Trench 5. Building at right-center is the boathouse at the U.S. Coast Guard Station.

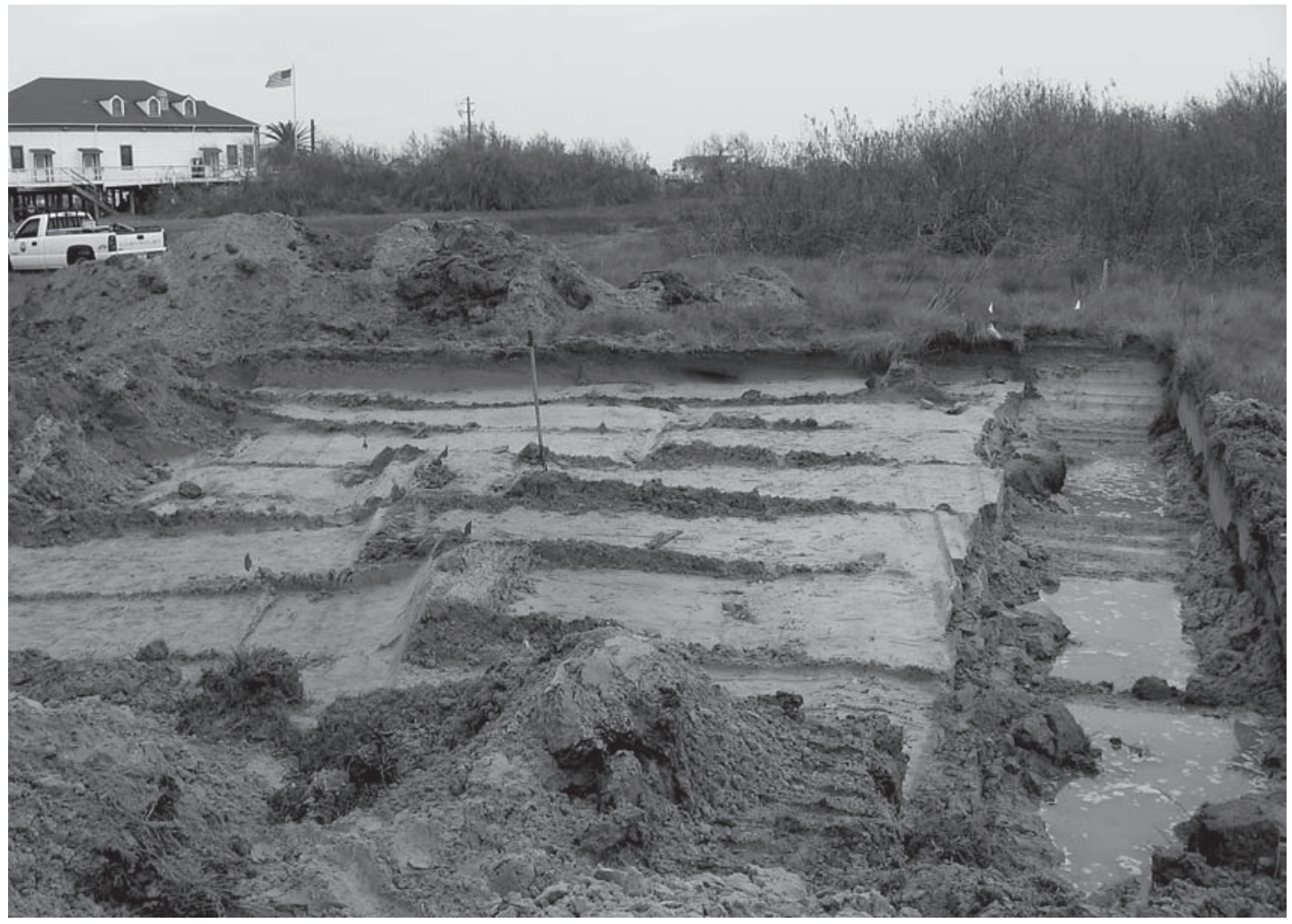

Figure 3.5. View of the block excavation formed by contiguous gradall trenches, looking eastward down Trench 17 (partially filled with water on right). Surfside Beach City Hall is in the background on the left. 
were shallow, since dredge spoil was not dumped in this area. Trenches reached only $51-70 \mathrm{~cm}$ deep. Trench 17 ran westward from a corner stake that was believed to be the corner of the project boundary. The trench was $15 \mathrm{~m}$ long and formed the southern boundary of the block. Trench 18 began at the presumed corner stake and extended northward $25 \mathrm{~m}$. Trenches 19-24 were each excavated northward from Trench 17. Four features were recorded in the block area: three posts (Features 18A, 21A and 22A) and a bone cluster (Feature 21B). Additional, smaller wooden pieces were found in the block area, but were not recorded as a feature due to displacement. Artifacts from Trenches 17 and 18 were collected and bagged separately. Artifacts collected from the block area were bagged together with the exception of artifacts found in features, which were collected and bagged separately.

Trackhoe Trench 25 was placed along the southern boundary of the project area and spanned from the south end of Trench 3 to the southwest corner of the block. The trench was $20 \mathrm{~m}$ long and reached $1.0 \mathrm{~m}$ deep. Feature 25, part of a larger burned area, was exposed in the western half of the trench. 



\section{DESCRIPTION AND INTERPRETATION OF NINETEENTH-CENTURY FEATURES AND ARTIFACTS}

Investigations for the boat ramp produced 811 artifacts, and 14 cultural features were identified (Table 4.1). Artifacts were processed and cataloged at the PAI laboratory. Bone was sent to zooarcheological consultant Brian Shaffer for analysis, while the ceramics were sent to the Brazoria County Archeological Society for analysis under the direction of Johnney Pollan and Sandra Pollan. For identification of artifacts and features, published historical and archeological references are used for comparison.

\section{FEATURES}

Fourteen cultural features were identified during trenching at 41BO125 (Table 4.2; see Figure 3.6). Of these, seven were burned zones, three were bone pit features, one was a bone cluster, and three were wooden posts. Each feature was assigned a unique designation by combining the trench number in which the feature was found and a letter designations. Features are organized by type and described below. Artifacts from each feature are listed in this section, but they are described in more detail in the Artifact section.

\section{Burned Zones}

Seven burned zones were recorded during trenching (see Table 4.1), although two or more may be exposures of a larger burned area (as described below). The burned zones all appeared as horizontally extensive lenses of charcoal, black-stained soil, and other materials that were seen and examined in plan view as the trenches were excavated and then were visible in wall profiles of the trenches immediately above the sandy historic lens. All of these features contained at least a few historic artifacts (such as glass or whiteware fragments) that could date to the nineteenth century (see Table 4.2), and many contained temporally diagnostic bottle glass (hand blown or snap-case molded) or ceramics (various transfer-printed wares were common) that were undoubtedly associated with nineteenth-century Velasco. A metal detector was used to scan the surface of these burned zones as they were encountered and to examine the trench walls after excavation. Metal artifacts were not common, but some badly corroded and unidentifiable iron objects were found in some of these features. Several of the burned zones also contained broken fragments of hand-made red bricks and oyster shells.

\section{Feature 1A}

Feature 1A was exposed at the south end of Trackhoe Trench 1 and extended over $10 \mathrm{~m}$ along the north-south oriented trench (Figure 4.1). The intense burned area was $10-\mathrm{cm}$ thick, reaching $90 \mathrm{~cm}$ deep on the north end and 45$55 \mathrm{~cm}$ deep on the south end due to variations in the ground surface. Within the feature, blackened soil with charcoal chunks, red handmade brick fragments, and numerous oyster shells. Nineteenth century artifacts were present within the feature, but were not abundant. No artifacts were collected from this feature, but the metal detector identified a few corroded iron artifacts, none of which were collected. The western extent of this feature was exposed in Trench 2. Here, a slight burn zone was noted in the southern third of the trench and may represent the outer edge of a burn pile. 


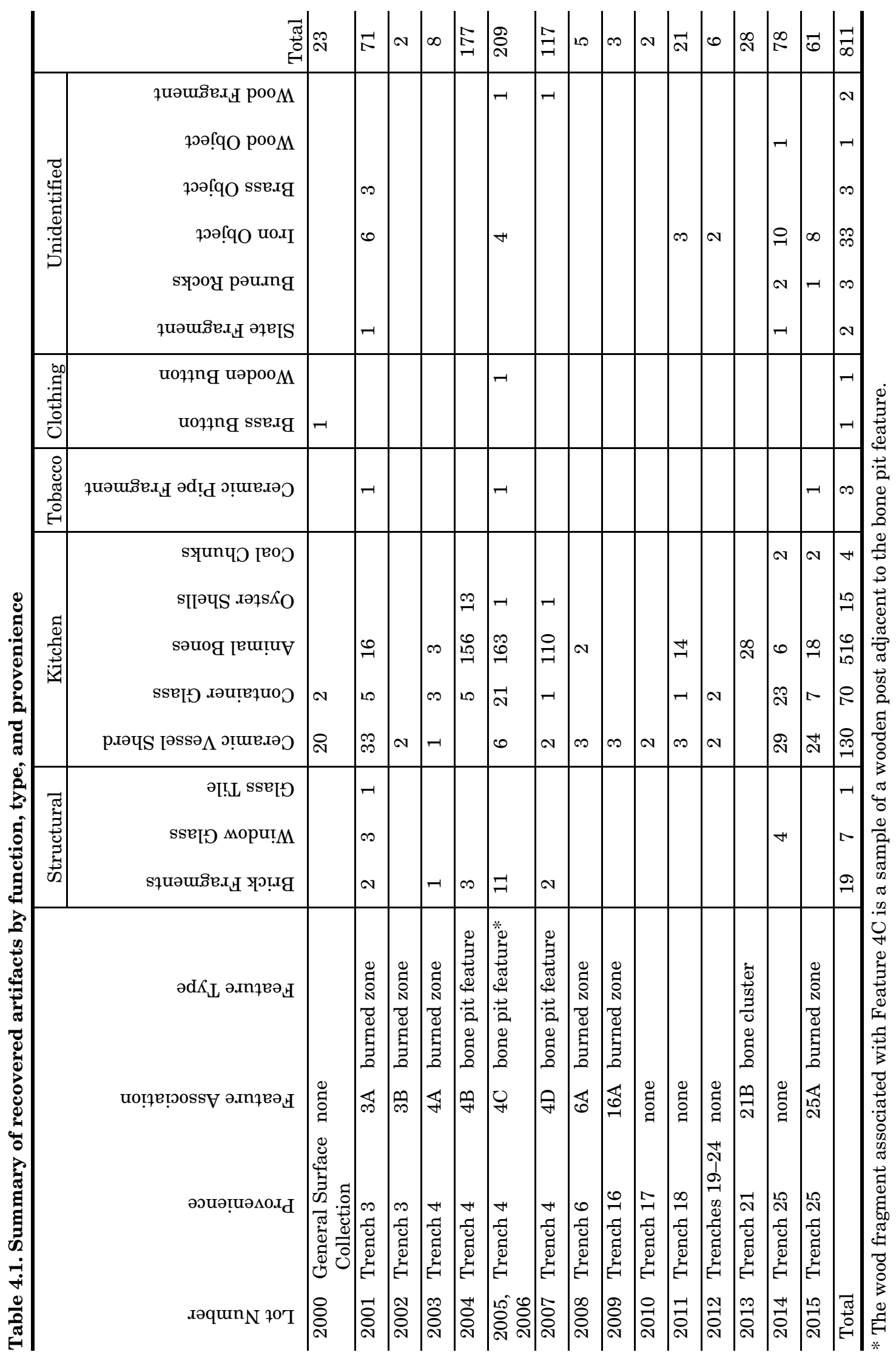


Chapter 4: Nineteenth-Century Features and Artifacts

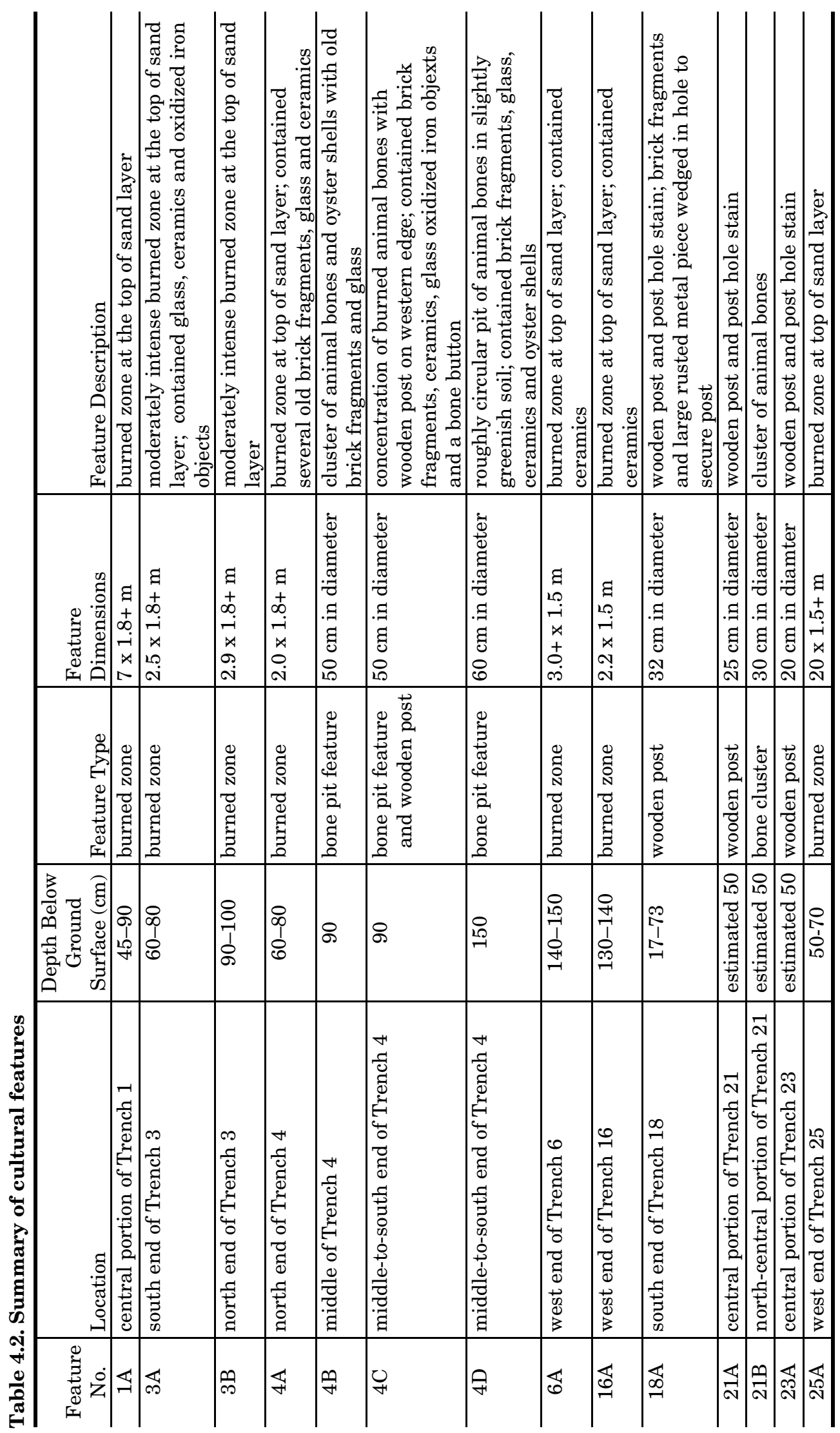




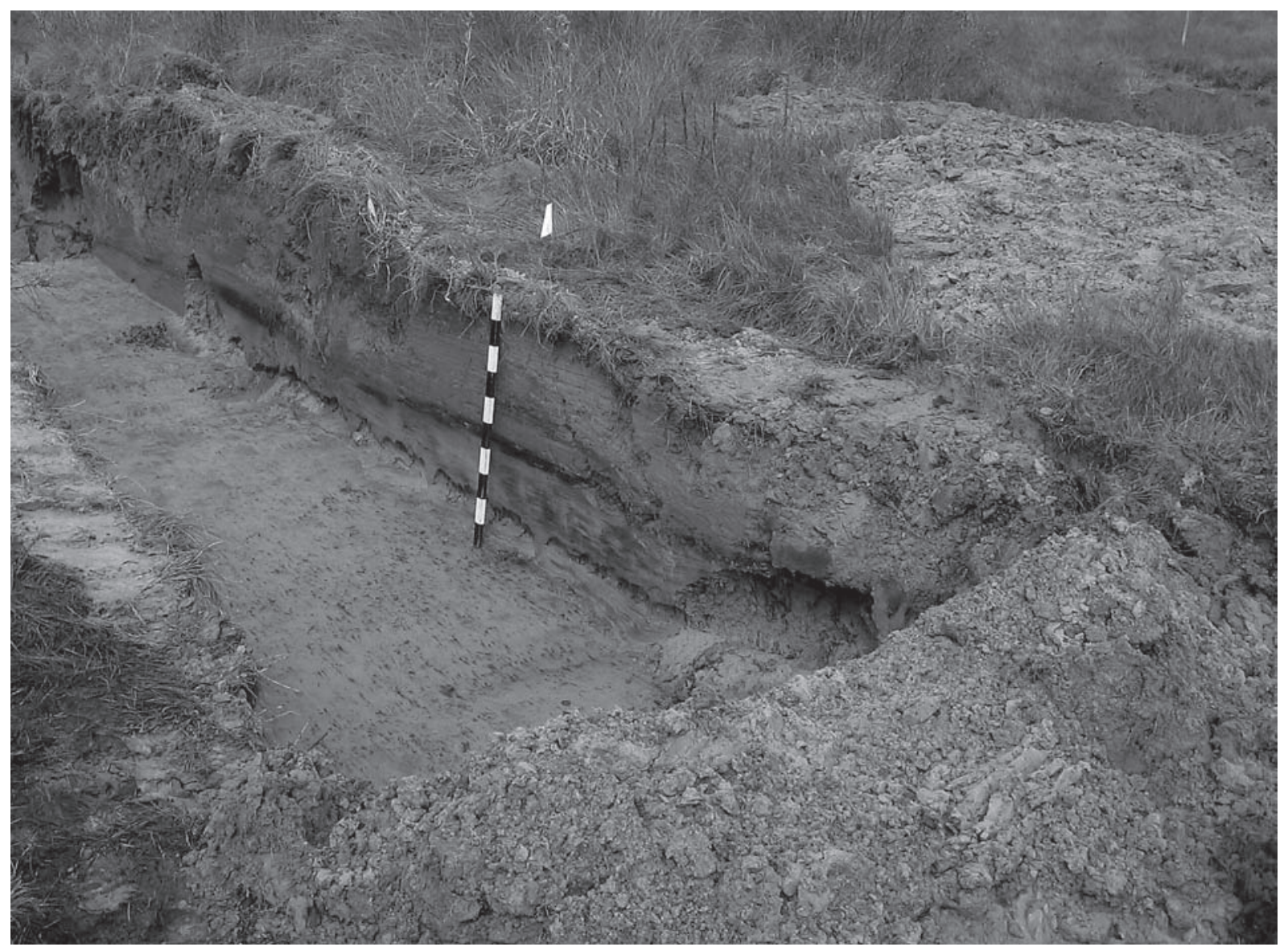

Figure 4.1. Feature 1A, a burned zone exposed in the east wall of Trackhoe Trench 1 (view is northeast).

\section{Feature 3B}

Feature 3B was exposed near the center of Trench 3 and spanned only $2.8 \mathrm{~m}$ long. The charred staining reached from 90 to $100 \mathrm{~cm}$ below the surface. Only a few ceramic vessel sherds were collected from Feature 3B, and only small corroded iron objects were found (but not collected) during the metal detector sweep.

\section{Features 3A, 4A, and 25A}

A large burned area was exposed in three trenches: Trenches 3, 4, and 25 (see Figure 3.6). These were assigned separate feature designations due to locations but are all part of a large burned area. Feature 3A is a moderately intense burn zone compared with Feature 1A. Artifacts, wood fragments and charcoal were exposed, although neither brick fragments nor oyster shell were present. Artifacts collected from Feature
3A include brick fragments, glass (tile and container), bone, ceramic (vessel and pipe), slate fragment, and iron objects. The metal detector identified several iron artifacts including one large unidentifiable chunk, but none of these were collected.

Feature 4 was exposed at the south end of Trench 4 , stretching only ca. $2 \mathrm{~m}$ northward into the trench. The burned area was observed in the profile from 60 to $80 \mathrm{~cm}$ below surface. Brick fragments were present in the feature. Other artifacts collected include a ceramic sherd and container glass.

Feature 25A is an extensive burned zone in the western end of Trench 25 . The feature spanned $14 \mathrm{~m}$ long and was ca. 50-70 cm below the surface, but reached no more than $10 \mathrm{~cm}$ thick across the trench. Feature $25 \mathrm{~A}$ is clearly a continuation of Feature 3A, which was exposed ca. $50 \mathrm{~cm}$ to the north. Fill from this burned zone was removed and piled on the surface for better 
inspection. The base of a wooden post was found; the post measured $44 \mathrm{~cm}$ long and was $12 \mathrm{~cm}$ in diameter. Numerous artifacts including ceramic sherds, a ceramic pipe fragment, container glass, animal bone, coal chunks, burned rocks, and iron objects were collected from the feature.

\section{Feature 6A}

Feature $6 \mathrm{~A}$ appeared in the western end of Backhoe Trench 6. The feature spanned $3.0 \mathrm{~m}$ long and extends from 140 to $150 \mathrm{~cm}$ below surface. Artifacts collected from the feature include a brick fragment, ceramic sherds, and animal bone.

\section{Feature 16A}

Feature 16A, a small burned area, was exposed in the western end of Trench 6 . The feature spans only $2.0 \mathrm{~m}$ long and extends from 130 to $140 \mathrm{~cm}$ below surface. Ceramic sherds were collected from the burned area.

\section{Bone Cluster}

One bone cluster was exposed during trenching. Feature $21 \mathrm{~B}$ is a cluster of bones encountered in the intact sand layer at approximately $50 \mathrm{~cm}$ below surface in the north-central portion of Trench 21 and ca 1.5 m north of Feature 21A, a wooden post. This feature consisted of a tight cluster of bones ca. $20 \mathrm{~cm}$ in diameter exposed by the trackhoe. No evidence of any intrusive pit was found, and no artifacts other than bone were encountered within the feature. No cut marks were evident on the bone.

\section{Bone Pit Features}

Three bone pit features were encountered within an 8-m-long section of Trench 4 . These are designated, from south to north, as Features $4 \mathrm{~B}, 4 \mathrm{C}$, and $4 \mathrm{D}$. All of these features were found as the trackhoe exposed the top of the sand layer, and they are not associated with any burned zone. All three features were on the same approximate level, but their depths below surface varied from 90 to $150 \mathrm{~cm}$, following the rising slope created by the variable thickness of artificial fill. All three were $20-30 \mathrm{~cm}$ deep. Each of the three features appeared to be a roughly circular concentration of remains, primarily animal bones, within a $50-$ to 75-cm-diameter area. With minimal troweling, it became apparent that all three features contained large quantities of jumbled animal bones and a few other cultural items such as bottleglass fragments. Because the features were at the water level, they were completely saturated, and careful excavation and precise documentation were not possible. Portions of each feature were dug by hand, removing and screening the saturated sands so that a sample of the remains could be collected. Doing this also made it possible to determine that these concentrations extended only about 20 to $35 \mathrm{~cm}$ deep into the natural sand layer. It is estimated that the sample of each bone pit feature was approximately 50 percent. All of the recovered animal remains are medium to large mammal, and most appear to be cow bones. Collectively, the three features appear to be trash pits in which butchered animal bones and other debris were discarded. The fact that one pit occurs in close proximity to a wooden post may indicate that these trash pits were dug along an old fence line.

\section{Feature $4 B$}

Feature 4B was encountered in the southern-central portion of Trackhoe Trench 4 . The feature was $50 \mathrm{~cm}$ in diameter, and no pit could be discerned. Artifacts included brick fragments and oyster shell in addition to the bone.

\section{Feature 4C}

Feature $4 \mathrm{C}$ was exposed in the center of Trench 4 between Features $4 \mathrm{~B}$ and $4 \mathrm{D}$, both bone pits. No pit could be discerned in the feature, which is similar to Feature $4 \mathrm{~B}$ and is also $50 \mathrm{~cm}$ in diameter. Artifacts were limited to bone and glass. One piece of glass is particularly interesting and diagnostic. The base of a dark green bottle with the embossed marking of the Ellenville Glass Works is probably from a whiskey bottle manufactured between about 1865 and 1879 (see description below). A vertical wooden post (also described below) was found immediately northwest of the bone cluster, and several handmade red bricks were found around it and adjacent to the main bone cluster. A smaller wooden stake was also found ca. $1 \mathrm{~m}$ north of the features. It is a well-preserved section of machine-cut wood, 1.25-inch square, that certainly represents a modern feature. It had 
been driven into the ground, but its top had been broken off.

\section{Feature 4D}

Feature $4 \mathrm{D}$ was in the north-central portion of Trench 4 . The bone cluster was $60 \mathrm{~cm}$ in diameter and was surrounded by a rough circular pit stain of slightly greenish soil. Artifacts were limited to bone and oyster shell. Feature 4D had a very slightly discolored soil in and around the bones, providing evidence that it was indeed an intrusive pit and had a roughly circular shape.

\section{Wooden Posts}

Five wooden posts were encountered in the excavations, four of which were assigned a feature number; one wooden post bottom was found in Trench 25, but it was displaced by the backhoe. It was found in the western portion of the trench, but its precise location could not be determined, and no feature number was assigned. All of the posts had broken tops indicating that they had been snapped and splintered. The posts may have been broken long ago, perhaps during one of the many hurricanes, or they could have been broken when this property was cleared in the 1990s. One wooden post was found in association with a bone pit (see Feature $4 \mathrm{C}$ above). Three wooden posts were found in situ in the southeastern corner of the project area, and they are designated as Features 18A, 21A, and 23A. Features 21A and 23A consisted of the base of a wooden and a slight stain of darker sand indicating where the post hole had been dug.

Determining the age of the wooden posts is problematic. The presence of wooden posts at the edge of bone pit Feature 4C suggests that the post could be the same age as the pit, which is probably mid-nineteenth century. The age of the other posts is less certain.

\section{Feature 4C}

A wooden post was found at the west edge of Feature 4C, a bone pit, found in the center of Trackhoe Trench 4 . The post was vertical and extended into the historic sandy layer about $24 \mathrm{~cm}$. The top of the post is broken and irregular and appeared to be an old break. The post was $55 \mathrm{~cm}$ long and $16 \mathrm{~cm}$ in diameter. It may have been a cedar post based on its distinctive smell.

\section{Feature 18A}

Feature 18A was exposed at the far southern end of Trench 18 (Figure 4.2a). The feature consisted of the base of a wooden post with several brick fragments and a large corroded and unidentifiable metal object that had been wedged into the posthole to serve as shims (Figure $4.2 \mathrm{~b}$ ). The feature was bisected and the western half removed. The post was small, ca $10 \mathrm{~cm}$ in diameter, and was buried about $38 \mathrm{~cm}$ below the historic sandy layer. A faint posthole could be seen in the lower exposures of the excavation; the posthole stain was highly irregular, indicating some extensive disturbance. The post was removed after excavation; no additional artifacts were found in the base of the excavation. The post measured $55 \mathrm{~cm}$ long.

\section{Features 21A and 23A}

Features $21 \mathrm{~A}$ and $23 \mathrm{~A}$ are post holes exposed in the central portion of Trenches 21 and 23. The area surrounding the posts was cleaned to determine if the posts were associated with other features, but none were found. Small ( $>5 \mathrm{~cm}$ in diameter) remnants of wooden posts were found, but these were very faint. A rounded and more regular posthole stain surrounded each post. No artifacts were found in or around these posthole stains.

\section{ARTIFACTS}

Historic artifacts and modern debris were common on the surface throughout the project area. Modern trash as well as historic glass, ceramic sherds, and bricks were strewn areas across the 5.5-acre lot, but were significantly more prevalent in the southern one-third of the project area and especially common along a twotrack road that enters the property from the east. Once excavation began, it became clear that most of the upper deposits-those incorporated in the dredged fill material-were mixed with modern materials and were not in situ. However, the trench profiles quickly revealed the sand layer beneath the artificial clay fill represented the historic Velasco occupation surface.

Although the scope of work called for general non-collection survey, it also allowed for collection of some diagnostic artifacts at the discretion of the principal investigator. The intent 


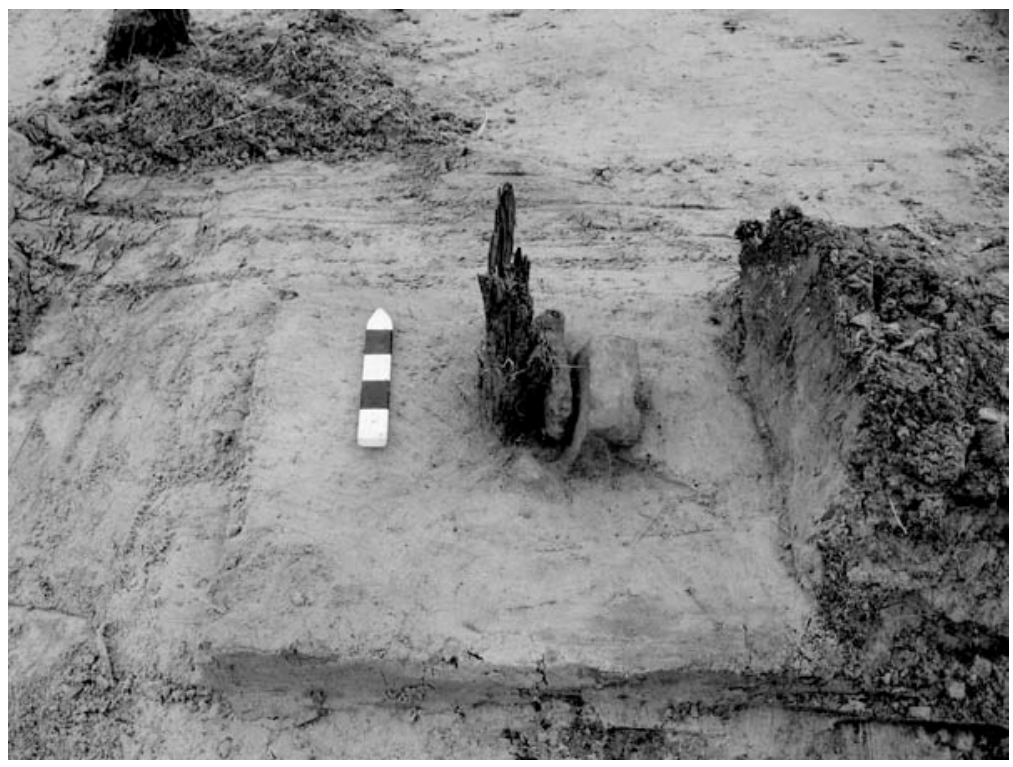

a

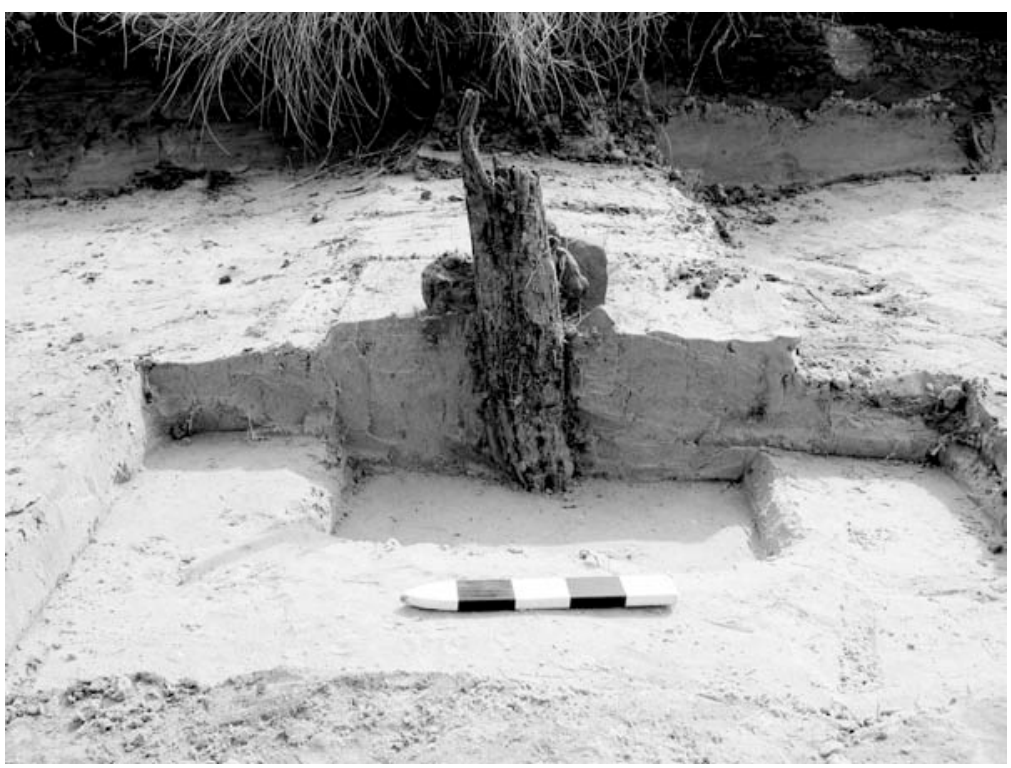

b

Figure 4.2. Photographs of wooden post Feature 18A. (a) view of post when first exposed, looking north. Note the brick and corroded metal object used as shims; (b) profile view of post, looking east.

was that if intact deposits containing artifacts were encountered, they would be recovered during a subsequent testing phase. The subsurface work soon revealed that the Old Velasco surface was extensively disturbed, but pre-1875 materials dominated the artifact assemblage. It was decided that it would be appropriate to obtain a sample of these materials because it represented an area of Old Velasco that had never been sampled before (Block 14 of the original townsite). It was considered likely that this effort would be the only sample of materials from this portion of the old townsite.

The 811 artifacts collected during current investigations at $41 \mathrm{BO} 125$ are assigned to functional categories following the classification 
scheme by South (1977). Of the collected artifacts (see Table 4.1), bones were the most common $(\mathrm{n}=516)$, followed by ceramic vessel sherds $(n=130)$ and container glass $(n=70)$. Other artifact types were less common and include unidentified iron objects $(\mathrm{n}=33)$, brick fragments $(n=19)$, oyster shells $(n=15)$, window glass $(n=7)$, wood fragments $(n=2)$, coal chunks $(\mathrm{n}=4)$, ceramic pipe stem fragments $(\mathrm{n}=3)$, burned rocks $(\mathrm{n}=3)$, brass objects $(\mathrm{n}=3)$, and slate fragments $(n=2)$. Finally, a single specimen was found for each of the following types of artifacts - a glass tile, a brass button, a bone button, and a wooden object (tool?). Artifacts are described below within the following functional categories: structural; kitchen; tobacco; clothing; and unidentified.

\section{Structural}

A total of 27 artifacts collected were originally part of structures. These include bricks, window glass, and a glass tile. Although bricks were common on the surface, within the introduced dredged fill, and in the sandy historic lens, not all bricks found were collected. All of the 19 bricks collected were recovered from features. These were handmade bricks that range in color from pinkish red to strong brown to reddish brown. Feature 3A (the eastern side of a larger burned area) produced two small brick fragments, and Feature 4A (the western side) produced one. Brick was in all three bone pit features: Feature 4B produced 3 fragments, Feature $4 \mathrm{C}$ produced 11 fragments, and Feature 4D produced 2 fragments. One large fragment from Feature 4C measures $4 \frac{1 / 4}{4}$ inches wide and 2 inches thick.

All of the handmade bricks appear to be of the same type described from previous archeological investigations at Old Velasco. Earls et al. (1996:317) notes that the soft red bricks that were used for structures in Velasco are essentially the same as those used for structures in nearby plantations along the Brazos River. The bricks were probably made locally, perhaps at a nearby plantation. It is unlikely that they would have been made at Velasco, because even though suitable clays could be obtained by digging below the sands, there would have been little fuel to fire a kiln-load of bricks.

Flat glass was collected and categorized as functional because it probably served as window glass, although it could have served other functions. Seven pieces of flat glass were recovered: three pieces were from Feature 3B (burned zone), and four pieces were from the general collection in Trench 25 . All are less than $2.5 \mathrm{~cm}$ in length. From Feature 3B, two pieces have a slight greenish tint and are $1.5 \mathrm{~mm}$ and $1.0 \mathrm{~mm}$ thick. The clear piece is $1.3 \mathrm{~mm}$ thick. From the flat glass collected in Trench 25, three pieces have a faint greenish tint. Of these three, two range from 2.35 to $2.2 \mathrm{~mm}$ thick and one is $1.5 \mathrm{~mm}$ thick. The fourth piece is clear and $1.4 \mathrm{~mm}$ thick. Earls et al. (1996:317) notes that window glass was common in coastal port towns by the 1850 s. It is certainly likely that the affluent families that lived in Velasco before the Civil War would have had glass windows.

Finally, one piece of patinated clear glass tile was collected from Feature 3A, a burned zone. The piece is broken and has a maximum length of $3.5 \mathrm{~cm}$. The upper surface of the tile is $5.18 \mathrm{~mm}$ thick. An elevated square grid pattern on the base is ca. $8.5 \mathrm{~mm}$ thick. This specimen is most likely a pressed glass tile.

\section{Kitchen}

Artifacts from five categories can be grouped into a functional kitchen category and total 735 artifacts. These include ceramic vessel sherd, container glass, animal bone, oyster shell, and coal chunks. The most common of these artifacts is bone $(\mathrm{n}=516)$, which was collected from both feature and general trench locations.

\section{Ceramic Vessel Sherds}

The ceramics from the Surfside Beach boat ramp project area include 130 specimens that are classified as vessel sherds and assigned to the kitchen functional group. These ceramics were analyzed and identified by BAS members using the Old Velasco and Quintana comparative collections. The detailed results of this analysis are presented in Appendix A, along with interpretations of the chronology of the ceramic types that comprise the assemblage.

The assemblage is summarized in Table 4.3, which shows the ware types and decorative styles by feature associations. The assemblage includes a wide range of wares that are typical of the early to middle nineteenth century. Almost all of the ceramics probably date from ca. 
1830 to the 1870 s and are likely associated with Old Velasco before the 1875 hurricane. The only notable exceptions are the four sherds of Engobe slipped ware that look like early- to mid-twentieth-century Fiesta ware (see Appendix A). The assemblage is dominated by transfer-printed whitewares, and 13 distinct patterns are identified. The named patterns in the assemblage all date from ca. 1810 to 1882 , and seven of the 13 patterns were probably manufactured before 1850 (see Table A.3 in Appendix A). A sample of the identified transfer-printed whiteware sherds is presented in Figure 4.3.

The collection is comprised only of sherds, and no significant portions of vessels are present. The small sherd sizes reflect, more than anything else, the extensive postdepositional disturbances to the Old Velasco surface. The presence of large burned areas, lack of intact features, and small sizes of ceramics and other artifacts all seem to indicate that the historic Velasco surface is severely disturbed throughout the boat ramp project area. From a functional standpoint, however, many vessel forms were identifiable despite the relatively small sherd sizes. The vessel forms represented in the assemblage are extremely variable, as shown in Table 4.4, and the types of vessels are considered typical of any typical domestic household of the early to middle nineteenth century. No attempt was made to identify the minimum number of vessels represented in the assemblage, but it is safe to say that the number would be in the dozens. As might be expected, plates were the most frequently identified vessel form.

\section{Container Glass}

Seventy pieces of container glass were collected (Table 4.5). These are broken down by provenience and color. The glass colors are classified as clear, aqua, green, dark green and black, and brown. Detailed descriptions of more significant specimens follow.

Two pieces of bottle glass were collected from the surface of the site. One piece is the lip and upper neck fragment of a dark green bottle. Vertical striations are found on the inner rim and may have helped to keep a cork in place. The second fragment is a green body piece. The piece is highly patinated. Both inner and outer surfaces show a rough swirling pattern and may be the result of intensive heating.
A few glass artifacts were found in association with several cultural features. Feature 3A produced five pieces of container glass: two clear body fragments, two dark green body fragments, and one dark green wine bottle kick-up. Feature 4A produced three pieces of container glass: one dark green kick-up, one green thin body fragment, and one thin brown fragment. Five pieces of glass were recovered from Feature 4B. Three are pieces of green bottle glass-two of which appear to be from the same vessel-and two are pieces of dark green glass that appear to be from another vessel. One green bottle base fragment was collected from feature 4D.

Feature $4 \mathrm{C}$ produced 21 pieces of glass. Five pieces are small aqua fragments. Eight dark green fragments are from a bottle with a square base. Finally, eight pieces of green bottle glass are from the same vessel and includes a bottle base with a diagnostic marking. The 3-inch-diameter round bottle base has the name "ELLENVILLE GLASS WORKS" embossed around its perimeter. A number of dark green glass bottles with identical marks were found aboard the Bertrand, a steamship that sank in the Missouri River in Nebraska territory in 1865 (Switzer 1974:29, Figure 38). The Bertrand carried 251 tons of cargo, including cases of whiskey contained in bottles made by several different bottle makers. According to Switzer (1974:71), the Ellenville Glass Company was founded in 1836, and they began using the Ellenville Glass Works name at least by 1865 . The company then changed its name to the Ellenville Glass Factory in 1879. Thus, the bottle base from Feature $4 \mathrm{C}$ probably represents a whiskey bottle manufactured between 1864 and 1879 . The specimen has all the characteristics of a bottle that was hand-blown into a snap-case mold. The find suggests that Feature $4 \mathrm{C}$, and probably the two other bone-pit features (4B and 4D) as well, date to the middle of the nineteenth century.

Glass bottle fragments from nonfeature contexts include specimens from several trenches. Trench 18 produced one fragment of a dark green bottle base, and two dark green bottle fragments were collected from the block area (Trenches 19$24)$. Trench 25 produced 23 glass bottle fragments, and these specimens include five pieces of clear glass and nine of aqua glass. One clear glass specimen is a rim and mouth fragment from a delicate bottle. The narrow mouth and 


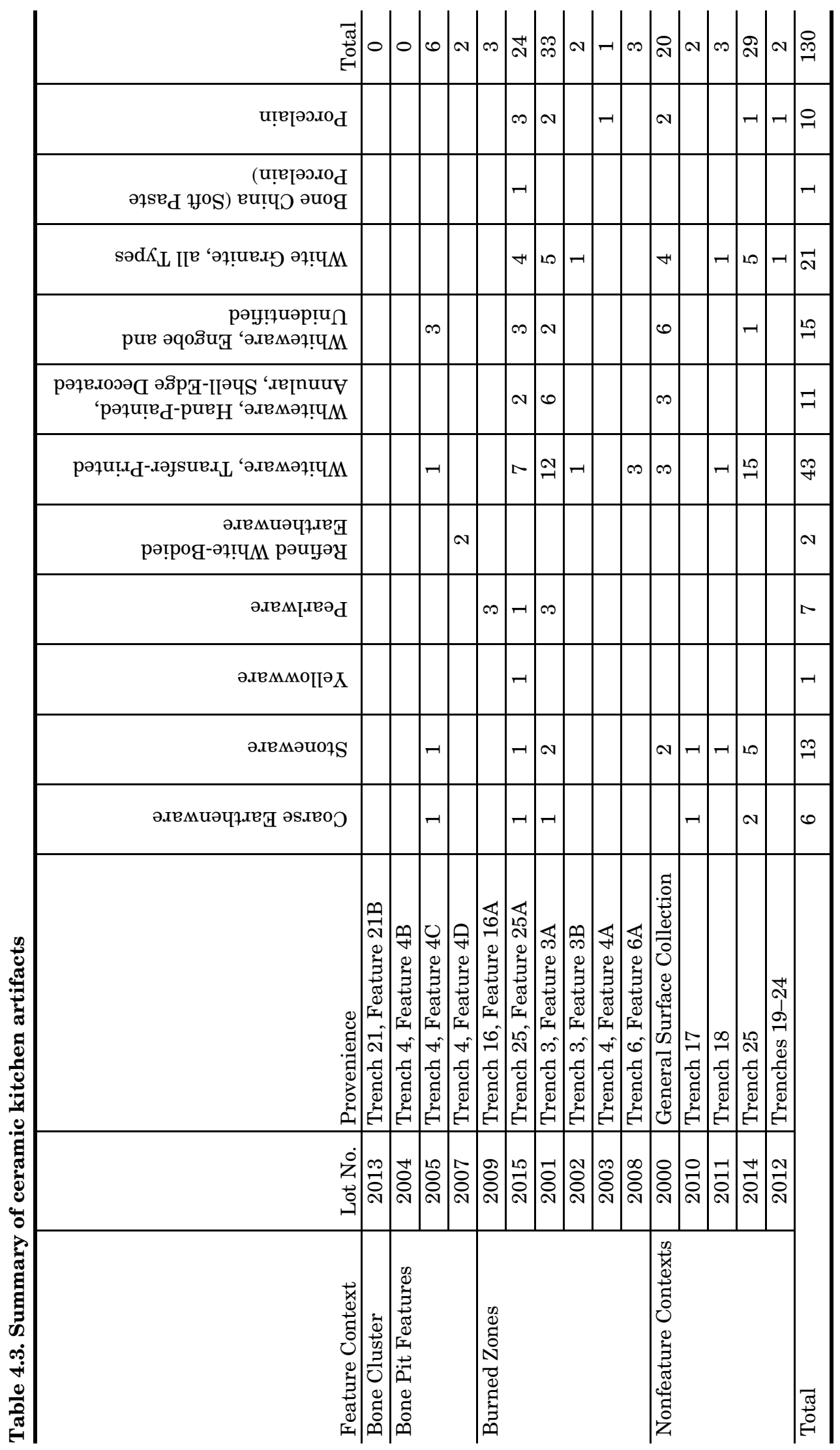



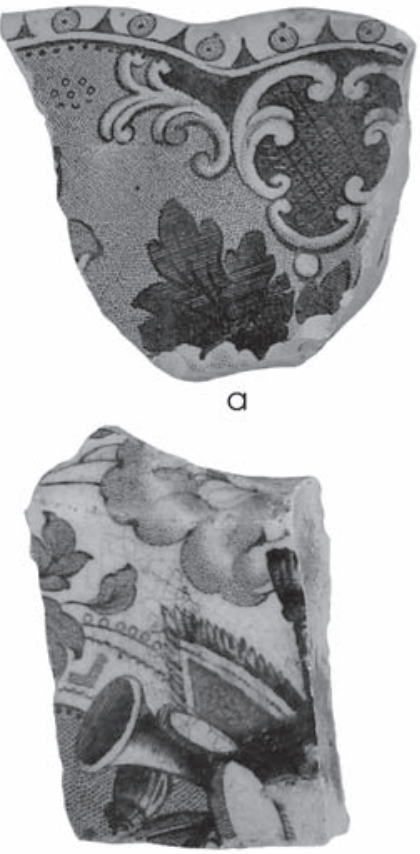

d
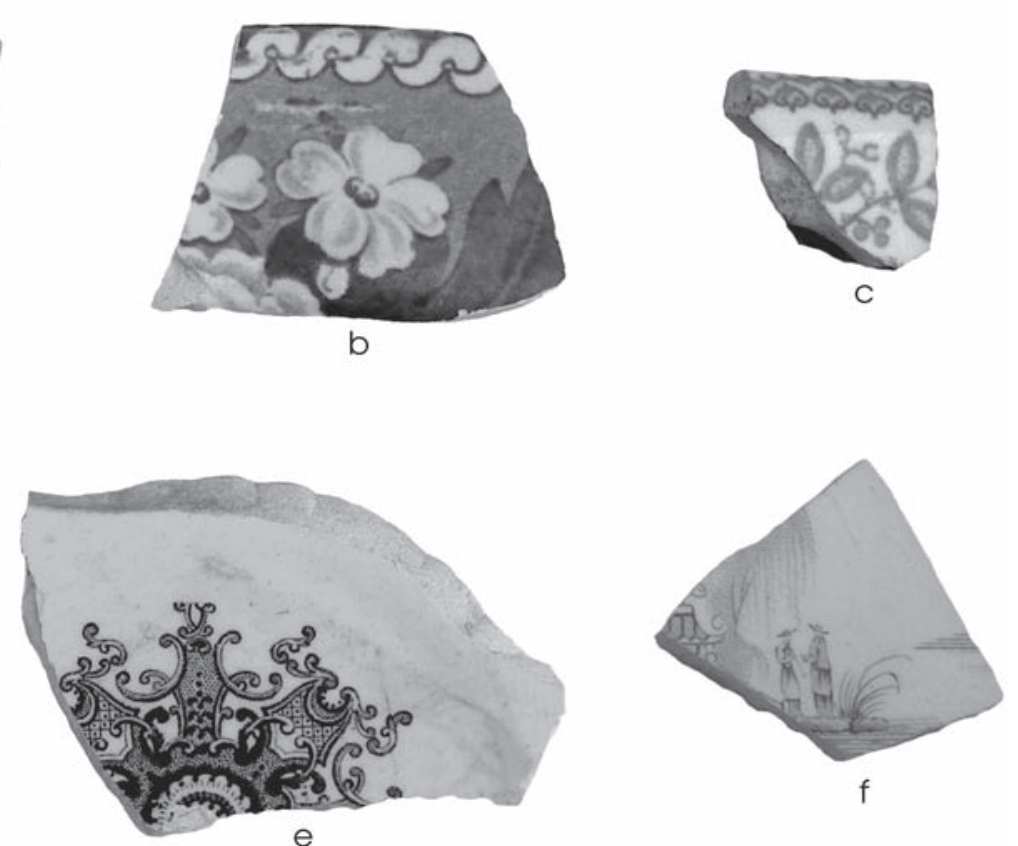

e

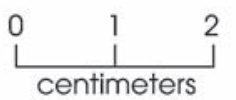

Figure 4.3. Examples of identified transfer-printed ceramics. (a) "Pennsylvania" border pattern in black underglaze on scalloped whiteware rimsherd. (b) "Mare \& Foal" border pattern in blue underglaze on pearlware rimsherd. (c) "Union" pattern in blue underglaze on whiteware cup rim/handle sherd. (d) "Texian Campaigne" pattern in purple underglaze on whiteware bowl body sherd. (e) "Parisian" pattern on whiteware bowl base sherd; (f) "Napier" pattern in green underglaze on whiteware body sherd.

wide lip are indicative of a "wide prescription finish" medicine bottle (see Fike 1987:Figure 2, No. 2.5). The aqua glass is primarily body fragments, but one piece is from a very delicate, thin glass bottle. It has embossed letters “...LD” and "...IA" on the lower body and the square base has a shallow kick-up with a rough pontil mark inside. One of the aqua specimens is a bottle mouth fragment with a simple ring finish (see Fike 1987:Figure 2, No. 2.11). Other bottle glass from Trench 25 includes three pieces of green glass and six pieces of dark green glass. Two of the green pieces appear to be from the same vessel and comprise the base of a relatively thin but large bottle. Of the six dark green specimens, three are heavily patinated and two bottle bases with prominent kick-ups appear to be wine bottles (see Wilson 1981:Figures 72 and 77).

Seven glass bottle fragments were collected from Feature 25A. These include four clear pieces and three green pieces. Of the clear glass, two are fragments from a small decorative vessel with scalloped body walls, possibly a vase of perfume bottle. The base of the bottle has a pontil mark. One piece of clear glass is a bottle base fragment, and the fifth piece is a very thin body fragment, possibly a small perfume or medicine bottle. Of the green glass, two are thick and include a neck fragment and a base fragment, and one is a thinner vessel body fragment.

As was noted with the ceramics, the diversity of glass colors and types of containers seems to reflect a wide range of typical household goods. In addition, the glass assemblage is consistent with expectations for the ca. 1830 to 1875 occupations at Old Velasco.

\section{Animal Bones}

The largest artifact category from the current investigations at $41 \mathrm{BO} 125$ is bone, of which 516 specimens were recovered. These 


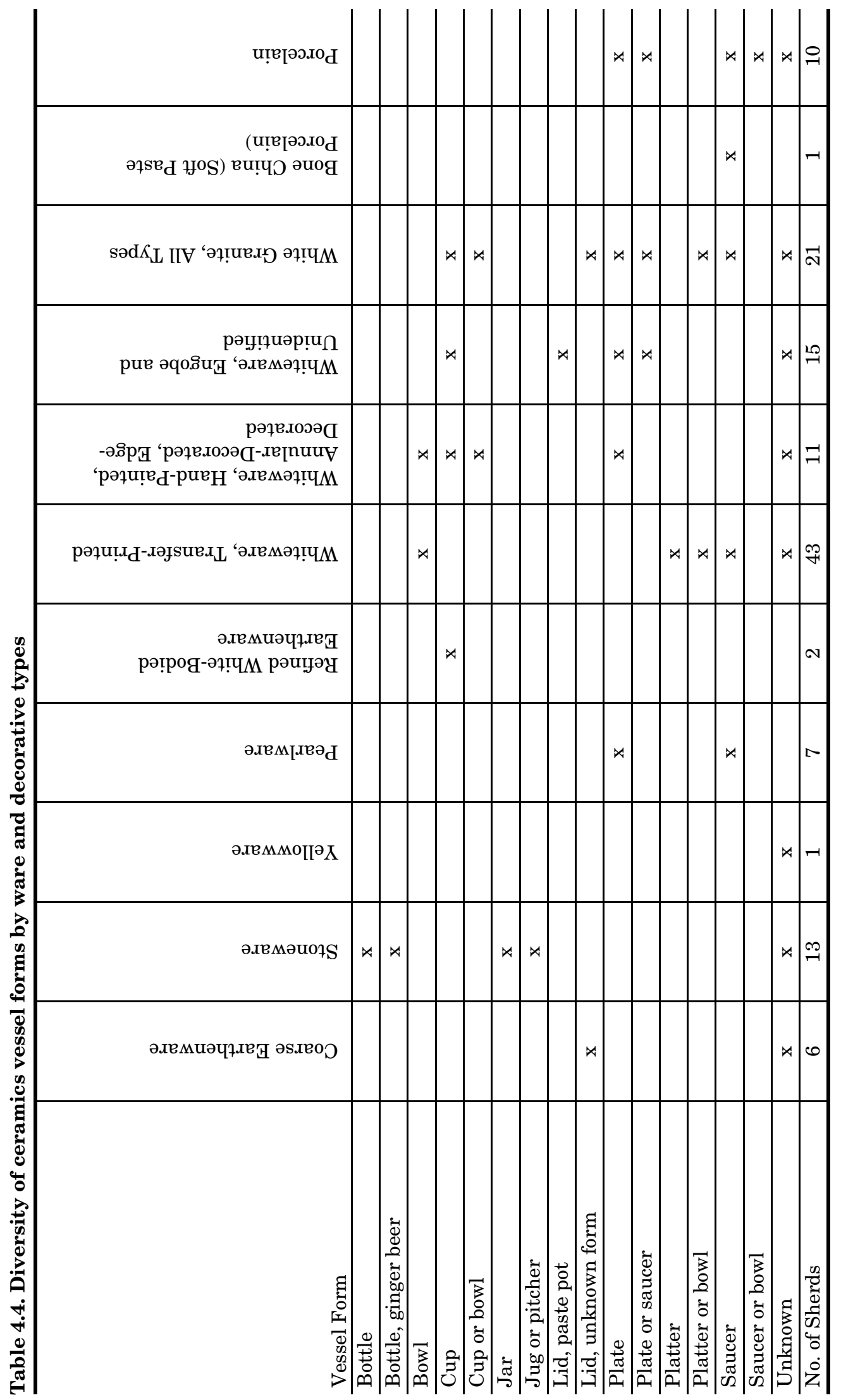


Table 4.5. Container glass by provenience and color

\begin{tabular}{l|c|c|c|c|c|c}
\hline Provenience & Clear & Aqua & Green & $\begin{array}{c}\text { Dark Green } \\
\text { and Black }\end{array}$ & Brown & Total \\
\hline Surface & & & 1 & 1 & 2 \\
\hline Feature 3A & 2 & & & 3 & 5 \\
\hline Feature 4A & & & 1 & 1 & 1 & 3 \\
\hline Feature 4B & & & 3 & 2 & & 5 \\
\hline Feature 4C & & 5 & 8 & 8 & & 21 \\
\hline Feature 4D & & & 1 & & & 1 \\
\hline Trench 18 & & & & 1 & & 1 \\
\hline Treck Area (Trenches 19-24) & & & & 2 & & 2 \\
\hline Feature 25A & 5 & 9 & 3 & 6 & & 23 \\
\hline Total & 4 & & 3 & & & 7 \\
\hline
\end{tabular}

remains were analyzed by Brian Shaffer and are described in Appendix B. A few bones were collected both from general trench contexts, but most (96 percent) were found in association with cultural features (Table 4.6).

The bone assemblage is dominated by medium to very large mammal bones that are not identifiable. The only identifiable bones are fish $(n=1)$, domestic chicken $(n=1)$, deer $(n=1)$, sheep/goat $(\mathrm{n}=3)$, and cow $(\mathrm{n}=118)$. Most of the cow bones were found in the bone pit Features $4 \mathrm{~B}, 4 \mathrm{C}$, and $4 \mathrm{D}$, all clustered together in Trench 4 . These features are interpreted as refuse pits that are dominated by butchered cow bones. A comparison of the minimum number of individual animals and the number of cut bones in these features is interesting (see Tables B.3 and B.4 in Appendix B):

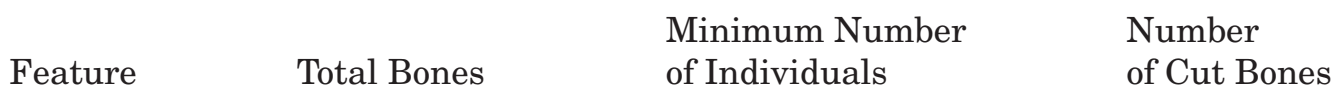

\begin{tabular}{llll}
\hline 4B & 156 & 4 cow & $28(18$ percent $)$ \\
$4 \mathrm{C}$ & 163 & 4 cow, 1 chicken & $10(6$ percent $)$ \\
$4 \mathrm{D}$ & 110 & 3 cow & 26 (24 percent) \\
\hline
\end{tabular}


Archeological Survey of a Portion of Old Velasco

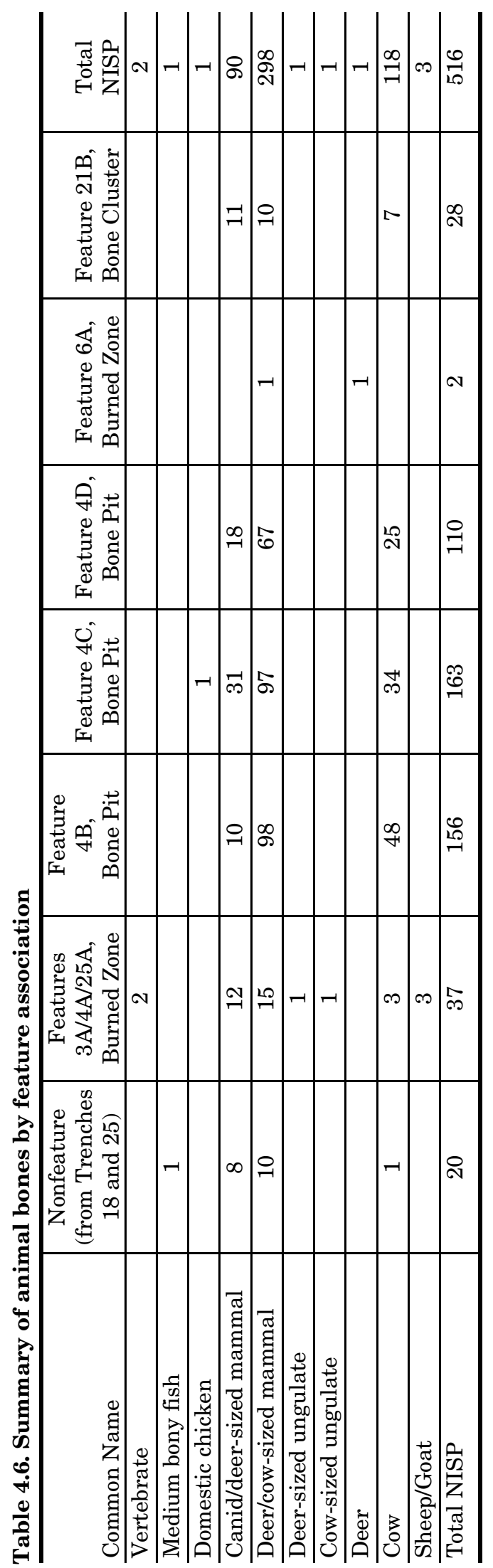




\section{Oyster Shells}

Fifteen oyster shells were collected. They are all associated with the bone pit Features $4 \mathrm{~B}, 4 \mathrm{C}$, and $4 \mathrm{D}$ found in Trench 4 . In these contexts, with oyster shells found in close association with butchered animal bones, it seems likely that shells represent discarded byproducts of harvesting oysters for food.

\section{Coal Chunks}

Two coal chunks were collected in the general artifact collection from Trackhoe Trench 25. The coal was probably used as fuel for domestic fires and cooking.

\section{Tobacco}

Three pipe fragments were collected and are assigned to the Tobacco functional group. One is from surface artifact collections, one is from bone pit Feature $4 \mathrm{C}$, and one is from burned zone Feature 25A. The tobacco pipe terminology used here follows Bradley (2000:Figure 3).

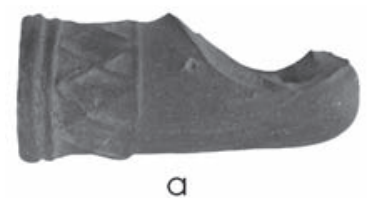

a

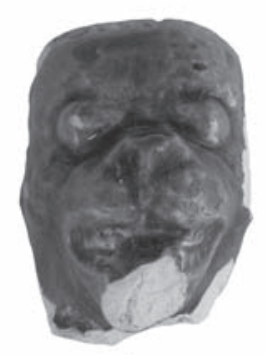

b

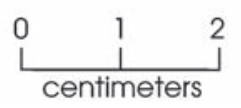

Figure 4.4. Decorative ceramic tobacco pipe fragments. (a) Shank fragment with molded relief decoration, surface collected; (b) Bowl fragment with animal face from Feature 4C.
The specimen from surface collections is a gray stoneware pipe shank fragment decorated with geometric-design relief molding (Figure 4.4a). The fragment is broken at the shank/bowl juncture and the bowl is completely missing. The relief molding is a 0.3 -inch-wide band that encircles the shank at the proximal end (where the stem would be inserted), and the band encloses a pattern of repeated X's.

The second specimen, collected from Feature $4 \mathrm{C}$, is a white-bodied earthernware effigy pipe bowl with a green glaze finish (Figure 4.4b). The front of the bowl is molded and displays the face of an animal, most likely a lion. Bradley (2000:Figures 28 and 29) illustrates a similar style of lion's head on a pipe spark cap that was probably of German manufacture between 1830 and 1860).

The third specimen, collected from Feature $25 \mathrm{~A}$, is a pipestem fragment of white ball clay (Bradley 2000:108). The stem is slightly oval in cross section, with a maximum diameter of $6.22 \mathrm{~mm}(0.245 \mathrm{in})$ and bore hole diameter of $2.0 \mathrm{~mm}(0.0790 \mathrm{in})$.

\section{Clothing}

Only two clothing items were recovered, and both are buttons.

\section{Bone Button}

The first specimen is approximately onehalf of a five-hole, bone button found in association with Feature $4 \mathrm{C}$. It measures 0.83 inches in diameter and 0.10 inches thick. The button has a polished front face recessed central area, but its back face exhibits a crosshatched pattern of saw marks. Having recently conducted detailed studies of bone buttons, Paul Matchen (personal communication 2006) suggests that this specimen was manufactured before the 1850 s because it is a five-hole button that has an unpolished back face. The specimen also has straight-shaft holes, another trait of early button forms dating to the first half of the nineteenth century. It also is notable that the center hole has a different diameter than the other four. Because the four holes are regularly spaced, it is likely that all four holes were drilled simultaneously with a button hole machine (Matchen 2006). 


\section{U.S. Navy Button}

The second clothing specimen is a U.S. Navy button that was surface collected from the top of the artificial dredge spoil in the southern end of the survey area. It probably was dredged out of the Brazos River inlet between the proposed boat ramp and the U.S. Coast Guard station. This button is a flat, one-piece, yellow metal (probably brass) button with a loop shank. Its shank is bent flat and a portion is broken off. The button is tarnished to a dark brown and was covered with a thick layer of blue-green corrosion (probably cuprous chloride, $\mathrm{CuCl}$ ) adhering to the metal. The specimen was cleaned by soaking in clean water, along with gentle hand rubbing to remove the corrosion. The button measures 0.90 inch (just over 7/8 inch) in diameter and 0.07 inches thick. It has an intricate stamped design on its face and impressed letters on its back.

The image on the button face is an eagle perched on an anchor stock, with the anchor oriented vertically and the eagle's head facing left (Figure 4.5). This image is on a background field of fine horizontal lines with 13 stars around it. The edges of the image are rimmed with circular framework consisting of a rope on the

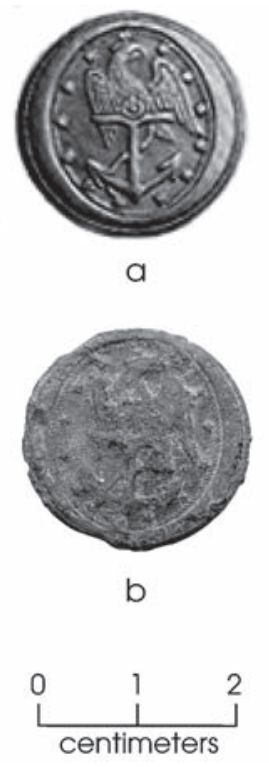

Figure 4.5. U.S. Navy button. (a) Illustration of 1830-1852 U.S. Navy Button adapted from Albert (1969:99, No. NA 86A). (b) Specimen surface collected from dredge spoil pile in southern end of the boat ramp survey area. inside, a smooth banner in the middle, and a rope on the outside.

The back side of the button has an impressed backstamp with the words: LEWIS \& TOMES and EXTRA RICH inside a circular banner around the button. It may have had other letters impressed nearer to the center of the button, but the loop shank obscures this area.

Hughes and Lester (1981:718) identify this particular design as a U.S. Navy button with a pattern that was introduced in 1830 and was in official use until 1852. Earlier buttons are flat, one piece, with the head of the eagle facing left, but the later buttons become convex, and eventually two piece, with the head of the eagle facing right. Hughes and Lester (1981:Plate 307, No. 43) illustrate this button style, as does Albert (1969:99, No. NA 86A). Tice (1997) notes that "from 1830 until the early 1840 s, the Navy purchased buttons depicting an eagle resting on an upright anchor on a lined oval field.”

McQuinn and Bazelon (2001:76, Figure 12) identify the backstamp as the marking used by Lewis \& Tomes, a company of merchants and importers in Birmingham, England, and New York City. The company made buttons in England from 1816 to 1833 . The name Lewis \& Tomes was used for the New York firm from 1819 to 1826 , but it went by other names after this. McQuinn and Bazelon (2001:76) state that "no buttons are believed to have been manufactured for the firm after 1830." They also identify the marking, "Lewis \& Tomes/Extra Rich" as one of the button backstamps used by the firm. These words sometimes appeared alone, but they also appeared along with these designations such as "No. 1" or "No. 4" inside the name banner.

Based on the information provided above, it is likely that the U.S. Navy button found in the boat ramp project area was manufactured around 1830, but it could have been issued to a Navy sailor many years after that. When the button arrived at Old Velasco also is not known, but it was probably in the 1830 s to 1850 s.

\section{Unidentified}

Forty-four collected artifacts either have unknown functions or cannot be categorized. These include slate fragments, iron objects, brass objects, a wooden object, and wood fragments. 


\section{Slate Fragments}

Two slate fragments were collected. The first specimen was from Feature 3A, a burned zone. The piece is 0.1 inches $(3 \mathrm{~mm})$ thick and is dark gray with a slight brown, even purplish hue. The square piece is less than 1 inch in size. The second specimen was collected from Trackhoe Trench 25 , general collection. The second specimen is also 0.1 inches $(3 \mathrm{~mm})$ thick, square and less than 1 inch in size. This piece is a dark charcoal gray.

The brownish purple color of the first specimen may be a result of burning or a characteristic of the particular point of origin. Slate may have been used as a chalkboard, such as might have been used at the customs house to track import and export traffic. Other less likely uses for slate include roofing and flooring, but with such a small sample, these functions are improbable.

\section{Iron Objects}

Thirty-three highly corroded iron objects were collected. These range from a ca. 7.5-inchlong spike-shaped piece and fist-sized globular chunks to smaller pieces.

\section{Brass Objects}

Feature 3A produced three unidentified pieces of yellow metal that is probably brass or bronze. These are all small pieces that cannot be identified because they are highly corroded.

\section{Wood Object}

A well-worked, tapered piece of wood was collected from Trackhoe Trench 25. The needleshaped piece is 6 inches long, but may have been very slightly longer. It is 0.54 inches $(13.9 \mathrm{~mm})$ in diameter at the larger end and tapers to a point. No holes (such as a needle hole) are present. The piece appears to be hand- rather than machine-made, since there are imperfections in the smoothness of the shank. This piece could have been used as a leather or cloth awl, a small stake, or a heavy hairpin.

\section{Wood Fragments}

Two pieces of wood were collected, both from bone pit features. One is a sample of a larger post found in association with Feature $4 \mathrm{C}$. The second is a broken piece of flat, adzed plank from Feature 4D. The first specimen was thought to be cedar, based on its distinctive smell. The second specimen is 3.1 inches wide, $0.6-0.7$ inches thick, and 5.8 inches long. The pale, yellowish brown color of the wood suggests that it might be oak. 



\section{INTERPRETATIONS, SUMMARY, AND RECOMMENDATIONS}

This chapter synthesizes the interpretations of the archeological remains discovered in the excavations in the proposed boat ramp project area. For the most part, the collected artifacts and exposed features (see Tables 4.1 and 4.2) represent remnants of the former townsite of Old Velasco, and it is important to consider these remains within their appropriate historical context but also to understand their postdepositional archeological contexts. Following these interpretations, a brief summary is presented, and management recommendations are offered.

\section{INTERPRETATIONS OF ARTIFACTS AND FEATURES FROM OLD VELASCO}

Old Velasco was settled by 1830 and served as a major port town during the Mexican, Republic of Texas, and early Texas Statehood periods, up until Old Velasco was essentially destroyed by a hurricane in 1875. Using historical evidence, it has been demonstrated that the archeological finds recovered from the southern end of the boat ramp property were on the site of Block 14 of the original Velasco townsite. Several houses, a customs house, and a commercial warehouse were built on this block between 1836 and 1839 (see Table 2.2). The archeological remains do indeed date from about 1830 to 1875 and are most likely associated with several of these locations. Unfortunately, no archeological remains of definable buildings and structures were encountered, and the stratigraphic evidence reveals that the Old Velasco surface has been extensively disturbed in the boat ramp project area.

Fourteen features were identified. Three features are wooden posts (excluding the one associated with a bone pit feature), with well-preserved remnants of the posts found in place in definable postholes with rocks and bricks used as shims. These posts could date to almost any time period, but they are probably twentieth-century features.

Four features are composed primarily of animal bones. One is bone cluster found in Trench 21, but interpretations of this feature are limited. The three bone pit features designated as Features 4B, 4C, and 4C appear to represent relatively intact features that had not been seriously disturbed since Old Velasco times. A total of 429 bones was recovered from these features, and a quick comparison of bone attributes by feature is revealing. Summarizing data presented in Appendix B, Table 5.1 shows that these pit features were dominated by cow bones. Many of the bones were butchered, and some were burned or exhibited spiral fractures. The animal parts represented were mostly spine, ribs, and legs, with shoulder and rump elements also present. From the cutmarks on the bones, faunal analyst Brian Shafer deduced that the bones represent a middle stage of butchering, with little evidence of standardized butchering represented. None of the feet and toe elements or crania and mandibles from initial butchering stages are present, and none of the modified bones represent formal cuts of meat that would indicate butchering for the end consumer (such as short ribs, rib plates, steaks, loin, or roast cuts). Why these animal remains were discarded before being butchered further is not known, but it is possible that they represent portions of the carcasses that were thrown out because they were spoiled. The bone pit features reflect little more than trash dumps that were dug into 
Table 5.1. Comparison of bone attributes represented in bone pit Features 4B, 4C, and 4D

\begin{tabular}{|c|c|c|c|}
\hline Attribute & Feature 4B & Feature $4 \mathrm{C}$ & Feature 4D \\
\hline Total number of bones & 156 & 163 & 110 \\
\hline $\begin{array}{l}\text { Total number of bones by animal group: } \\
\text { Cow and probable cow } \\
\text { Medium to very large mammal } \\
\text { Chicken }\end{array}$ & $\begin{array}{c}48 \\
108 \\
0\end{array}$ & $\begin{array}{c}34 \\
128 \\
1\end{array}$ & $\begin{array}{c}25 \\
85 \\
0\end{array}$ \\
\hline $\begin{array}{l}\text { Minimum Number of Individuals by animal group: } \\
\text { Cow } \\
\text { Chicken }\end{array}$ & $\begin{array}{l}4 \\
0\end{array}$ & $\begin{array}{l}4 \\
1\end{array}$ & $\begin{array}{l}3 \\
0\end{array}$ \\
\hline $\begin{array}{l}\text { Bones with cutmarks: } \\
\text { Number } \\
\text { Percent of total bones }\end{array}$ & $\begin{array}{c}28 \\
17.9 \%\end{array}$ & $\begin{array}{c}10 \\
6.1 \%\end{array}$ & $\begin{array}{c}26 \\
23.6 \%\end{array}$ \\
\hline $\begin{array}{l}\text { Bones with spiral fractures: } \\
\text { Number } \\
\text { Percent of total bones }\end{array}$ & $\begin{array}{c}31 \\
19.9 \%\end{array}$ & $\begin{array}{c}24 \\
14.7 \%\end{array}$ & $\begin{array}{c}3 \\
2.7 \%\end{array}$ \\
\hline $\begin{array}{l}\text { Bones with evidence of burning: } \\
\text { Number } \\
\text { Percent of total bones }\end{array}$ & $\begin{array}{c}1 \\
0.6 \%\end{array}$ & $\begin{array}{c}2 \\
1.2 \%\end{array}$ & $\begin{array}{c}3 \\
2.7 \%\end{array}$ \\
\hline Portions of butchered cows & $\begin{array}{l}\text { Spine, ribs, legs, } \\
\text { and shoulder }\end{array}$ & $\begin{array}{l}\text { Spine, legs, and } \\
\text { rump }\end{array}$ & Spine and legs \\
\hline
\end{tabular}

natural beach sands, probably so that the smelly remains of partially butchered and unbutchered animal carcasses could be buried.

The seven features identified as burned zones are the ones that are most revealing of the old townsite, and they seem to reveal a great deal about what has happened to the site since the 1875 hurricane. Exposures in the mechanical trenches indicate that the burned zones share some several common characteristics: (1) they occur at the base of the artificial fill layers and on top of the Old Velasco sand surface; (2) they contain lots of charred wood, burned and unburned artifacts, and structural debris (bricks, oyster shell, and gravels). The burned zones vary in size, with the largest one observed being about $10 \mathrm{~m}$ long in Trench 1 , but Features $3 \mathrm{~A}$ and $3 \mathrm{~B}$ may be extensions of the same burned zone, as well as Features 25A and 3A.

Another interesting anomaly is interpreted as a drainage ditch that cross-cuts, and hence postdates, the burned zones in several places. The trench profiles reveal a broad cut that extends from northeast to southwest across Trenches 1-4 (see Figure 2). The profiles show that this cut removed a significant portion of the natural sand layer in each of these trenches, and in Trench 3 it bisected what was probably one large burned zone (i.e., Features $3 \mathrm{~A}$ and 3B).
It is apparent that this cut post dates the formation/deposition of the burned zone, and it is likely that this represent a modern drainage ditch, probably from the twentieth century.

There are two different interpretations of the presence of these burned zones. One is that they are locations where Old Velasco structures and features were burned many years ago, perhaps as a means of eliminating buildings ruined in one of the many hurricanes of the late 1800 s. An alternative possibility is that the burned zones represent a relatively modern phenomenon. Aerial photographs of this location from the 1950s through 1990 show that most of this area was overgrown with dense vegetation, presumably salt cedar. It is possible that mechanical vegetation clearing was done in the mid-1990s in conjunction with the Freeport Harbor improvements that included jetty work, creation of the inlet, and moving of the U.S. Coast Guard station. In order to prepare the property for disposal of dredge material from the inlet, one of the first tasks might have been to blade the area, burn piles of brush and other debris that was dumped there, and then blade the area smooth again. Both of these explanations are plausible, and either could result in horizontally extensive burned zones seen in the archeological trench excavations. 
Regardless of when these events occurred, the burned zones leave little doubt that the Old Velasco surface is extensively disturbed in the southern portion of the project area. Despite rather intensive trenching, no brick foundations, cisterns, or other intact structural features were found. The widespread evidence of disturbance and burning suggests a systematic destruction of the surface in the boat ramp area before the Freeport Harbor improvements of the mid-1990s. Notably, historic architectural features made of brick and mortar-a house foundation and large shallow cistern-are intact and well preserved about $120 \mathrm{~m}$ to the southeast. The Cradle of Texas Conservancy and the Brazosport Archeological Society have been investigating these Old Velasco ruins for several years, but this area was never disturbed like the boat ramp property was.

The primary goal of the excavations in the boat ramp project area was to define the nature of the deposits and to locate any intact cultural features that might exist. A secondary goal was to collect a sample of the cultural materials from this portion of the townsite. The collected sample of 811 specimens is classified functionally as follows:

$\begin{array}{lr}\begin{array}{l}\text { Structural (bricks, window } \\ \text { glass, glass tile) }\end{array} & 27 \\ \text { Kitchen (ceramics and glass) } & 200 \\ \text { Kitchen (bones and oyster } & \\ \quad \text { shells) } & 531 \\ \text { Tobacco (pipe fragments) } & 3 \\ \text { Clothing (buttons) } & 2 \\ \text { Unclassified (other) } & 44\end{array}$

The artifact assemblage is not a systematic sample, and the overall numbers of specimens are misleading because the collection strategy emphasized recovery of all temporally diagnostic specimens (such as decorated ceramics and bottle glass). Only a small sample of the less diagnostic and bulky artifacts, especially brick fragments and oyster shells, was recovered. From a functional standpoint, the overall assemblage represents the kind and diversity of materials that would typically be found in any moderate- to high-income household in a port town like Old Velasco. Most of the temporally diagnostic artifacts were manufactured from the 1830 s through the $1870 \mathrm{~s}$. A fair number of specimens (a U.S. Navy button, some of the bottle glass, and at least 23 of the 130 ceramic sherds) were made before 1850 . As was true with previous archeological investigations at Old Velasco, the transfer-printed whiteware ceramics turned out to be the most temporally diagnostic group of artifacts, and 13 distinctive transfer print patterns were identified in this assemblage (see Appendix A).

\section{SUMMARY AND RECOMMENDATIONS}

PAI archeologists directed the excavation and monitored the digging of 25 mechanical trenches in the area that the Village of Surfside Beach proposed for a boat ramp and parking facility. No cultural remains were found in the northern three-quarters of the Surfside boat ramp property, and no further archeological work is warranted in this area. The excavations revealed that historic remains associated with the Old Velasco townsite and dating from the 1830 s to the 1870 s are present in the southern end of the project area. Despite the intensity of trenching in this southern area where the Old Velasco remains were found, no "key structural features" like those encountered by Earls et al. (1996:77) in previous archeological work were found. In fact, the number and distribution of burned zones found at the top of the natural sand layer indicate that the Old Velasco surface is no longer intact in the southern end of the project area. Lacking any evidence of intact key structural features, the archeological remains in the southern area cannot be linked to specific buildings or structures, so their interpretive value is somewhat limited. It is recommended that the analysis and interpretation of the sample of artifacts recovered during this survey effectively constitute the mitigation of damages that will be caused by the construction of the boat ramp and parking facility. Furthermore, it is recommended that because the cultural deposits have limited research potential, the portion of the Old Velasco townsite within the southern end of the project area is not eligible for listing in the National Register of Historic Places under Criterion D (potential to yield information). This portion of the project area also does not meet the criteria for designation as a 
State Archeological Landmark under the Texas Antiquities Code.

If a substantially intact and significant cultural feature is found during construction of the boat ramp, the Village of Surfside Beach should notify the U.S. Army Corps of Engineers and the Texas Historical Commission. Surfside Beach has agreed to allow members of the Brazosport Archeological Society to monitor the construction excavation and removal of the Old Velasco surface in the southern end of the project area. 


\section{REFERENCES CITED}

Albert, Alphaeus H.

1969 Record of American Uniform and Historical Buttons, Bicentennial Edition. Revised edition. Boyertown Publishing Co., Boyertown, Pennsylvania.

Bache, A. D

1858 "Preliminary Chart of Entrance to Brazos River, Texas." [From a Trigonometrical Survey Under the Direction of A. D. Bache, Superintendent of the Survey of the Coast of the United States. Triangulation by J. S. Williams, Asst., Topography by J. M. Wampler, Sub-Assistant, Hydrography by the Parties Under the Command of Lieuts. Comdg. F. J. De Haven and J. K. Duer, U.S.N. Assts. Triangulation and Topography Executed in 1952.] on file, Center for Archaeological Research, The University of Texas at San Antonio.

Blake, Marie E., and Martha Doty Freeman

1998 Nineteenth-Century Transfer-Printed Ceramics from the Texas Coast: The Quintana Collection. U.S. Army Corps of Engineers, Galveston District.

Bradley, Charles S.

2000 Smoking Pipes for the Archeologist. In Studies in Material Culture Research, edited by Karlis Karklins, pp. 104-133. The Society for Historical Archaeology. Parks Canada, Ottowa.

Bryan, J. P., editor

1965 Mary Austin Holley. The University of Texas Press, Austin.

Bureau of Land Management

2006 Historic Glass Bottle Identification \& Information Website. Online publication by the Bureau of Land Management, U.S. Department of the Interior. Available from http://www.blm.gov/historic_bottles [accessed September 20, 2006].

Earls, Amy C., Terri L. Myers, Brian S. Shaffer, Karl W. Kibler, Karen M. Gardner, Laurie S. Zimmerman, Elton R. Prewitt, and Sandra L. Hannum

1996 Testing and Data Recovery at the Townsite of Old Velasco (41BO125), Brazoria County,
Texas. Reports of Investigations No. 94. Prewitt and Associates, Inc., Austin.

Fike, Richard E.

1987 The Bottle Book: A Comprehensive Guide to Historic, Embossed Medicine Bottles. Peregrine Smith Books, Salt Lake City, Utah.

Fox, Anne A., James E. Ivey, and J. Carroll Markey 1981 Cultural Resource Survey, Freeport Harbor, Texas (45-Foot) Navigation Improvement Project, Brazoria County, Texas. Archaeological Survey Report No. 107. Center for Archaeological Research, The University of Texas at San Antonio.

Freeman, Martha Doty

1998 A History of Quintana, A Nineteenth-Century Coastal Port in Brazoria County, Texas. Reports of Investigations No. 117. Prewitt and Associates, Inc., Austin.

Hughes, Elizabeth, and Marion Lester

1991 The Big Book of Buttons. Reprinted by New Leaf Publishers, Sedgwick, Maine.

Ippolito, John E., and Edward P. Baxter

1976 An Archeological Survey of the Freeport Harbor 45-Foot Navigation Project, Brazoria County, Texas. Report 21. Anthropology Laboratory, Texas A\&M University, College Station.

Kleiner, Diana J.

2001 Surfside Beach, Texas. In The Handbook of Texas Online. Available from http:// www.tsha.utexas.edu/handbook/online/articles/SS/hls90.html [accessed July 31,2006].

Lawrence, Ken, and Kevin A. Miller

2005 Cultural Resource Investigations for the Freeport LNG Project in Brazoria County, Texas. SWCA Cultural Resource Report No. 04-366. SWCA Environmental Consultants, Austin.

Matchen, Paul M.

2006 Utilitarian Bone Button Classification: A Technological Approach. Unpublished paper presented at the 71st Annual Meeting, Society for American Archeology, San Juan, Puerto Rico. 
McQuinn, William F., and Bruce S. Bazelon

2001 American Military Button Makers and Dealers: Their Backmarks \& Dates. Revised edition. BookCrafters, Inc., Fredericksburg, Virginia.

Myers, Terri L.

1996 Historical Background. In Testing and Data Recovery at the Townsite of Old Velasco (41B0125), Brazoria County, Texas, by Amy C. Earls, Terri L. Myers, Brian S. Shaffer, Karl W. Kibler, Karen M. Gardner, Laurie S. Zimmerman, Elton R. Prewitt, and Sandra L. Hannum, pp. 39-75. Reports of Investigations No. 94. Prewitt and Associates, Inc., Austin.

Pollan, Sandra D., W. Sue Gross, Amy C. Earls, Johnney T. Pollan, Jr., and James L. Smith

1996 Nineteenth-Century Transfer-Printed Ceramics from the Townsite of Old Velasco (41B0125), Brazoria County, Texas: An Illustrated Catalogue. U.S. Army Corps of Engineers, Galveston District.

Switzer, Ronald R.

1974 The Bertrand Bottles: A Study of 19th-Century Glass and Ceramic Containers. National Park Service, U.S. Department of the Interior, Washington, D.C.
Texas Land Trust Council

2006 Cradle of Texas Conservancy listing in the Texas Land Trust Directory. Online organization list published by the Texas Land Trust Council. Available from http://www.texasland trusts.org/land_trusts/directory/?id=13 [accessed July 31, 2006].

Texas State Historical Association

2001 The Battle of Velasco. In The Handbook of Texas Online. Available from http://www.tsha. utexas.edu/handbook/online/articles/VV/ qfv1.html [accessed July 31, 2006].

Tice, Warren K.

1997 Uniform Buttons of the United States, 1776 1865. Thomas Publications, Gettysburg, Pennsylvania.

Weir, Merle

2001 Velasco, Texas. In The Handbook of Texas Online. Available from http://www.tsha. utexas.edu/handbook/online/articles/VV/ hvv7.html [accessed July 31,2006].

Wilson, Rex L.

1981 Bottles on the Western Frontier, edited by Edward Staski. University of Arizona Press, Tucson, Arizona, in collaboration with the Southwest Parks and Monuments Association. 


\section{APPENDIX A: Analysis of Ceramic Vessel Sherds}

Sandra D. Pollan, Johnney T. Pollan, Jr., and Douglas K. Boyd 



\section{INTRODUCTION}

Several Brazosport Archeological Society (BAS) members visited the Surfside Beach boat ramp project location during the Prewitt and Associates, Inc. (PAI), archeological investigations in February 2006, and it was clear that many of the ceramic sherds being recovered were nineteenth-century transfer-printed wares like those previously recovered and described from Old Velasco and Quintana (Blake and Freeman 1998; Pollan et al. 1996). Following the field investigations, PAI submitted 130 ceramic sherds from the townsite of Old Velasco to BAS for identification. BAS was asked to examine this collection because their members had considerable experience with these ceramics, and the comparative collections are housed at the Brazosport Museum of Natural Sciences in Clute, Texas. The ceramic assemblage from the boat ramp project area was analyzed by BAS members Sandra and Johnney Pollan in March and April 2006.

This appendix presents definitions of ceramic terms and a table of attributes, observations, identifications, and interpretations for each of the analyzed ceramic sherds. Tables summarizing the Surfside Beach boat ramp ceramic assemblage also are presented.

\section{CERAMIC ATTRIBUTES AND ANALYSIS RESULTS}

A detailed attribute analysis was conducted on the sherds recovered during the Surfside boat ramp project. The attributes used for this analysis include: lot number (keyed to provenience); individual specimen number; sherd size; sherd type; vessel form; ware type; decorative type and finish; and decorative motif or pattern; other description; and chronology. The attributes recorded for each specimen are presented in Table A.1 at the end of this appendix, along with a summary table listing all of the transfer-print patterns that are identified in this assemblage.

The lot numbers are keyed to proveniences as follows:

\begin{tabular}{|c|c|c|c|}
\hline Lot Number & Provenience & Feature Association & Feature Type \\
\hline 2000 & Surface Collection & none & - \\
\hline 2001 & Trench 3 & $3 \mathrm{~A}$ & burned zone \\
\hline 2002 & Trench 3 & $3 \mathrm{~B}$ & burned zone \\
\hline 2003 & Trench 4 & $4 \mathrm{~A}$ & burned zone \\
\hline 2004 & Trench 4 & $4 \mathrm{~B}$ & bone pit feature \\
\hline 2005 & Trench 4 & $4 \mathrm{C}$ & bone pit feature \\
\hline 2007 & Trench 4 & $4 \mathrm{D}$ & bone pit feature \\
\hline 2008 & Trench 6 & $6 \mathrm{~A}$ & burned zone \\
\hline 2009 & Trench 16 & $16 \mathrm{~A}$ & burned zone \\
\hline 2010 & Trench 17 & none & - \\
\hline 2011 & Trench 18 & none & - \\
\hline 2012 & Trenches 19-24 & none & - \\
\hline 2013 & Trench 21 & $21 \mathrm{~B}$ & bone cluster \\
\hline 2014 & Trench 25 & none & - \\
\hline 2015 & Trench 25 & $25 \mathrm{~A}$ & burned zone \\
\hline
\end{tabular}


With few exceptions, the terminology used here for ware types, decorative types and finishes, and decorative motifs (see Glossary below) is consistent with the terms used and defined by Majewski and O'Brien (1984, 1987). This classification uses ware types in conjunction with decoration to sort the ceramics into meaningful groups. Ware types in this assemblage are classified as coarse earthenware, stoneware, refined white-bodied wares, bone china, and porcelain. The common decorative types represented in this assemblage are Albany slip, painted (includes annular and hand-painted decorations), Bristol slip, edgedecorated, salt-glazed, and transfer printed.

Each sherd was also classified by size as being small $(<3 \mathrm{~cm})$, medium $(3-6 \mathrm{~cm})$, or large $(>6 \mathrm{~cm})$. Each specimen was also classified by sherd type and vessel form, and these are interrelated variables. The vessel form terminology, which is used to describe the sherd types, is consistent with that presented in the Old Velasco and Quintana ceramic catalogs (Pollan et al. 1996:Figure 3, 4, 5 and 6; Blake and Freeman 1998:Figures 2 and 3). Common terms for vessel form and sherd types need no explanation, but many of the ceramic terms used in Table A. 1 are defined below.

\section{GLOSSARY OF TERMS}

The terms used in this appendix to classify and describe ceramic ware types, decorative types, and transfer-print patterns are defined below. Ware types are defined based on how vitreous (glasslike) a ceramic paste is, which is a function of the firing temperature and the composition of the paste. Wares may be generally grouped as nonvitreous, semivitreous, or vitreous, with the degree of vitreousity increasing with firing temperature (Majewski and O'Brien 1987:112). Ware types are listed below from least to most vitreous. Decorative types and transfer print patterns are listed alphabetically.

\section{Ware Types}

Coarse earthenware (also called unrefined earthenware) is a term for a wide variety of ceramics fired at very low temperatures and having a very soft paste (about 2.0 to 4.0 on the Mohs scale of hardness). These may include redwares, brownwares, and yellowware (Majewski and O’Brien 1984:21).

Stoneware refers to ceramics that were fired at relatively high temperatures and have partially vitrified bodies of various colors such as brown, gray, or white, often covered by a hard glaze. Stoneware pottery forms are typically utilitarian vessels used in every household, such as jugs and bottles designed to hold liquids (Greer 1981:55-106, 268).

Whiteware refers to all nonvitreous white-bodied earthenwares with a clear glaze. Transfer prints were most often applied to whitewares (Blake and Freeman 1998:122; Majewski and O'Brien 1984:22; 1987:119). The creamwares and pearlwares of the late 1700 s and early 1800s evolved into a more refined whiteware. Creamwares are characterized by a creamy, yellow body with colorless glaze. Pearlwares were essentially a creamware body with blue cobalt glaze added to create whiter finished product. The blue cobalt is usually puddled along crevices, but the overall vessel generally has a faint greenish tint due to layering of transparent blue glaze over a yellow body. A true whiteware has cobalt added to the body rather than the glaze, thus creating a pure white body with a colorless glaze.

White granite is a semivitreous to vitreous white-bodied earthenware and is often called ironstone (Blake and Freeman 1998:122). The classic ironstones from the 1840 s to 1890 s were typically undecorated but characterized by distinctive vessel shapes (Majewski and O’Brien 1984:22-23; 1987:120-124). Dieringer and Dieringer (2001) and Wetherbee (1980, 1985, 1996) describe the classic ironstone and white granite vessel forms and shapes that were common during this period. White granite or ironstone wares sometimes were decorated with transfer prints or flow-printed patterns (Blake and Freeman 1998:122), but they often were plain white, with the only decoration being relief-molded shapes such as fluted, paneled, or ribbed (Majewski and O’Brien 1984:46).

Bone china refers to soft- and medium-paste porcelain (Majewski and O'Brien 1984:24; 1987:126). 
Porcelain, as used here, refers only to hard-paste porcelain that was fired at very high temperatures and has a fully vitrified body with surfaces that have a glass-like appearance (Majewski and O’Brien 1984:23-24; 1987:125-126).

\section{Decorative Types and Terms}

Albany Glaze refers to a brown, dark brown, or black slip glaze that was commonly applied to American stonewares. The classic Albany glaze is a "chocolate-brown" color (Greer 1981:38, 180-193, 264, 265).

Annular-Decorated refers to horizontal bands or lines of colored slip applied to a vessel, most commonly applied to hollow vessel forms such as bowls, mugs, and cups (Majewski and O’Brien 1984:44-45).

Bristol Glaze refers to a creamy white, bluish white, or beige slip glaze that was commonly applied to American stonewares in the early twentieth century (Greer 1981:47, 194-202, 264, 265).

Edge-Decorated refers to relief-molded designs found along the edges of vessels (Majewski and O'Brien 1984:36-38). Shell edge decoration is a common type in which the rim of the vessel has a scalloped edge. Relief-molded edge decorations may be plain or hand-painted in various colors.

Engobe refers to a colored slip applied to the interior and exterior surfaces of a vessel for decorative effect. This type of slip, which was often created using a metal oxide compound, dates to the twentieth century. The brightly colored "Fiesta Wares" popularized in the 1930s are a good example of engobe (Majewski and O’Brien 1987:164).

Flow Blue refers to a blurry or misty blue decoration on white-bodied ceramics, most commonly on blue transfer-printed wares, that was created intentionally to imitate the look of Chinese porcelains (Blake and Freeman 1998:121; Pollan et al. 1996:6; Majewski and O'Brien 1984:22; 1987:143). The blue softening effect was created by adding a volatizing mixture, such as chlorides, into the kiln during firing.
Glaze and Slip are often confused. Both refer to coatings applied to a vessel to give its interior and/or exterior surfaces a particular look and porosity. Majewski and O'Brien (1987:109) state that glazes are applied to "seal the body, to improve vessel appearance, and to protect decoration." The terms are sometimes used synonymously, but, as used here, the term slip refers to an opaque (often colored) coating of clay thinned with water, and the term glaze is used for a translucent or clear coating that fuses like glass to the vessel surface (see Slip Glaze).

Hand-Painted refers to decorations that were hand-painted onto a completed ceramic vessel, both before and after firing. Typically, the decorations are under the clear glaze. For detailed descriptions of various hand-painting techniques and styles, see Majewski and O'Brien (1987:147-164).

Salt Glaze refers to a stoneware glaze created by vaporizing common table salt. "The sodium reacts with the silica and alumina compounds to form a soda glass or glaze...The salt vapor usually does not reach the interior of the vessels in enough concentration to form a true glaze" (Greer 1981:180). The resulting surface texture resembles an "orange peel" (Greer 1981:181).

\section{Slip (see Glaze and Slip)}

Slip Glaze refers to a decorative technique in which all or most of the surface of a vessel is covered with a colored glaze consisting of clay thinned with water (Majewski and O'Brien 1984:45). Common types of slip glazes include Albany, Bristol, and engobe.

Sprig refers to fine-line black stems typically found as parts of small flowers and berries on painted wares (see Majewski and O'Brien 1987:158-159, Figure 5b).

Transfer-Printed refers to a decoration technique in which an intricate image, usually in a single color, was printed onto tissue paper and then was applied or transferred to the surface of a ceramic vessel. The transfer image was placed onto the vessel and fired at low temperature to cause the colored ink to adhere, then the vessel was glazed and fired so that the image is sealed 
underneath the protective translucent glaze. Common monochrome colors of transfer-printed whitewares are blue, deep blue, red, purple, brown, gray, black, and green, while bichrome colors are rather rare (Gross et al. 1996; Majewski and O’Brien 1987:141-142).

\section{The Ceramic Assemblage from the Surfside Beach Boat Ramp Project}

Table A.1 presents all of the attributes for each of the 130 ceramic sherds in the Surfside Beach boat ramp assemblage. Table A.2 summarizes the assemblage by ware type and decorations. As shown in Table A.2, transferprinted ceramics make up the bulk of the assemblage, but the sample is skewed somewhat because small sherds of undecorated whiteware were not always collected but any sizable piece of transfer-printed ware (i.e., anything larger than a quarter with a recognizable image) was collected. Nevertheless, transfer-printed wares were common, and they are the most diagnostic specimens for chronological purposes. Specific transfer-print patterns represented in the Surfside boat ramp assemblage are summarized in Table A.3, along with the probable dates of manufacture for each pattern. Of all of these patterns listed, only one-the Mare and Foal pattern-is not represented in the published catalogues of transferprinted wares from Old Velasco and Quintana. It is notable that most of the patterns in this assemblage predate 1850 , and only the "Texian Campaigne" was manufactured after 1851. All of the transfer-printed specimens in the assemblage were probably manufactured and deposited at Old Velasco before the devastating hurricanes of 1871 and 1875 . 


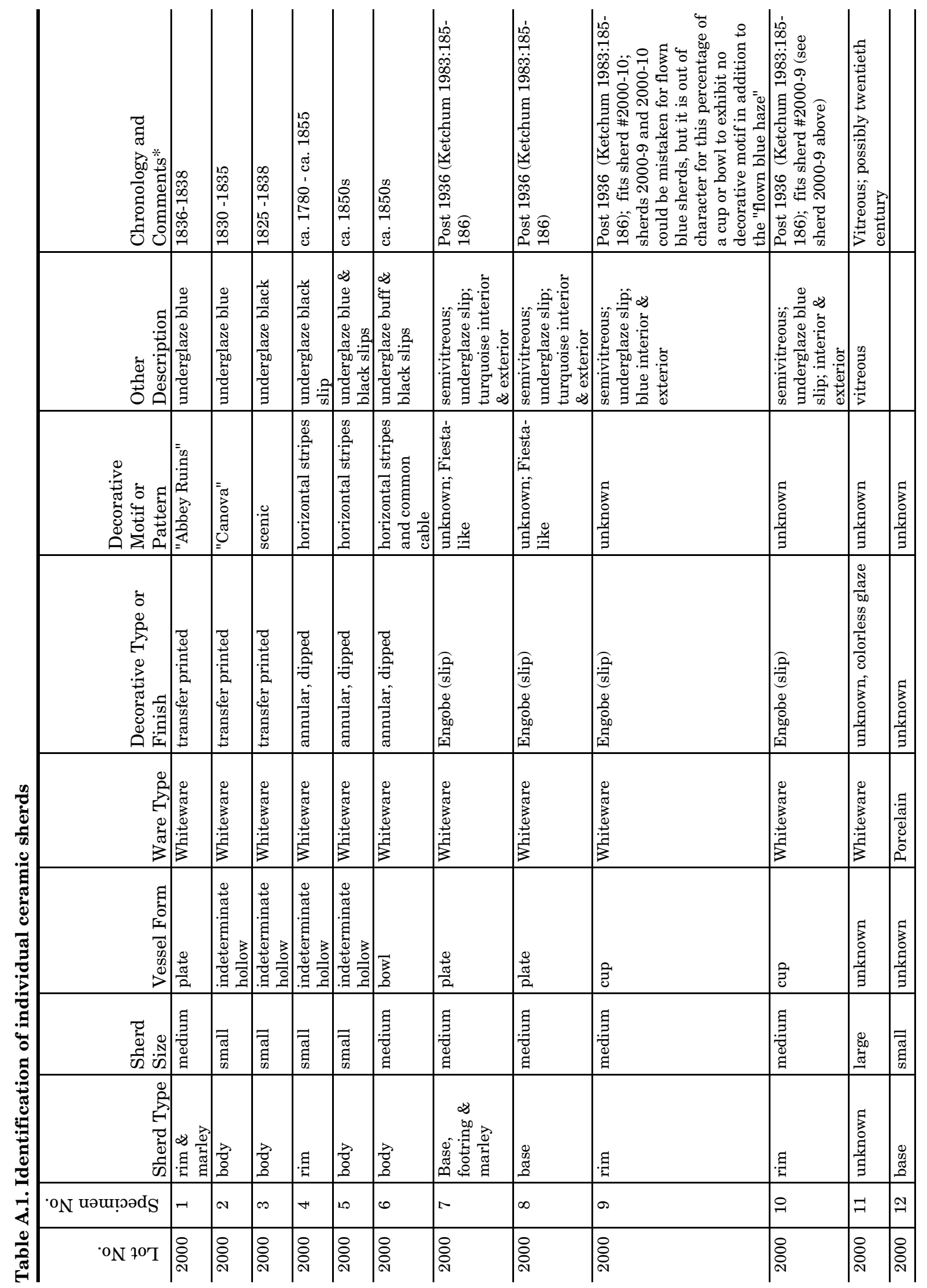




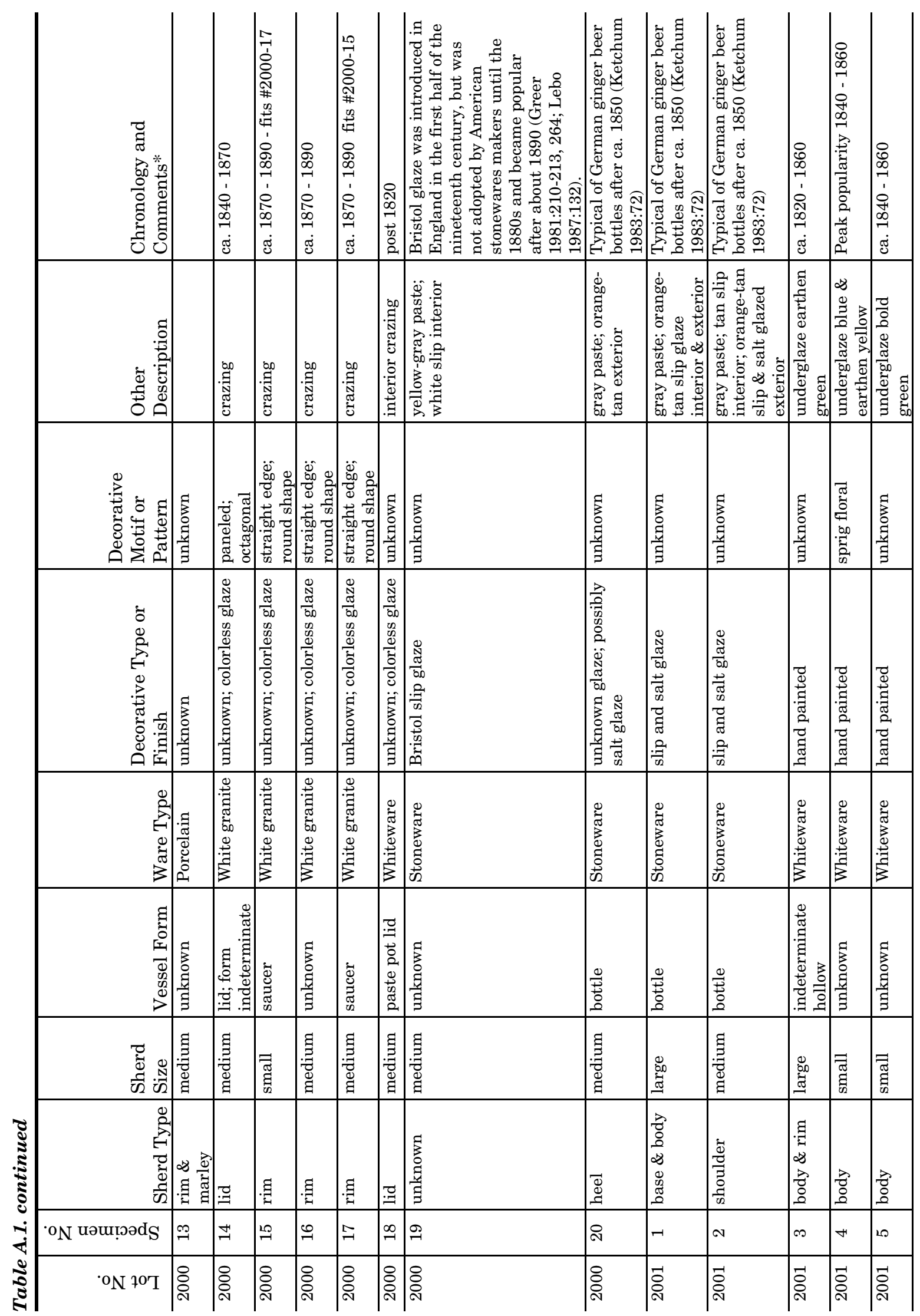




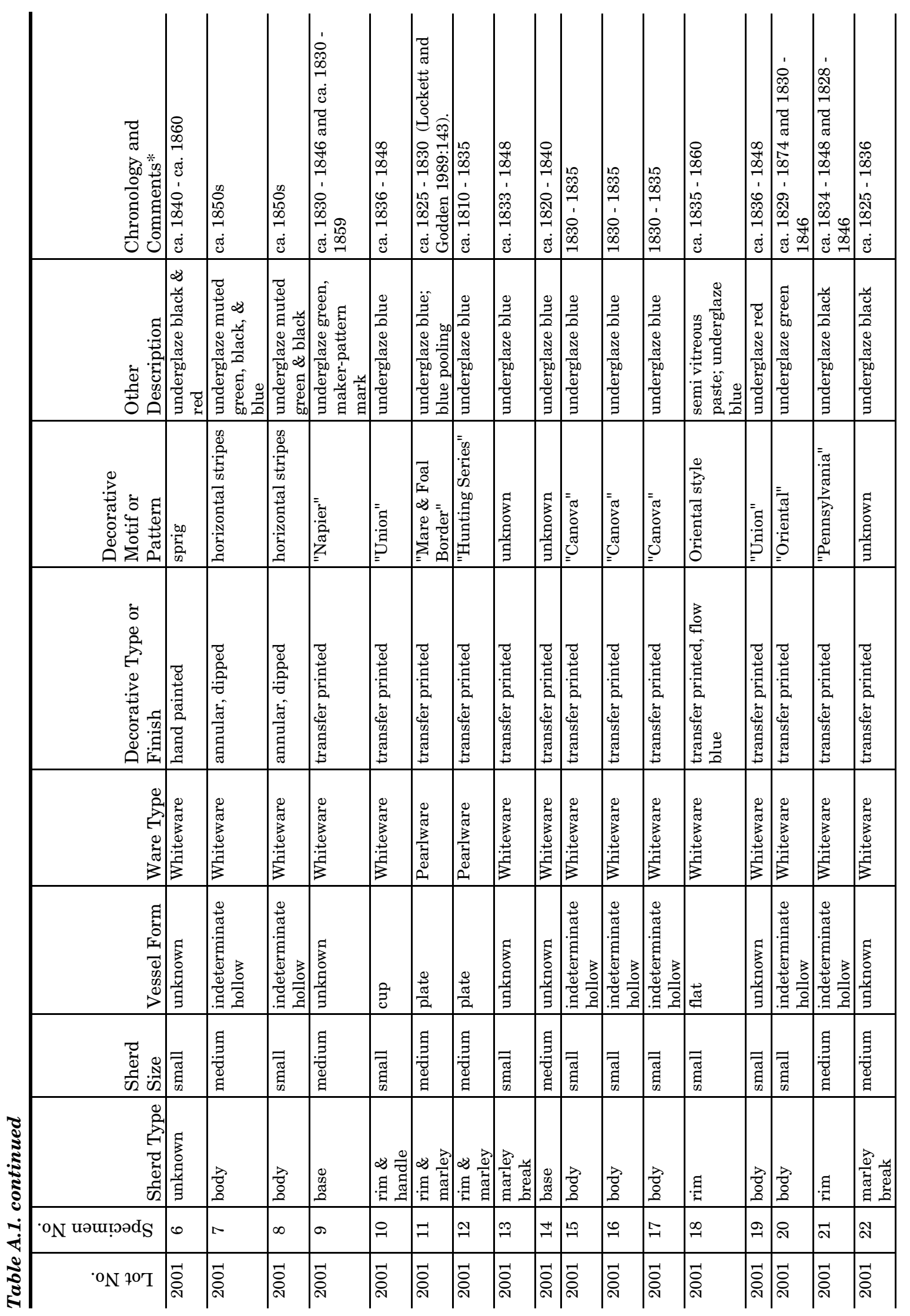




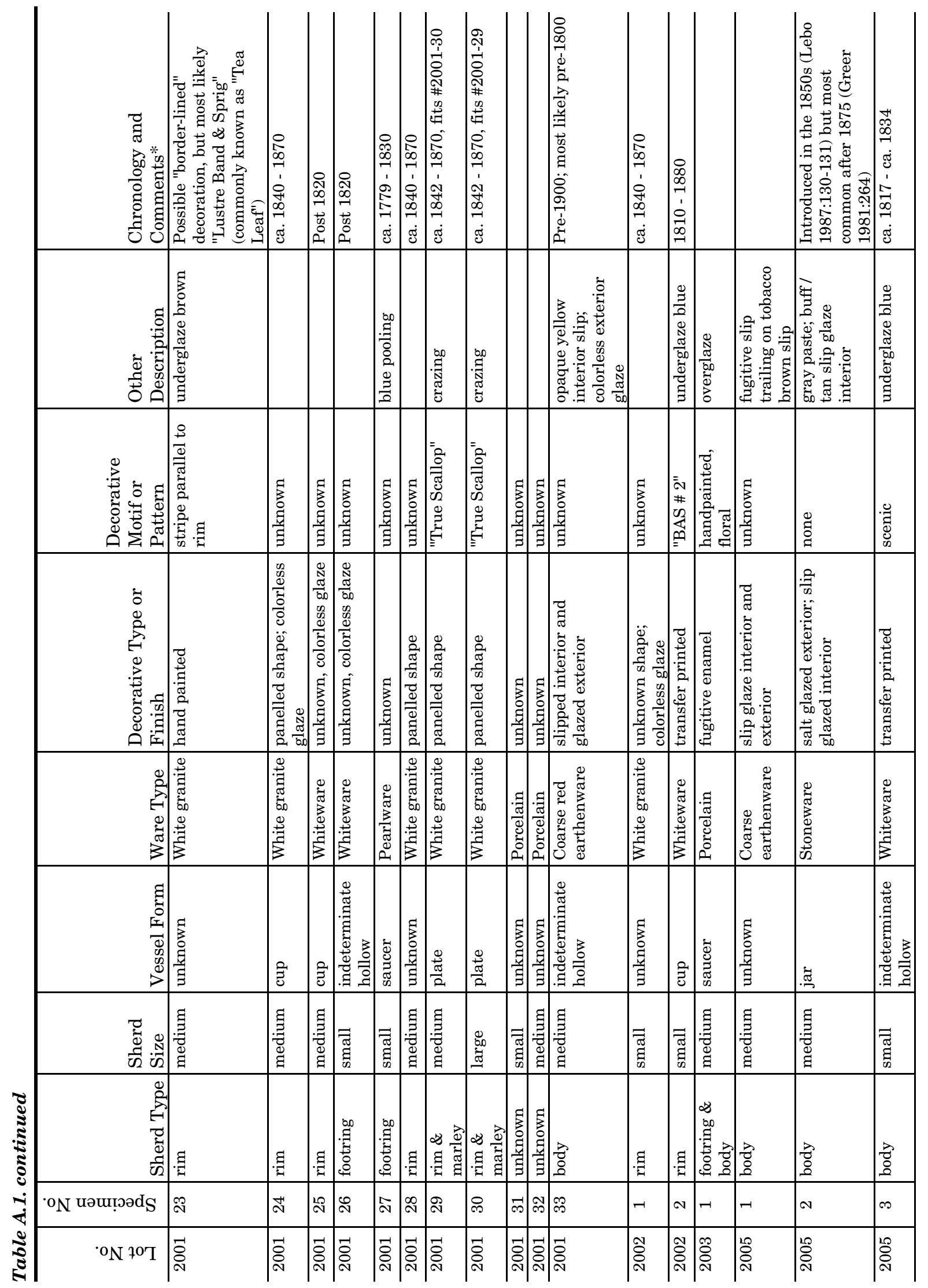


Appendix A: Analysis of Ceramic Vessel Sherds

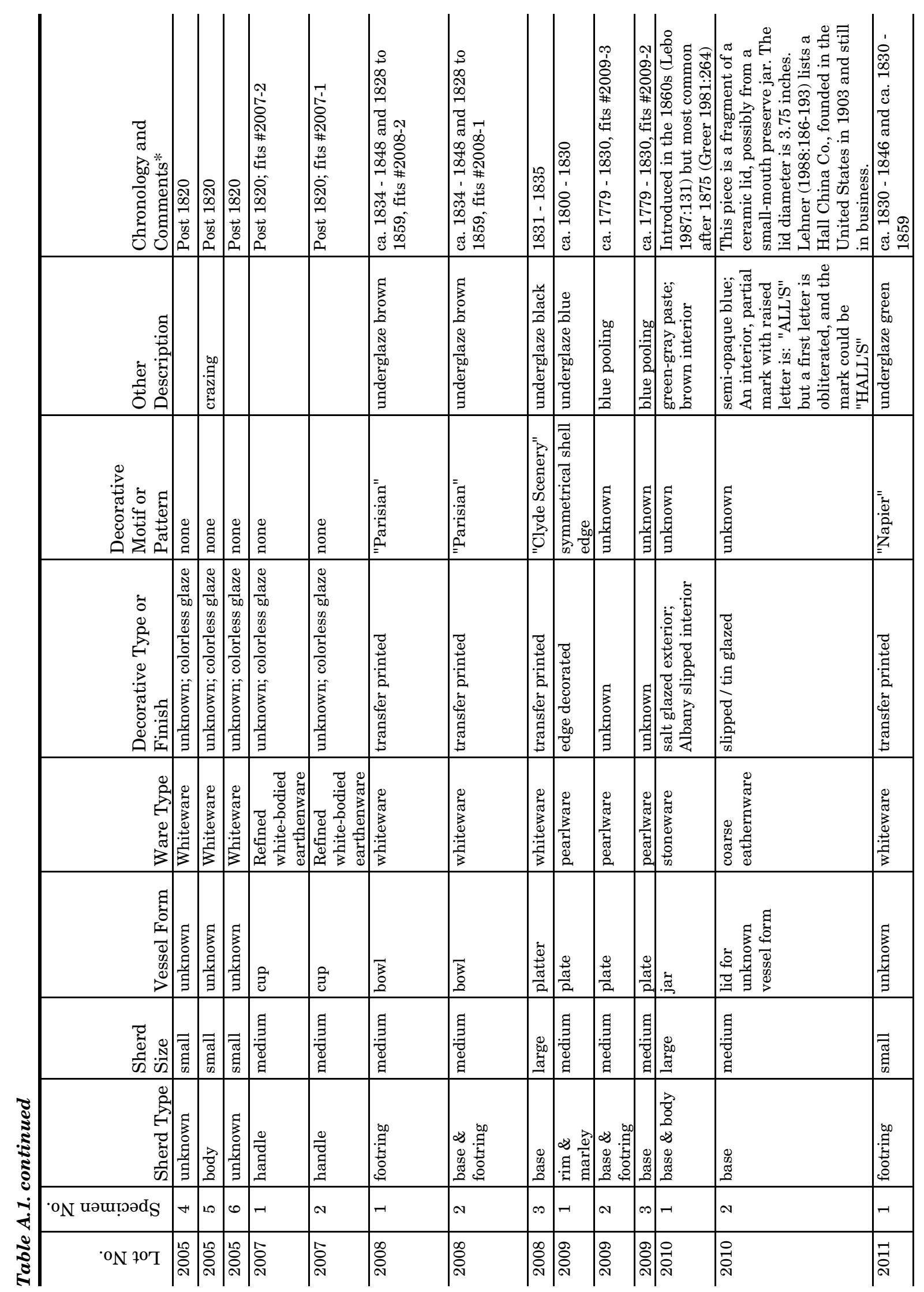




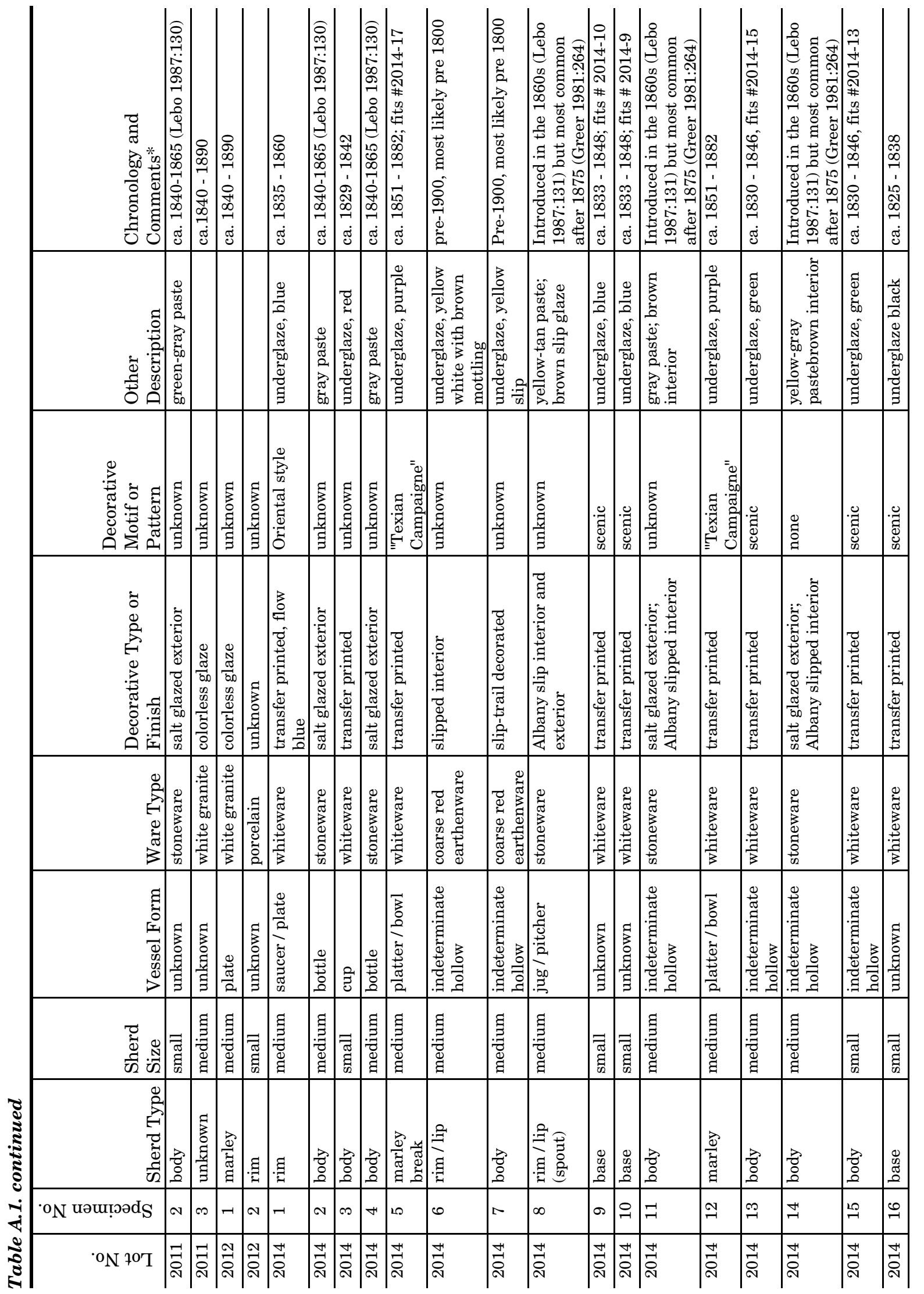




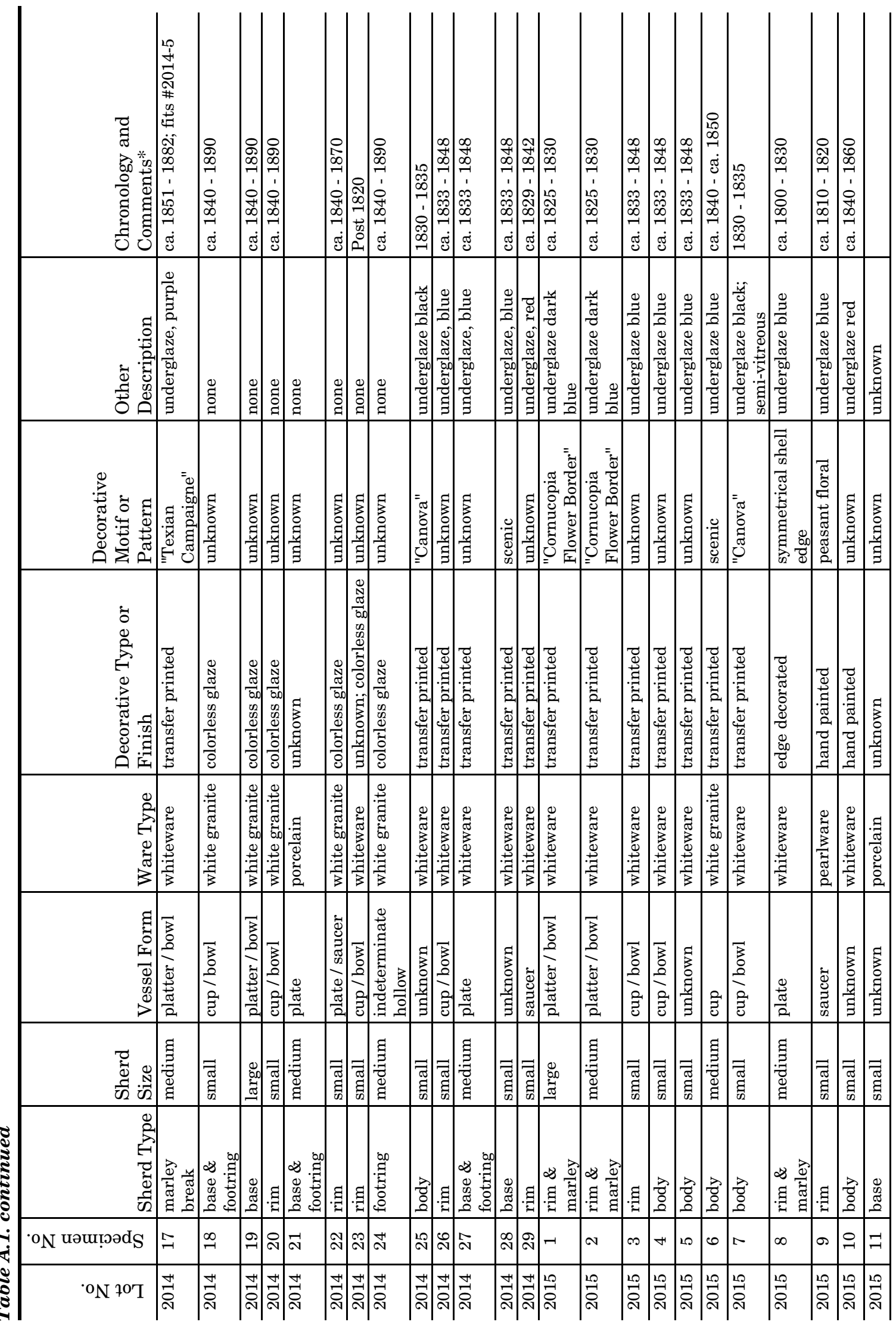




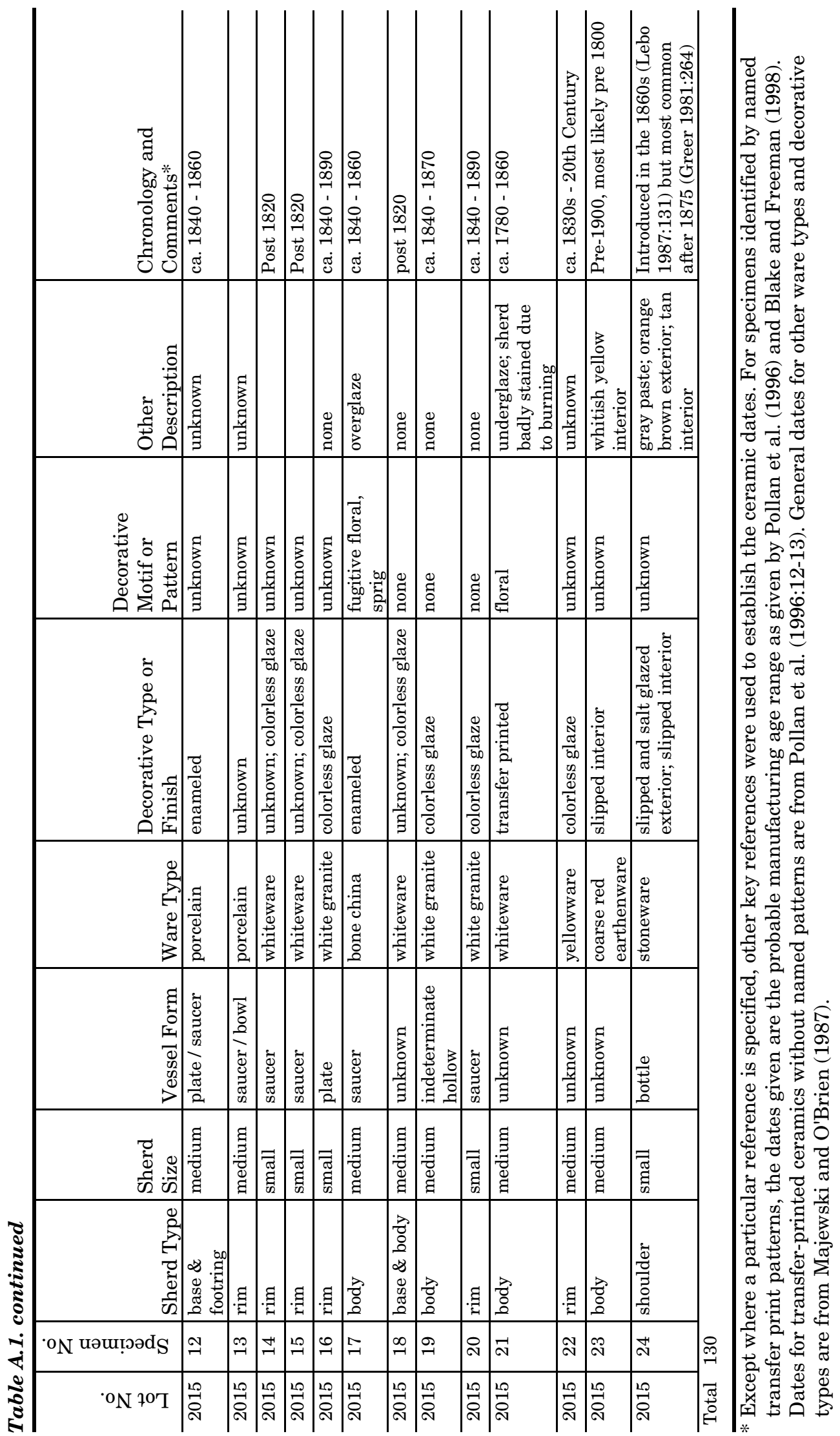


Table A.2. Summary of ceramic ware types and decorations

\begin{tabular}{|c|c|c|}
\hline Ware Type & Decoration & $\begin{array}{l}\text { No. of } \\
\text { Sherds }\end{array}$ \\
\hline Coarse earthenware & various slips and glazes (including redware) & 6 \\
\hline Yellowware & colorless glaze & 1 \\
\hline Stoneware & various slips and glazes (Albany, Bristol, salt) & 13 \\
\hline \multirow[t]{4}{*}{ Pearlware } & hand-painted & 1 \\
\hline & edge-decorated & 1 \\
\hline & transfer-printed & 2 \\
\hline & unknown & 3 \\
\hline Refined white-bodied earthenware & unknown & 2 \\
\hline \multirow[t]{6}{*}{ Whiteware } & transfer printed & 43 \\
\hline & annular-decorated & 5 \\
\hline & shell edge-decorated & 1 \\
\hline & engobe (Fiesta-like) & 4 \\
\hline & hand-painted & 5 \\
\hline & unknown & 11 \\
\hline \multirow[t]{4}{*}{ White granite } & hand-painted & 1 \\
\hline & transfer-printed & 1 \\
\hline & molded shape & 5 \\
\hline & unknown & 14 \\
\hline Bone china & enameled & 1 \\
\hline \multirow[t]{3}{*}{ Porcelain } & enameled & 1 \\
\hline & enameled, hand-painted & 1 \\
\hline & unknown & 8 \\
\hline Total & & 130 \\
\hline
\end{tabular}

Of all the analyzed ceramic specimens, it is notable that relatively few appear to be out of context and not associated with the pre-1875 occupations at Old Velasco. Four sherds that have an engobe slip glaze, two in blue and two in turquoise, appear to represent twentieth-century ceramics that were made after 1936 . In particular, the two turquoise sherds appear similar to the classic brightly colored Fiesta wares that were popular for decades after they were introduced in 1936 (Ketchum 1983:185-186). In addition, the
13 stoneware specimens exhibit a range of different surface treatments, including salt glaze and Albany slip glazes, that were used on imported English ceramics and began to be used on American stonewares in the 1840 s to 1860 s. Glazing of both interiors and exteriors became more common after about 1875 . One stoneware sherd has a Bristol slip glaze, a decorative style that was used on imported English ceramics in the mid-1800s but was not used on American stonewares until the 1880 s. 
Table A.3. Identification of transfer-printed ceramic patterns

\begin{tabular}{l|l|l}
\hline Pattern & Probable Dates of Manufacture* & Reference** \\
\hline Abbey Ruins & 1836 to 1838 & $\begin{array}{l}\text { Blake and Freeman 1998:25; Pollan et } \\
\text { al. 1996:17 }\end{array}$ \\
\hline BAS \#2*** & 1810 to 1880 & Pollan et al. 1996:91 \\
\hline Canova & 1830 to 1835 & Pollan et al. 1996:23-24 \\
\hline Clyde Scenery & 1831 to 1835 & Pollan et al. 1996:29-30 \\
\hline Cornucopia Flower Border & ca. 1825 to 1830 & Pollan et al. 1996:31 \\
\hline Hunting Series & ca. 1810 to ca. 1835 & Pollan et al. 1996:47-48 \\
\hline Mare \& Foal Border & ca. 1825 to 1830 & Lockett and Godden 1989:143 \\
\hline Napier & ca. $1830-1859$ and ca. 1830 to 1846 & $\begin{array}{l}\text { Blake and Freeman 1998:86; Pollan et } \\
\text { al. 1996:56-57 }\end{array}$ \\
\hline Oriental & ca. $1829-1874$ and ca. 1830 to 1848 & $\begin{array}{l}\text { Blake and Freeman 1998:87-89; Pollan } \\
\text { et al. 1996:58 }\end{array}$ \\
\hline Parisian & $1834-1848$ and $1828-1859$ & Pollan et al. 1996:60-61 \\
\hline Pennsylvania & ca. 1828 to 1846 & Pollan et al. 1996:62 \\
\hline Texian Campaigne & 1851 to 1882 & Pollan et al. 1996:76-77 \\
\hline Union & ca. 1836 to 1848 & Pollan et al. 1996:80 \\
\hline
\end{tabular}

* Probable dates of manufacture are from Blake and Freeman (1998) and Pollan et al. (1996) and are derived from comparison with the transfer-printed ceramic type collection from Old Velasco (41BO125) and Quintana (41B0135). They are based primarily on the dates of operation for specific pottery manufacturing firms (see Pollan et al. 1996:12-13).

** All of the identified patterns except one are illustrated and described in transfer-printed ceramic catalogs for Old Velasco (Pollan et al. 1996) and Quintana (Blake and Freeman 1998). The "Mare and Foal" is a border series with various pastoral central views, but it is not represented in the published catalogs for Old Velasco and Quintana.

*** BAS \#2 refers to an unidentified transfer print pattern defined by the Brazosport Archeological Society (see Pollan et al. 1996:12). 


\section{REFERENCES CITED}

Blake, Marie E., and Martha Doty Freeman 1998 Nineteenth-Century Transfer-Printed Ceramics from the Texas Coast: The Quintana Collection. U.S. Army Corps of Engineers, Galveston District.

Dieringer, Ernie, and Bev Dieringer

2001 White Ironstone China Plate Identification Guide 1840-1890. Schiffer Publishing Ltd., Atglen, Pennsylvania.

Greer, Georgeanna

1981 American Stonewares, The Art and Craft of Utiliarian Potters. Schiffer Publishing Ltd., Exton, Pennsylvania.

Gross, W. Sue

1996 Transfer-Printed Earthenwares. In Nineteenth-Century Transfer-Printed Ceramics from the Townsite of Old Velasco (41BO125), Brazoria County, Texas: An Illustrated Catalogue, by Sandra D. Pollan, W. Sue Gross, Amy C. Earls, Johnney T. Pollan, Jr., and James L. Smith, pp. 5-6. U.S. Army Corps of Engineers, Galveston District.

Ketchum, Jr., William C.

1983 The Knopf Collectors' Guides to American Antiquties: Pottery \& Porcelain. Alfred A. Knopf, New York.

Lebo, Susan A.

1987 Local Utilitarian Stonewares: A Diminishing Artifact Category. In Historic Buildings, Material Culture, and People of the Prairie Margin: Architecture, Artifacts, and Synthesis of Historic Archeology, edited by David H. Jurney and Randall W. Moir, pp. 121-142. Richland Creek Technical Series, Vol. V. Archaeology Research Program, Institute for the Study of Earth and Man, Southern Methodist University, Dallas, Texas.

Lehner, Lois

1988 Lehner's Encyclopedia of U.S. Marks on
Pottery, Porcelain \& Clay. Collector Books, Paducah, Kentucky.

Lockett, Terence A., and Geoffrey A. Godden

1989 Davenport China, Earthenware \& Glass, 1794-1887. Barrie \& Jenkins, London.

Majewski, Teresita, and Michael J. O'Brien

1984 An Analysis of Historical Ceramics from the Central Salt River Valley of Northeast Missouri. Cannon Reservoir Human Ecology Project, Vol. 2. Publications in Archaeology No. 3, American Archaeology Division, Department of Anthropology, University of Missouri-Columbia.

1987 The Use and Misuse of Nineteenth-Century English and American Ceramics in Archaeological Analysis. In Advances in Archaeological Method and Theory, Vol. 11, edited by Michael J. Schiffer, pp. 97-209. Academic Press, New York.

Pollan, Sandra D., W. Sue Gross, Amy C. Earls, Johnney T. Pollan, Jr., and James L. Smith

1996 Nineteenth-Century Transfer-Printed Ceramics from the Townsite of Old Velasco (41B0125), Brazoria County, Texas: An Illustrated Catalogue. U.S. Army Corps of Engineers, Galveston District.

Rollins, Sarah Finch Maiden

1983 Texian Campaine Ware in The Magazine Antiques. Brant Publications, Inc., New York.

Wetherbee, Jean

1980 A Look at White Ironstone. Wallace-Homestead Books Company, Des Moines, Iowa.

1985 A Second Look at White Ironstone. WallaceHomestead Books Company, Lombard, Illinois.

1996 White Ironstone: A Collector's Guide. Antique Trader Books, Dubuque, Iowa. 



\title{
APPENDIX B: Analysis of Faunal Remains
}

\author{
Brian S. Shaffer
}





\section{INTRODUCTION}

The broad goals of the analysis of the vertebrate faunal remains from the Village of Surfside Beach boat ramp project data recovery are to provide taxonomic identifications and to identify cultural patterns as reflected by the vertebrate remains. These patterns include identifying subsistence, economic scaling as reflected by cuts of meat, and the exploitation of domestic and wild species.

\section{METHODS}

Specimens described here were identified using comparative skeletal materials of identified taxa with the aid of osteological guides by Balkwill and Cumbaa (1992) and Olsen (1960) for cattle and bison. Data recorded includes provenience, taxon, element, portion of element, side, aging, basic taphonomic information and butchery. The taphonomic information included weathering, breakage, and burning. Butchering data includes cut types, locations, and directions. Unique observations, such as pathological disorders, were recorded in a comments field. The attributes for each bone examined in this analysis are presented in a table at the end of the appendix.

Quantification of the Velasco faunal remains followed two methods, number of identified specimens (NISP), and minimum number of individuals (MNI). NISP is simply the specimen counts for the assemblage and for the identified taxa (Table B.1). MNIs were calculated based on the most frequent element for each identified age class for each taxon for the site as a single aggregate (Table B.2) and by features (Table B.3).

While recording attributes may seem straightforward, problems of identification extend beyond taxonomic identification. For example, Figure B.1 shows the cut surface of a Bos/Bison femur that appears to show saw marks oriented in two directions. The bone is seen from the perspective of looking toward the proximal end. In the middle of the image is a white angle roughly paralleling the two directions of possible saw marks. The long arrow on the left side points to a hinge feature on the bone that is raised above the rest of the cut surface. The short arrow shows the clearest striation of

Table B.1. Taxa recovered by number of identified specimens (NISP) and minimum number of individuals (MNI) for sample as single aggregate

\begin{tabular}{l|l|c|c}
\hline Taxon & Common Names & NISP & MNI* \\
\hline Vertebrata & Vertebrates & 2 & \\
\hline Osteichthyes (Medium) & Medium bony fish & 1 & 1 \\
\hline Gallus gallus & Domestic chicken & 1 & 1 \\
\hline Mammalia (Medium/large) & Canid/deer-sized mammals & 90 & \\
\hline Mammalia (Large/very large) & Deer/bison-sized mammals & 298 & \\
\hline Artiodactyla (Medium) & Deer/pronghorn-sized ungulates & 1 & \\
\hline Artiodactyla (Large) & Bison/cow-sized ungulates & 1 & \\
\hline cf. Odocoileus sp. & Deer & 1 & 1 \\
\hline Bos sp. & Cattle & 21 & \\
\hline cf. Bos sp. & Cattle & 17 & \\
\hline Bos / Bison & Cattle/bison & 73 & \\
\hline cf. Bos / Bison & Cattle/bison & 7 & \\
\hline Ovis / Capra & Sheep/goat & 516 & \\
\hline Total NISP & & 3 & 2 \\
\hline
\end{tabular}

* MNI calculation based element (and portion thereof) duplication and aging characteristics.

** Taxa identified as Bos sp., Bos / Bison, cf. Bos/Bison, and large artiodactyla are combined for calculation of MNI given that no bison were identified in the assemblage to necessitate separate calculation and since the taxa are of fairly comparable size and butchered as comparable types of animals. The large Mammalia category is probably composed primarily of cattle remains as well, but these remains, when combined with cattle data, did not alter the MNI calculations. 
Archeological Survey of a Portion of Old Velasco

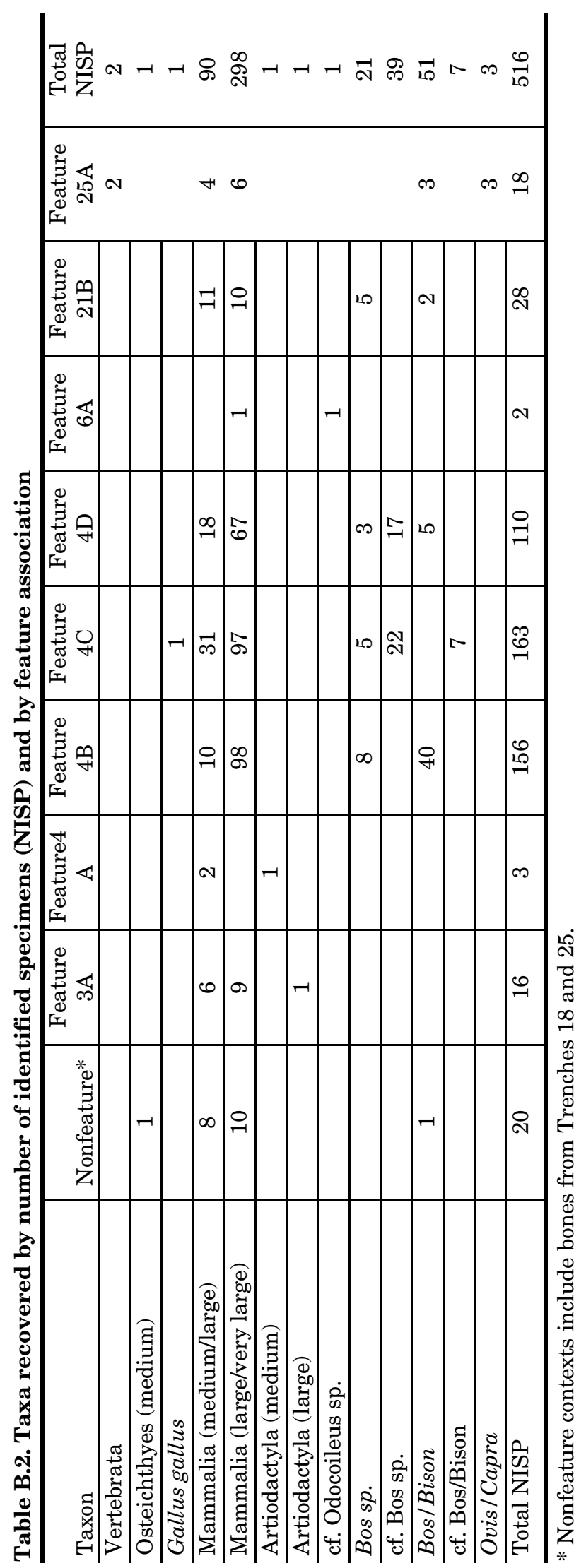


Table B.3. Taxa recovered by minimum number of individuals (MNI) and by feature association

\begin{tabular}{|c|c|c|c|c|c|c|c|c|c|}
\hline \multirow[b]{2}{*}{ Taxon } & \multicolumn{9}{|c|}{ Nonfeature and Feature MNIs } \\
\hline & None & $3 \mathrm{~A}$ & $4 \mathrm{~A}$ & $4 \mathrm{~B}$ & $4 \mathrm{C}$ & $4 \mathrm{D}$ & $6 \mathrm{~A}$ & $21 \mathrm{~B}$ & $25 \mathrm{~A}$ \\
\hline \multicolumn{10}{|l|}{ Vertebrata } \\
\hline Osteichthyes (medium) & 1 & & & & & & & & \\
\hline Gallus gallus & & & & & 1 & & & & \\
\hline \multicolumn{10}{|c|}{ Mammalia (medium/large) } \\
\hline \multicolumn{10}{|c|}{ Mammalia (large/very large) } \\
\hline \multicolumn{10}{|l|}{ Artiodactyla (medium) } \\
\hline \multicolumn{10}{|l|}{ Artiodactyla (large) } \\
\hline cf. Odocoileus sp. & & & & & & & 1 & & \\
\hline Bos sp. & 1 & & & 4 & 4 & 3 & & 2 & 2 \\
\hline \multicolumn{10}{|l|}{ cf. Bos sp. } \\
\hline \multicolumn{10}{|l|}{ Bos / Bison } \\
\hline \multicolumn{10}{|l|}{ cf. Bos / Bison } \\
\hline Ovis / Capra & & & & & & & & & 2 \\
\hline Total & 2 & 0 & 0 & 4 & 5 & 3 & 1 & 2 & 4 \\
\hline
\end{tabular}

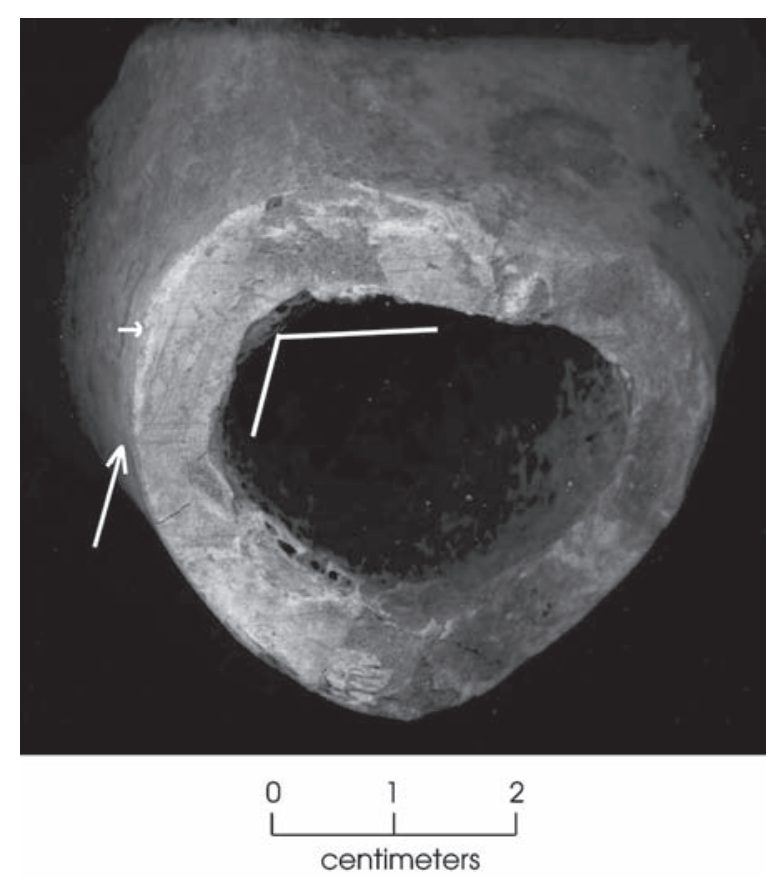

Figure B.1. Cut surface of a Bos femur from Feature 25A. This specimen has hand saw marks coming from two different directions.

the cross-cut marks traversing the bone and present on the raised hinge.

The significance of and problem of the cross striations that appear to be from cut marks are that they are not spaced as saw marks normally would be spaced. There should be cross striations from sawing across the entire surface. Additionally, the hinge is critical. A hinge is a sort of ridge that is sometimes produced when a bone (or wood for that matter) is cut nearly completely across. When the last remaining bone snaps, it often leaves a raised ridge or hinge on one side and a corresponding negative feature on the other. The presence of a hinge indicates that the bone was first cut toward the hinge at the point where the bone finally snapped. This specimen, though has what appears to be the cross saw marks on the original cut surface and also on the raised hinge, the noted striation on the hinge traversing the rest of the cut surface, in spite of the hinge being raised above the rest of the cut surface. Given that the marks do not look like typical saw marks and that some of the cross striations span surface regardless of elevation, it is not reasonable to conclude that the bone was cut by a saw. As indicated by the general regularity of the surface, the bone was probably chopped by an implement such as a cleaver or an ax, but the process that created the striations is not determined.

Dark brown staining of much of the faunal sample also hindered identification of burning in some cases (Figure B.2). As a result, some charred (burned black or brown) bones may not have been identified as they blended in with the stained bone. 

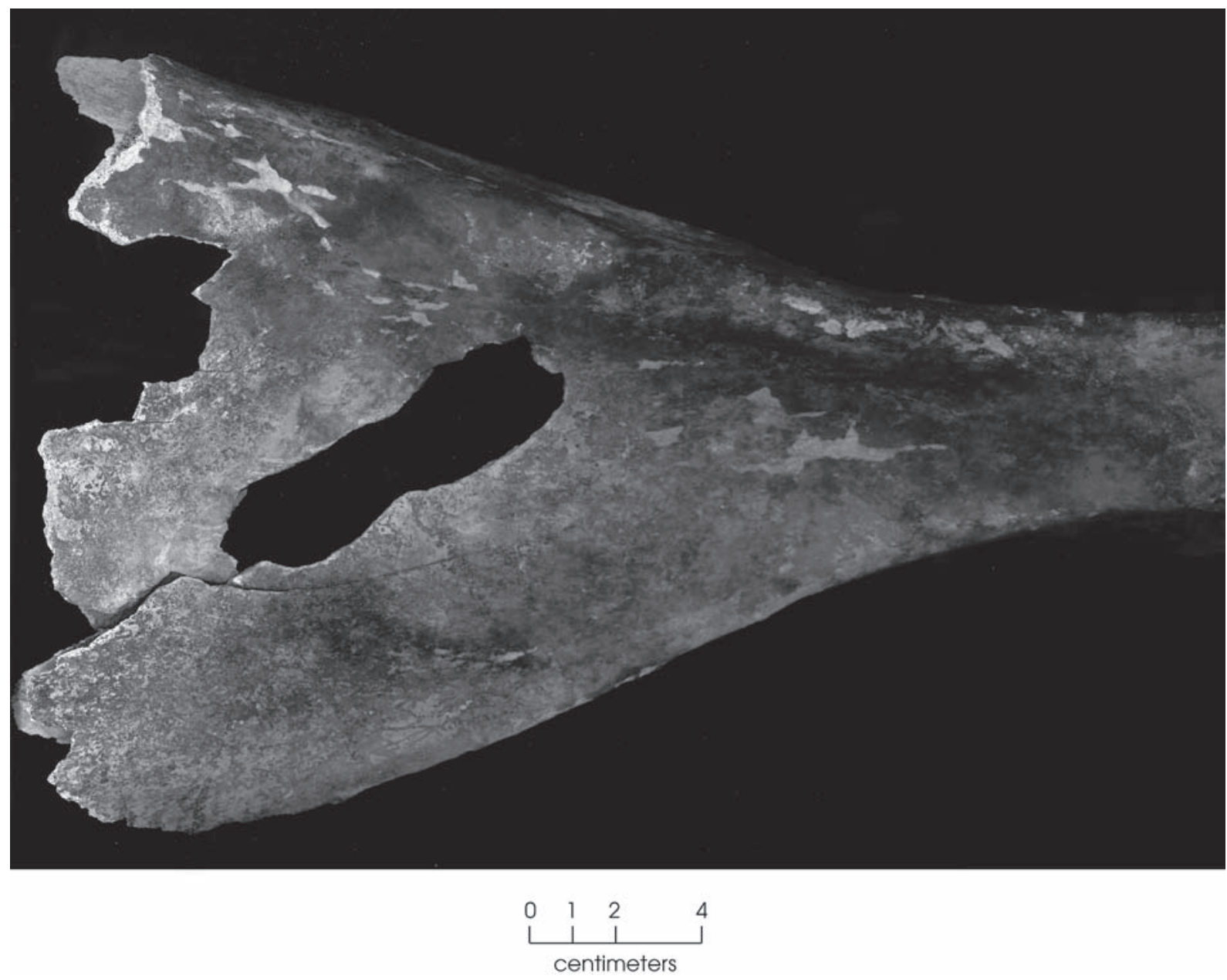

Figure B.2. Bos scapula from Feature 4D. This specimen exhibits dark coloration due to mineral staining from being saturated in groundwater. It also exhibits postdepositional damage because the bone is friable due to dissolution.

\section{TAPHONOMY}

Many factors have acted on the faunal assemblage since the time of death of the animals. Weathering, defined as the effects of exposure to the environment, was minimal and did little damage to the overall sample. In fact, there was no bone identified with evidence of weathering produced as a result of surface exposure.

The most destructive taphonomic factor in the assemblage was fragmentation. Only 25 specimens (5 percent) were unbroken, and they were all carpals and tarsals of Bos sp., Bos / Bison, or large mammal (probably Bos / Bison). Most of the sample (415, or 80 percent) is represented by angular fracturing. This means that the bone had lost its collagen before being bro- ken (Johnson 1985). Thus, angularly fractured bone usually would not have been broken this way during the handling, processing, or consumption of the animal and probably occurred sometime after initial exploitation. Spiral fracturing that is indicative of fresh bone breakage (Johnson 1985:172) was infrequent, with 76 specimens (15 percent of total sample) exhibiting this form of breakage.

Burning was identified in very low amounts. Twenty-seven specimens were identified as burned, with 21 being charred (incompletely burned, usually black or brown) and six being calcined (more completely burned, white in color). The process of burning will destroy collagen (Black 1989; Shipman et al. 1984) and will expedite the angular fragmentation of bone. 
Direct evidence of butchering as reflected by the presence of cut marks was present on 75 specimens (15 percent). These were identified on mammals only, but of course the assemblage is heavily weighted with mammals. Butchering is discussed below. At this time, however, only butchery appears to have been completed by non-saw butcher tools such as knifes, cleavers, and/or axes.

Another process impacted the assemblage and has been mentioned, in part. Dark brown staining on much of the assemblage appears to be the result of mineral or chemical staining as is sometimes found in submerged or occasionally submerged faunal assemblages such as those recovered from wells or some water habits such as points. If not being mineralized by the process of being wet and being replaced by ground minerals, bone may suffer dissolution instead. With dissolution, pitting or other evidence would be expected but was not identified. However, much of the stained bone was highly friable, flaked readily during handling, and did not appear to have the density or weight of undamaged bone. Such damage can be seen in Figure B.2. In Shaffer's personal experience, bones of similar condition have been recovered from manmade cattle water tanks in which the bones were found partially submerged. Given the near or belowsea-level location of the fauna sample recovered, it is likely that the staining and friable condition was produced by long-term exposure in a wet environment. As an aside, thinner bones such as flat bones like scapulae and ribs suffered as a result of this process much more than denser bones such as long bones and podials.

\section{Taxonomic Representation}

As seen in Table B.1, the assemblage is almost entirely composed of mammalian remains. The only exceptions are specimens including two vertebrata, one fish, and one chicken. The rest of the assemblage is dominated by cattle-sized taxa with some deer- and sheep/ goat-sized taxa as well. The predominance of such large specimens may be the result of selective recovery in the field, but it also may reflect the original sample composition, especially for individual features. If the composition is the product original site context, such a composition might be expected from some sort of specialty locality such as might be associated with initial or secondary butchery processes of livestock. As such, taxa such as fish, bird, and most mammalian wildlife would not be expected to be common. This idea will be reviewed further in the butchery section.

In comparing the MNIs noted in Tables B.1 and B.3, Table B.3 indicates more animals. This is a product of how the sample is aggregated. When each feature is treated as a separate aggregate and the MNI from each aggregate is tallied together, it is not uncommon for the MNI total for the site to appear to increase. For example, the Bos sp. (all Bos-related identifications) MNI tally for the site is 6 , but 15 when each feature is tallied separately and then added together. The MNI tally for Ovis / Capra did not change because Ovis/Capra bones were only recovered from one feature within the site so the tally did not change. Neither perspective is in error, only different views of the data.

\section{Butchery}

The butchered remains provide some interesting insight into the assemblage composition (Table B.4). The butchered cow bones represent mainly the spine, ribs, and legs, and to a lesser extent the shoulder and rump. Missing from the assemblage were signs of obvious formal butchered cuts, even though much of the assemblage is butchered. Depending on the process, all of the butchery may have been done in one location, or it may have been staged or jobbed. For example, there may have been primary rendering of animal carcasses by butcher houses for distribution as sides or quarters of animals. These may have gone to end users for complete butchery and consumption or to an intermediate middleman operation such as a butcher shop, where the remains would be cut into the final formal cuts and then sold/distributed to customers for consumption elsewhere. With the recovery of refuse such as animal remains, such distinctions are not always possible. In this case, however, there is an obvious pattern.

First, missing from the assemblage are many of the least useful portions of the carcass for purposes of human consumption. Aside from a single lower incisor, no cranial elements were recovered. Also missing are caudal vertebrae and toes. In short, this is what would be expected of remains having been through a primary butcher process elsewhere. 
Table B.4. Bos sp. and Bos sp.-sized cut bone by feature

\begin{tabular}{|c|c|c|c|c|c|c|c|c|c|}
\hline \multirow[b]{2}{*}{ Element } & \multicolumn{9}{|c|}{ Nonfeature and Feature Cut NISPs } \\
\hline & None & $3 \mathrm{~A}$ & $4 \mathrm{~A}$ & $4 \mathrm{~B}$ & $4 \mathrm{C}$ & $4 \mathrm{D}$ & $6 \mathrm{~A}$ & $21 \mathrm{~B}$ & $25 \mathrm{~A}$ \\
\hline Thoracic vertebra & & & & 4 & 4 & 10 & & & \\
\hline Lumbar vertebra & & & & & & & & & 1 \\
\hline Humerus & & & & 5 & 1 & & & & \\
\hline Scapula & & & & 6 & & 2 & & & \\
\hline Radius & & & & 5 & & & & & \\
\hline Ulna & & & & 2 & 1 & & & & \\
\hline Pelvis & & & & & 1 & & & & \\
\hline Femur & & & & 1 & 1 & 3 & & 1 & \\
\hline Tibia & & & & & & & & 2 & 2 \\
\hline \multicolumn{10}{|l|}{ Podial } \\
\hline Rib & 1 & 1 & & 1 & & 4 & & & \\
\hline Long bone & & & & 3 & 1 & & & 2 & \\
\hline Vertebra & & & & 1 & 1 & 2 & & & \\
\hline Bone & & 1 & & & & 5 & & & \\
\hline Total & 1 & 2 & 0 & 28 & 10 & 26 & 0 & 5 & 3 \\
\hline
\end{tabular}

Second, as noted above, no formal end consumer cuts were identified. Had this assemblage been the remains of meals, then formal or standard cuts should have been apparent in the bone present. For example, short ribs or ribs cut on both ends, usually 3-6 inches apart, were not recovered. In fact, aside from a couple of irregular pieces, there were no specimens with parallel cuts on opposite ends such as might be found in short ribs, rib plates, steaks (usually less than one inch thick between parallel cuts), round cuts, loin cuts, or roast cuts. None of these meat cuts is represented.

Of the cut bones present, many are nonmeaty portions such as podials, distal ends of the tibia, and radius-ulna. The heads of femora, tibia, and humeri are present with cut marksportions that could be used for generalized cooking such as for use as roasts, but they tend to be irregular in shape. There is no evidence of butchering of these end cuts.

Another interesting aspect showed up in Feature 4D. This feature contained the longest sections of ribs, identified as very large mammal, similar to Bos sp. Of the 31 ribs found in the feature, only four were butchered. The longer ribs would appear to be partially processed, but they definitely had not been processed
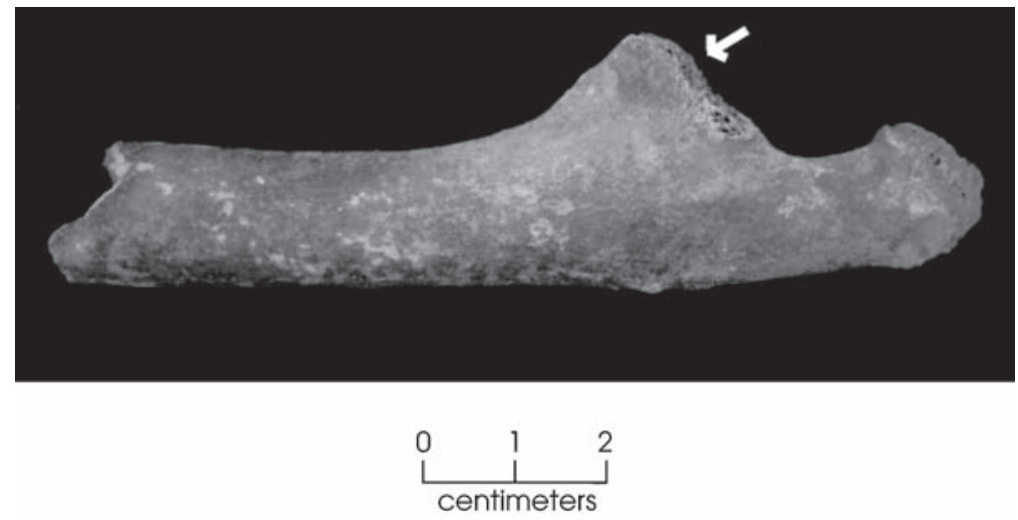

Figure B.3. Probable Bos rib from Feature 4D. This specimen exhibits a pathological bone growth (an enthesophyte) at the point where tendons connect to the bone. for end consumer consumption.

\section{Pathology}

In the small sample, one pathological specimen was identified (Figure B.3). It is a large mammal rib, probably Bos sp., given its size and the context in which it was recovered. A raised triangular protuberance is present on the rib. This is the enthesophyte-in this case, a bone growth at the point of attachment of connective tissue such as a tendon. 


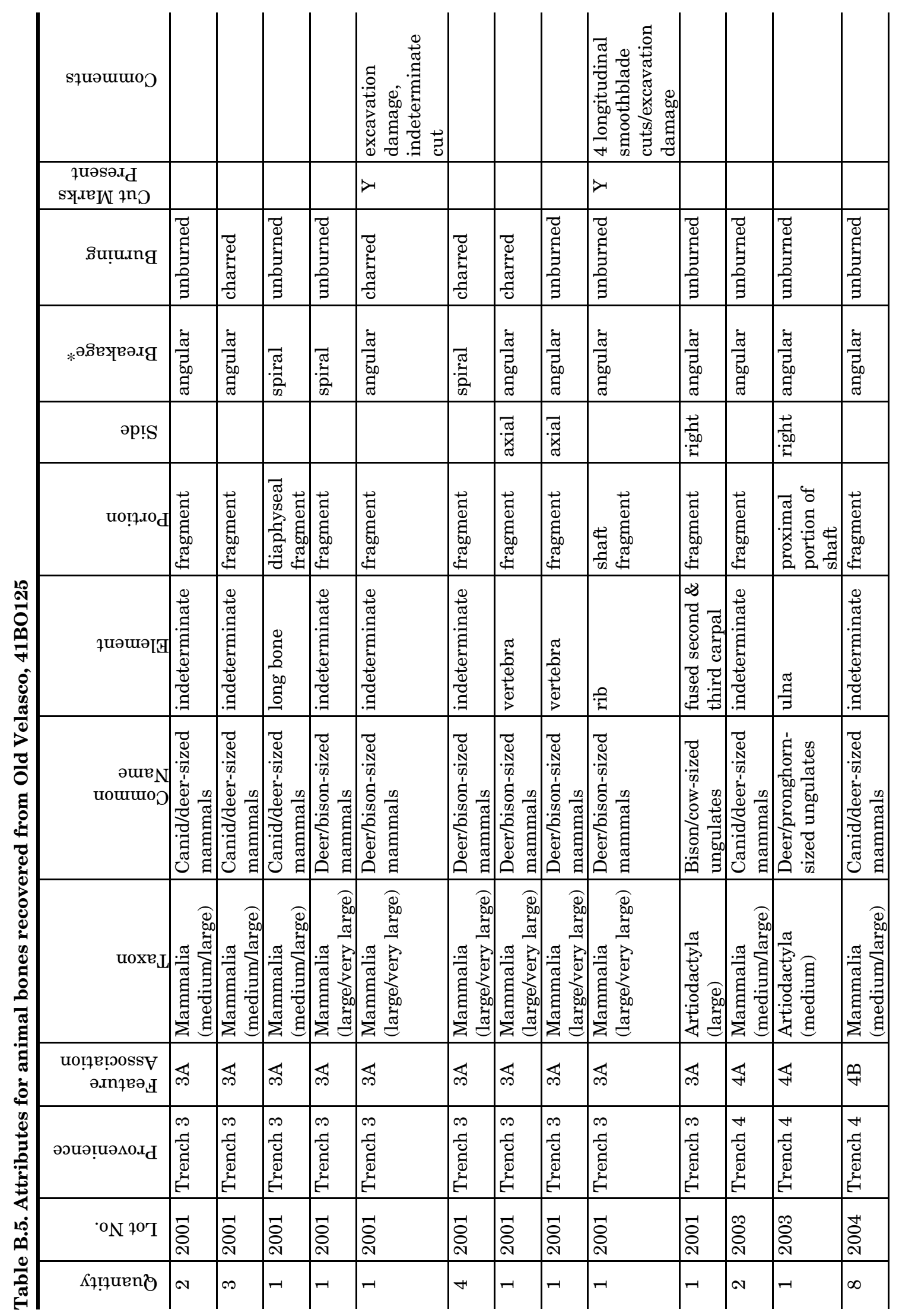




\begin{tabular}{|c|c|c|c|c|c|c|c|c|c|c|c|c|c|c|c|}
\hline squәшuо $\supset$ & 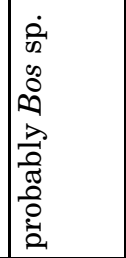 & & & & & & 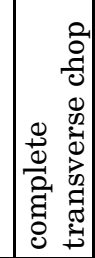 & & & 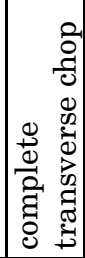 & & 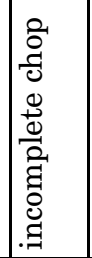 & & & \\
\hline 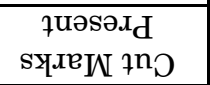 & & & & & & & $>$ & & & 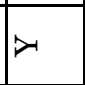 & & 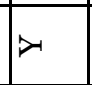 & & & \\
\hline suṭu.nng & 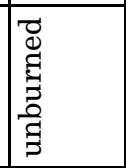 & 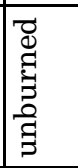 & 总 & 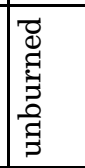 & 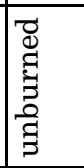 & 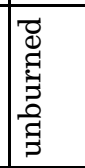 & 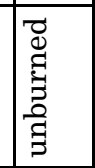 & 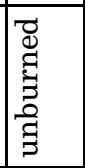 & 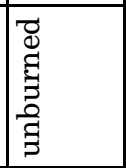 & 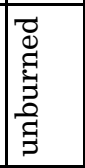 & 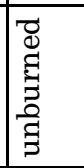 & 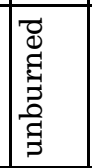 & 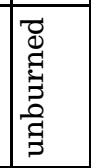 & 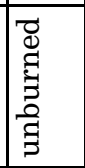 & 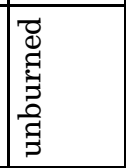 \\
\hline 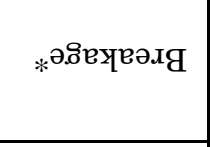 & 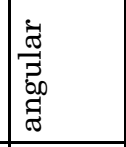 & 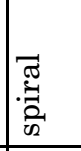 & 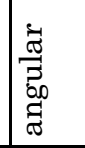 & 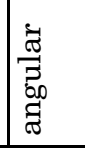 & 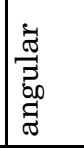 & 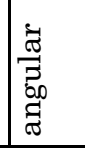 & 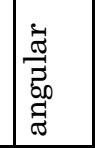 & 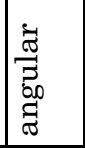 & 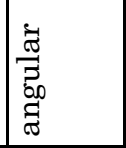 & 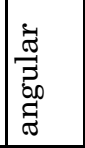 & 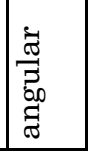 & 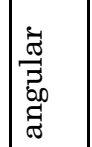 & $\begin{array}{l}\tilde{\sigma} \\
\vec{\Xi} \\
\tilde{\sigma} \\
\tilde{\sigma} \\
\tilde{\sigma}\end{array}$ & 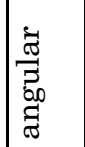 & 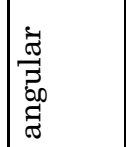 \\
\hline әр!S & & & & & 丞 & 褐 & 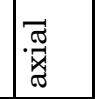 & 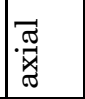 & 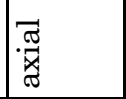 & 丞 & 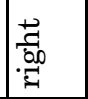 & & & & \\
\hline uo!̣.70 $\mathrm{d}$ & 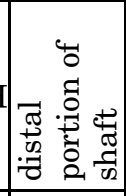 & 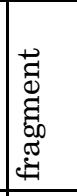 & 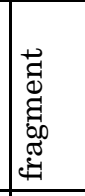 & 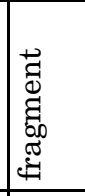 & 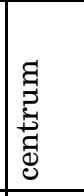 & 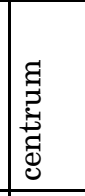 & 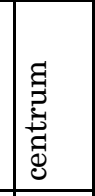 & 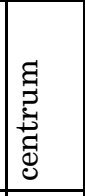 & 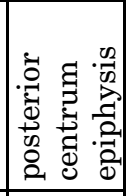 & 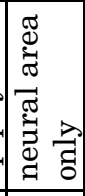 & 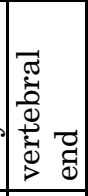 & 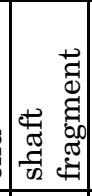 & 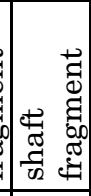 & 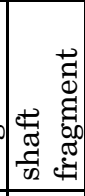 & 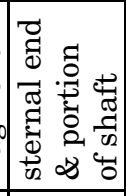 \\
\hline ұиәшәเ田 & $\frac{\pi}{\exists}$ & 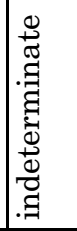 & 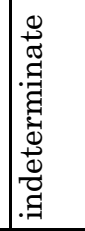 & 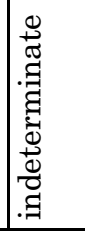 & 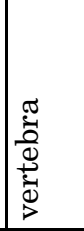 & 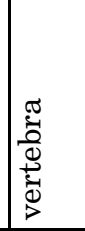 & 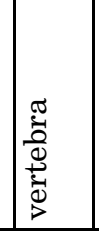 & 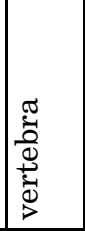 & 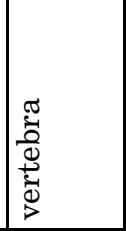 & 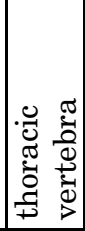 & 을 & 을 & 유 & 을 & 음 \\
\hline $\begin{array}{r}\text { әше } N \\
\text { uowumo }\end{array}$ & 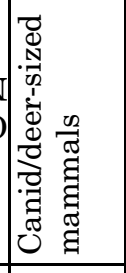 & 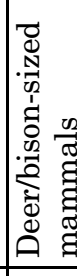 & 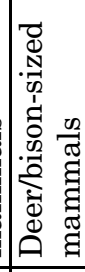 & 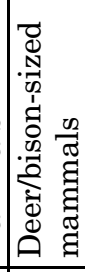 & 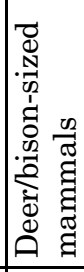 & 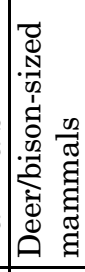 & 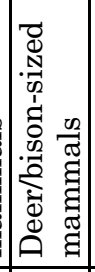 & 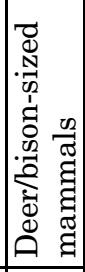 & 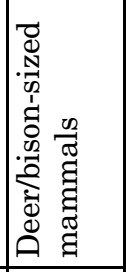 & 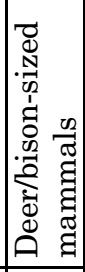 & 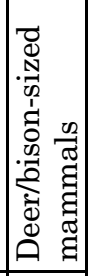 & 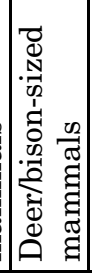 & 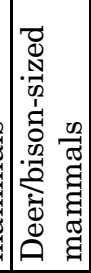 & 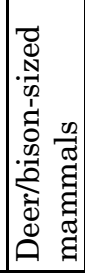 & 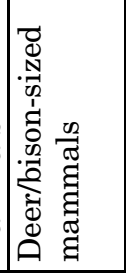 \\
\hline $\operatorname{uoxe}_{\mathrm{L}}$ & 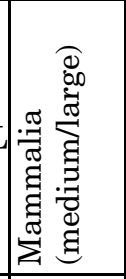 & 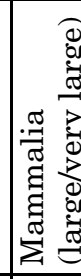 & 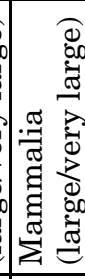 & 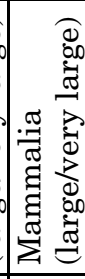 & 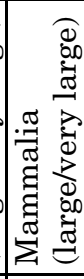 & 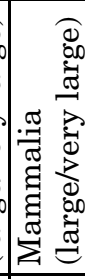 & 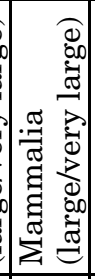 & 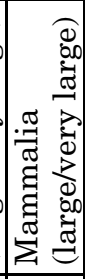 & 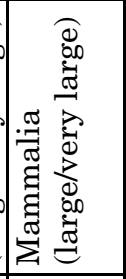 & 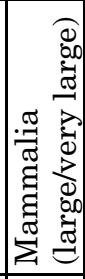 & 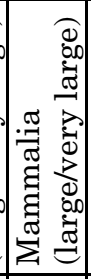 & 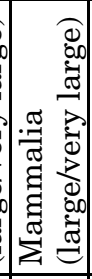 & 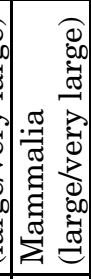 & 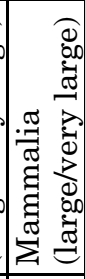 & 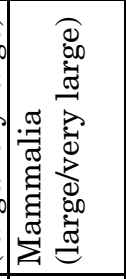 \\
\hline 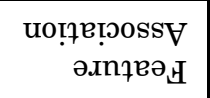 & $\mathscr{F}$ & $\not$ & $\mathscr{F}$ & $\mathscr{F}$ & $\mathscr{F}$ & $\mathscr{F}$ & $\mathscr{F}$ & $\mathscr{F}$ & $\mathscr{f}$ & $\mathscr{F}$ & $\mathscr{F}$ & $\mathscr{F}$ & $\mathscr{F}$ & $\mathscr{f}$ & $\mathscr{f}$ \\
\hline 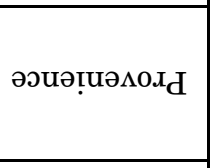 & 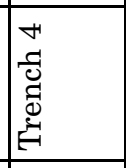 & 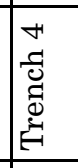 & 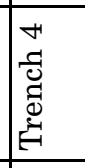 & 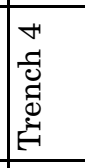 & 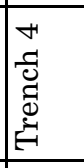 & 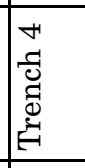 & 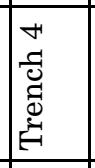 & 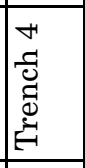 & 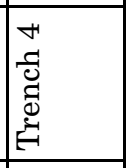 & 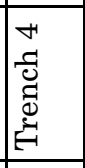 & 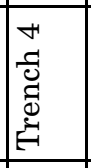 & 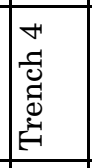 & 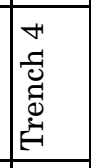 & 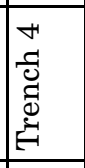 & 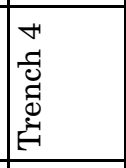 \\
\hline${ }^{\circ} \mathrm{N} 7^{\circ} \mathrm{T}$ & ষ্ণ & 苍 & 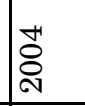 & 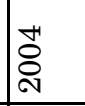 & 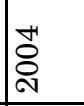 & 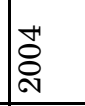 & 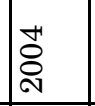 & 离 & 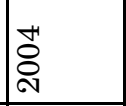 & 离 & 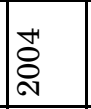 & 苍 & 苍 & 苍 & 苍 \\
\hline Кฺฺฺนеกช & o & 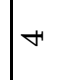 & $\mid-1$ & శ్ & 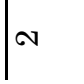 & -1 & $\mid-1$ & -1 & $\mid \neg$ & -1 & -1 & -1 & ஜి & $\infty$ & $\mid-$ \\
\hline
\end{tabular}




\begin{tabular}{|c|c|c|c|c|c|c|c|c|c|c|c|c|c|c|c|c|c|c|}
\hline squәшuо & 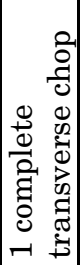 & 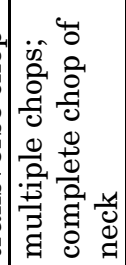 & 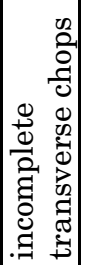 & 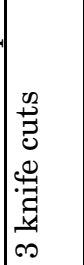 & & 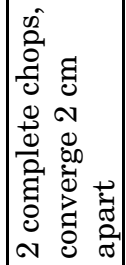 & 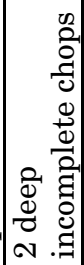 & & 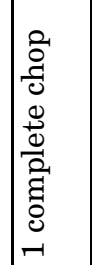 & 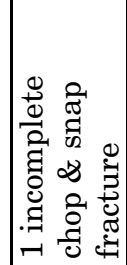 & & 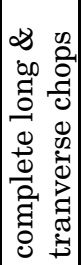 & & & & & & \\
\hline 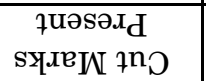 & 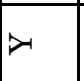 & $>$ & $\lambda$ & $\not>$ & & $\not>$ & 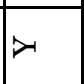 & & 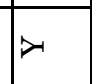 & $\not$ & & $>$ & & & & & & \\
\hline s̊ụ̣ungng & 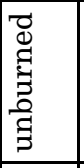 & 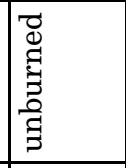 & 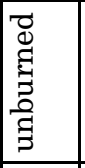 & 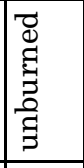 & 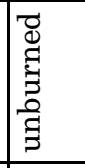 & 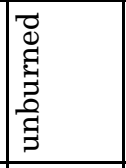 & 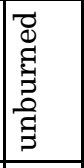 & 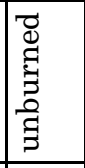 & 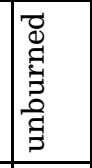 & 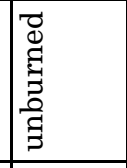 & 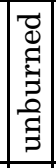 & 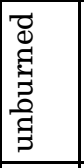 & \begin{tabular}{|l|} 
\\
0 \\
$\vdots$ \\
$\vdots$ \\
0 \\
$\vdots$ \\
$\vdots$ \\
\end{tabular} & 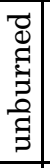 & 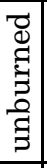 & 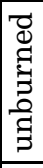 & 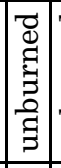 & 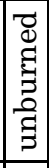 \\
\hline *ә.љ̊ечщәля & $\begin{array}{l}\tilde{\sigma} \\
\vec{z} \\
\text { ప్ } \\
\text { డี }\end{array}$ & 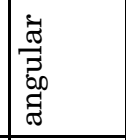 & $\begin{array}{l}\dot{\sigma} \\
\vec{z} \\
\overrightarrow{20} \\
\tilde{\sigma} \\
\end{array}$ & 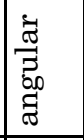 & 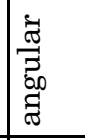 & 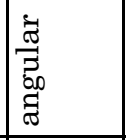 & 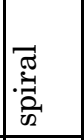 & 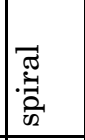 & 㺃 & कृ & 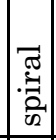 & 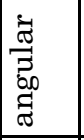 & 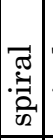 & 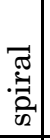 & \begin{tabular}{|l|}
$\vec{\sigma}$ \\
$\vec{z}$ \\
$\vec{z}_{0}$ \\
$\tilde{\sigma}$ \\
\end{tabular} & .ृ. & 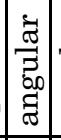 & $\begin{array}{l}\tilde{\sigma} \\
\vec{z} \\
\tilde{z} \\
\tilde{\sigma} \\
\tilde{\sigma}\end{array}$ \\
\hline әр!़ & & & & & & & & & & & 岕 & 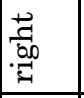 & 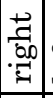 & 总 & 岂 & 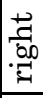 & 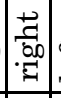 & 凷 \\
\hline uọฺx०d & 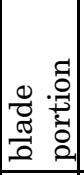 & 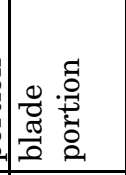 & 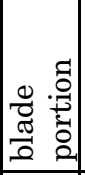 & 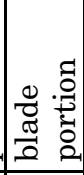 & . & 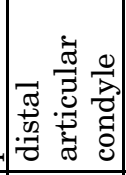 & 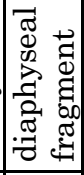 & 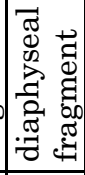 & 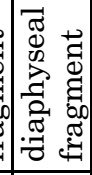 & 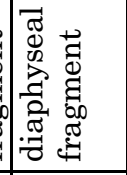 & 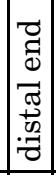 & 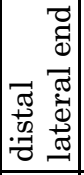 & 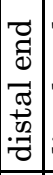 & 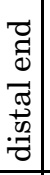 & 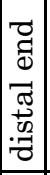 & 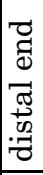 & 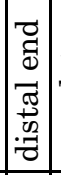 & 离 \\
\hline ұиәшә[Н & 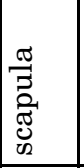 & 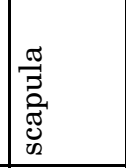 & 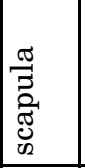 & 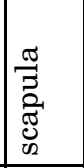 & 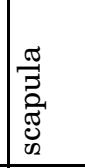 & 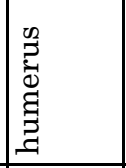 & \begin{tabular}{|l}
0 \\
0 \\
0 \\
00 \\
00 \\
0 \\
\end{tabular} & \begin{tabular}{|l}
0 \\
0 \\
0 \\
800 \\
0 \\
0 \\
\end{tabular} & $\begin{array}{l}0 \\
\tilde{0} \\
8 \\
00 \\
0 \\
0 \\
\end{array}$ & $\begin{array}{l}0 \\
0 \\
0 \\
8 \\
20 \\
0 \\
0 \\
\end{array}$ & 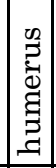 & 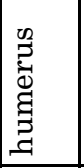 & 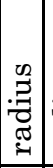 & 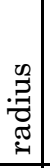 & 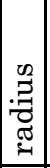 & 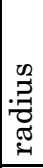 & 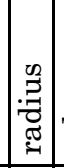 & 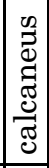 \\
\hline $\begin{array}{r}{ }^{\text {әuार }} \mathrm{N} \\
\text { uowumo }\end{array}$ & 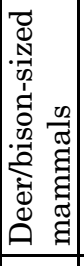 & 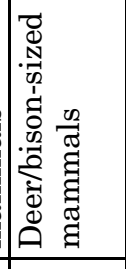 & 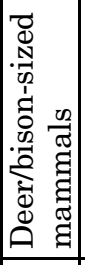 & 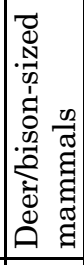 & 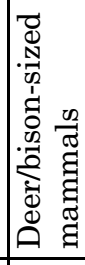 & 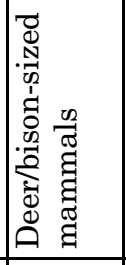 & 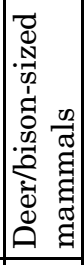 & 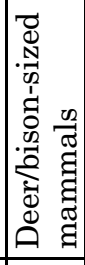 & 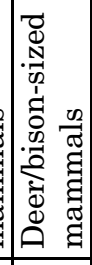 & 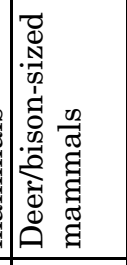 & 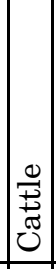 & 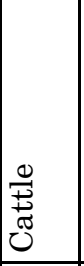 & 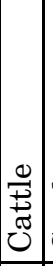 & 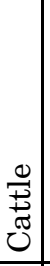 & 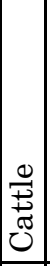 & 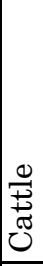 & 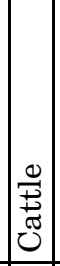 & 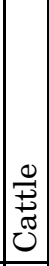 \\
\hline $\operatorname{uoxe}_{\mathrm{L}}$ & 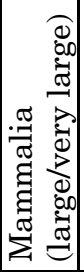 & 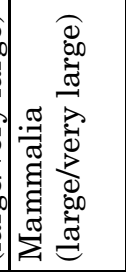 & 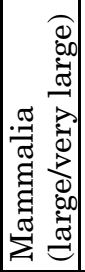 & 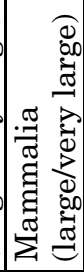 & 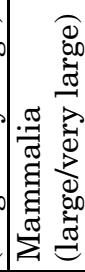 & 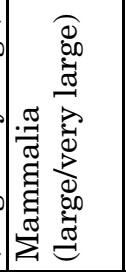 & 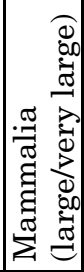 & 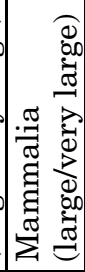 & 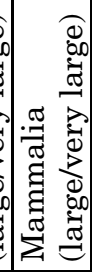 & 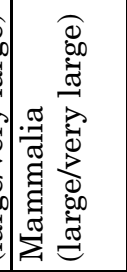 & $\mid \begin{array}{l}0 \\
0 \\
0 \\
0 \\
0 \\
0\end{array}$ & $\begin{array}{l}\dot{0} \\
0 \\
\dot{0} \\
0 \\
0\end{array}$ & $\left|\begin{array}{l}\dot{1} \\
0 \\
0 \\
0 \\
0 \\
0\end{array}\right|$ & $\mid \begin{array}{l}\dot{2} \\
0 \\
0 \\
0 \\
0 \\
0\end{array}$ & $\begin{array}{c}\dot{2} \\
0 \\
\dot{0} \\
0 \\
0\end{array}$ & \begin{tabular}{|c|}
$i_{1}$ \\
0 \\
$\infty$ \\
$\infty$ \\
$\infty$
\end{tabular} & $\left|\begin{array}{l}2 \\
0 \\
0 \\
0 \\
0 \\
0 \\
0\end{array}\right|$ & $\mid \begin{array}{l}i_{1} \\
0 \\
\infty \\
0 \\
0 \\
0\end{array}$ \\
\hline $\begin{array}{r}\text { uo!̣e!posst } \\
\text { әлпұеән }\end{array}$ & $\mathscr{F}$ & $\mathscr{F}$ & $\mathscr{F}$ & $\mathscr{F}$ & $\ddot{F}$ & $\mathscr{q}$ & $\mathscr{F}$ & $\mathscr{F}$ & $\mathscr{F}$ & $\mathscr{f}$ & $\mathscr{F}$ & $\mathscr{F}$ & 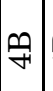 & $\mathscr{F}$ & 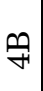 & $\vartheta$ & $\mathscr{F}$ & $\mathscr{F}$ \\
\hline 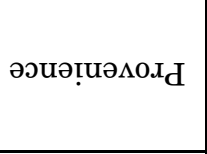 & 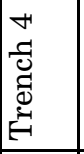 & 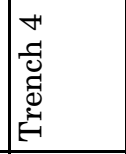 & 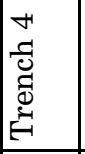 & 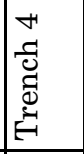 & 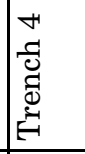 & 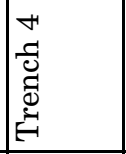 & 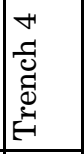 & 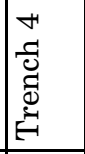 & 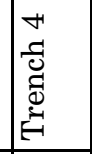 & 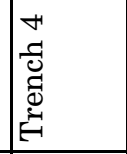 & 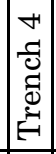 & 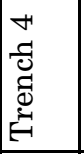 & 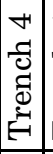 & 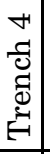 & 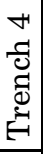 & 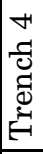 & 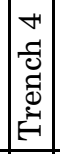 & 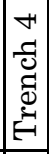 \\
\hline 'oN 70'T & 芯 & 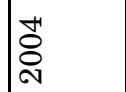 & 苍 & 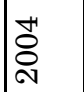 & 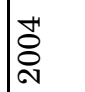 & ठั & | & 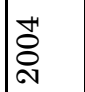 & 苍 & 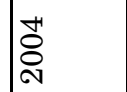 & 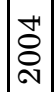 & 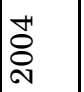 & 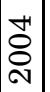 & 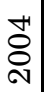 & 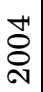 & 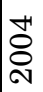 & 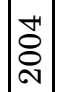 & 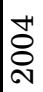 \\
\hline Кұ!ฺuenช & 4 & -1 & $\infty$ & -1 & H & -1 & -1 & 0 & - & - & -1 & -1 & -1 & -1 & -1 & -1 & -1 & - \\
\hline
\end{tabular}




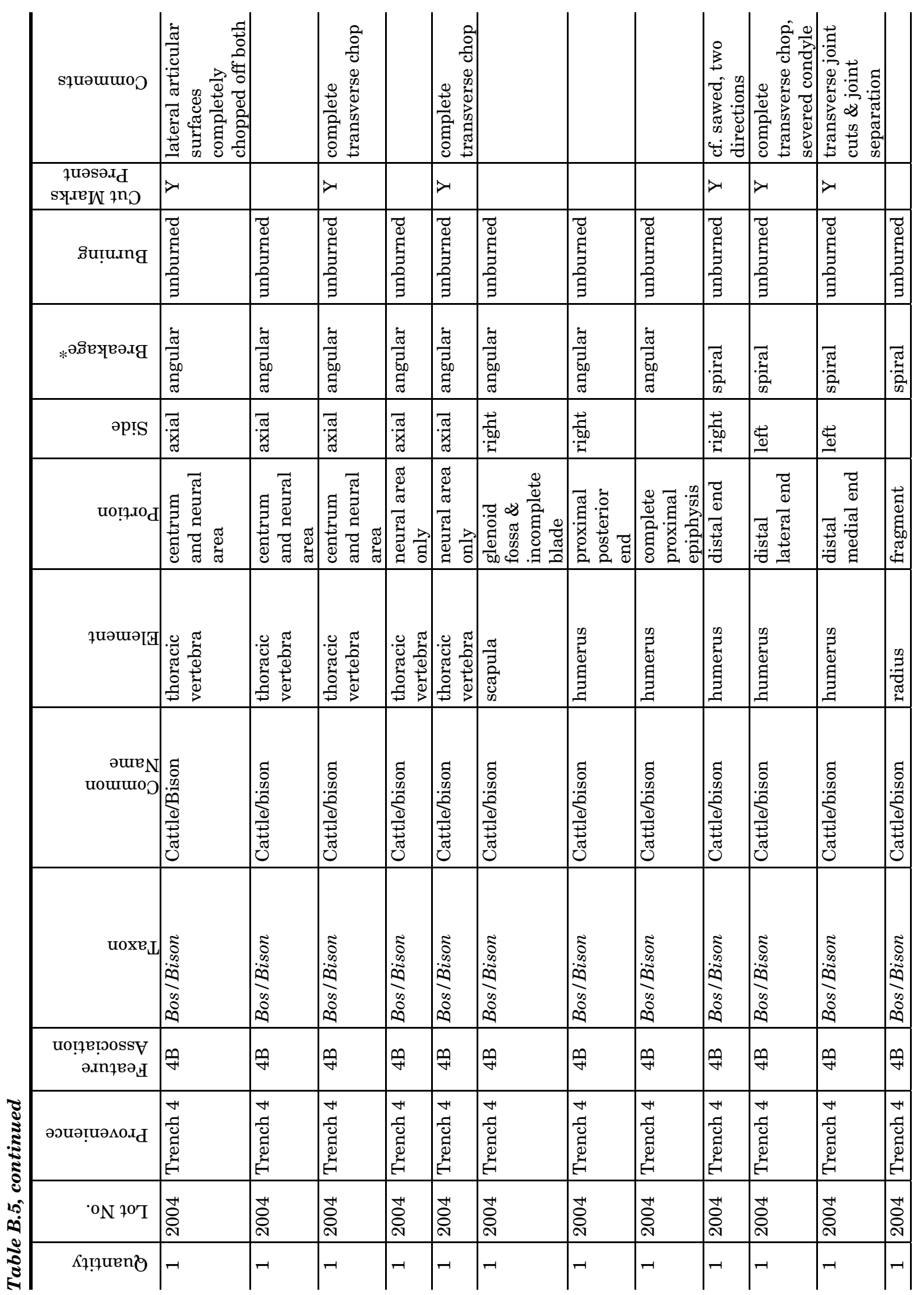




\begin{tabular}{|c|c|c|c|c|c|c|c|c|c|c|c|c|c|c|}
\hline sұuәшшо & & 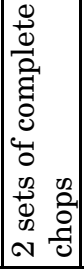 & & 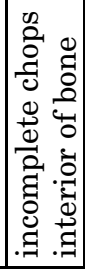 & 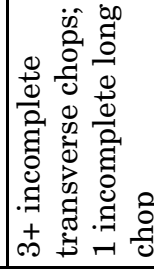 & & 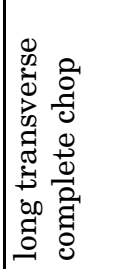 & & & 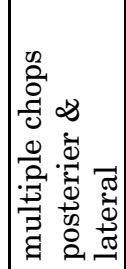 & & 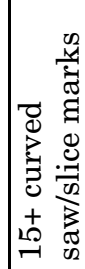 & 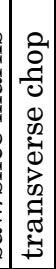 & \\
\hline 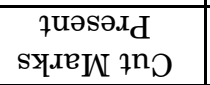 & & $>1$ & $\lambda$ & 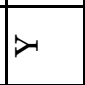 & 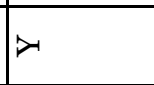 & & 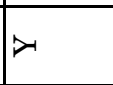 & & & $\not$ & & 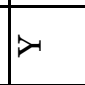 & 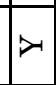 & \\
\hline .̊ụ̣u.nng & 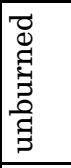 & 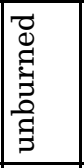 & 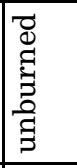 & 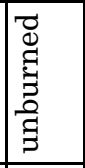 & 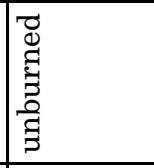 & 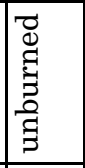 & 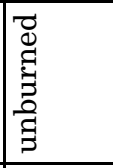 & 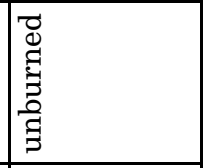 & 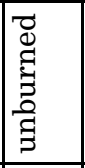 & 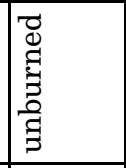 & 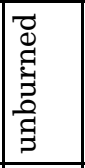 & 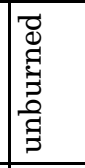 & 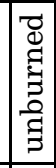 & 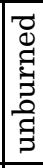 \\
\hline *ә.љ̊вчеәд & 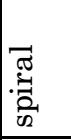 & 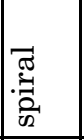 & 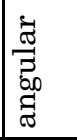 & 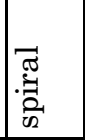 & 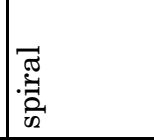 & 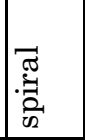 & 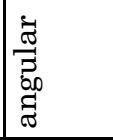 & 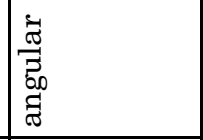 & 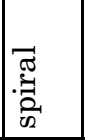 & 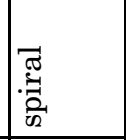 & $\begin{array}{l}\tilde{\sigma} \\
\overrightarrow{\tilde{z}} \\
\tilde{\sigma} \\
\tilde{\sigma} \\
\end{array}$ & 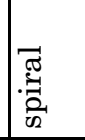 & $\begin{array}{l}\frac{\tilde{\sigma}}{\vec{\sigma}} \\
\overrightarrow{0} \\
\tilde{\sigma} \\
\end{array}$ & 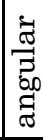 \\
\hline әр!़ & 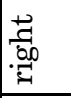 & 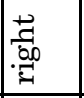 & 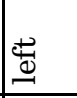 & & 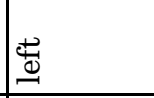 & 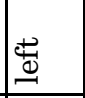 & 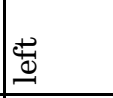 & 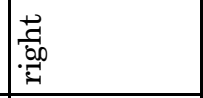 & & 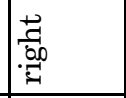 & & $\underset{\Theta}{\mathbb{Q}}$ & 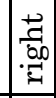 & \\
\hline uo!ฺxod & 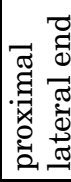 & 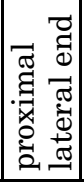 & 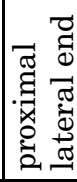 & 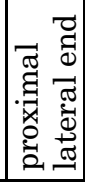 & 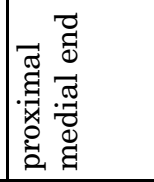 & 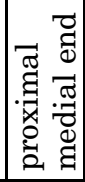 & 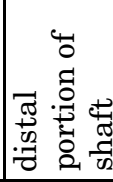 & 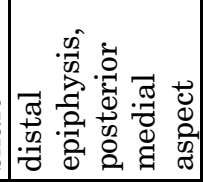 & 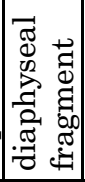 & 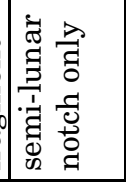 & 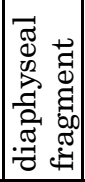 & 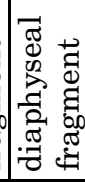 & 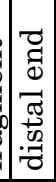 & 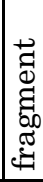 \\
\hline tom & 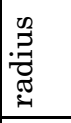 & 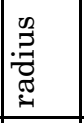 & 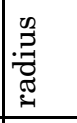 & 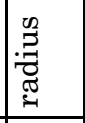 & 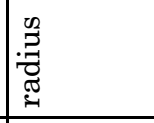 & 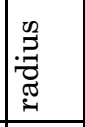 & 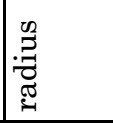 & 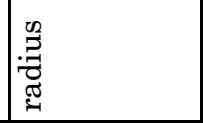 & 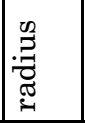 & $\frac{\varpi}{7}$ & $\frac{\dddot{\sigma}}{7}$ & $\frac{\pi}{\exists}$ & 胥 & 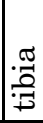 \\
\hline $\begin{array}{r}{ }^{\text {әuार }} \mathrm{N} \\
\text { uoumo }\end{array}$ & 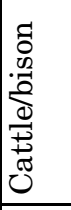 & 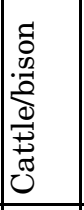 & 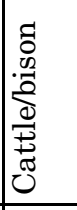 & 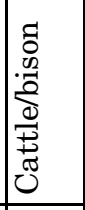 & 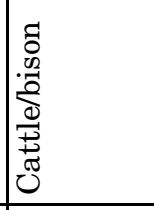 & 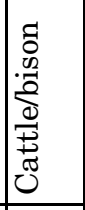 & 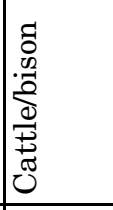 & 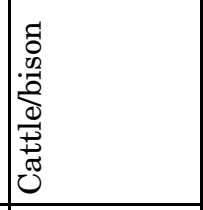 & 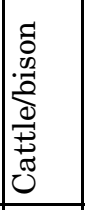 & 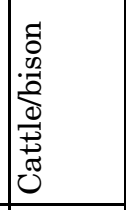 & 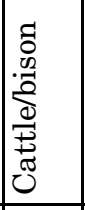 & 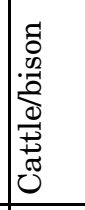 & 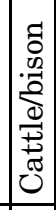 & 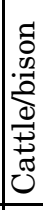 \\
\hline $\operatorname{uoxe}_{\mathrm{L}}$ & \begin{tabular}{|l}
5 \\
0 \\
0 \\
0 \\
0 \\
0 \\
0 \\
0
\end{tabular} & 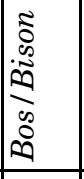 & 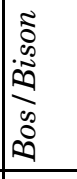 & \begin{tabular}{|l}
5 \\
$\vdots$ \\
0 \\
0 \\
0 \\
0 \\
0 \\
0 \\
0
\end{tabular} & 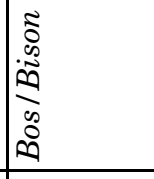 & $\begin{array}{l}5 \\
\vdots \\
0 \\
0 \\
0 \\
0 \\
0 \\
0 \\
0\end{array}$ & 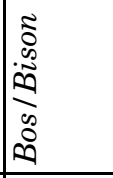 & 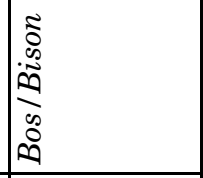 & 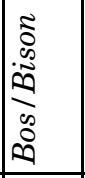 & 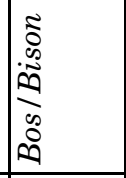 & 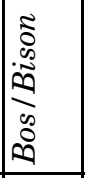 & 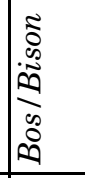 & $\mid \begin{array}{c}\tilde{0} \\
\tilde{\infty} \\
\tilde{0} \\
0 \\
0 \\
0 \\
0\end{array}$ & 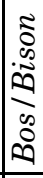 \\
\hline 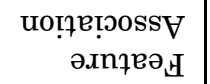 & F & $\approx$ & $\not$ & $\mathscr{F}$ & $\not{F}$ & $\not{F}$ & 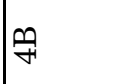 & $\not{F}$ & $\approx$ & $\not ै$ & $\approx$ & $\nexists$ & $\mathscr{F}$ & $\mathscr{F}$ \\
\hline 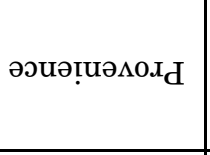 & 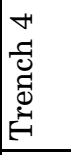 & 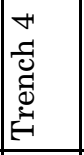 & 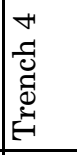 & 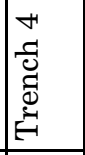 & 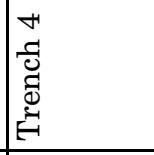 & 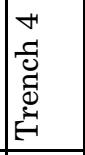 & 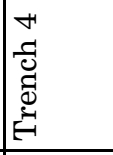 & 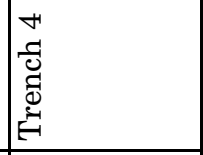 & 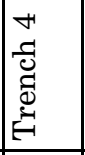 & 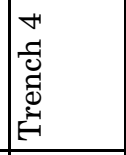 & 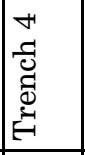 & 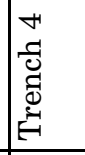 & & 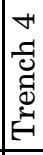 \\
\hline${ }^{\circ} \mathrm{N}+{ }^{\circ} \mathrm{T}$ & 容 & 容 & 苍 & 苍 & 苍 & 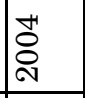 & 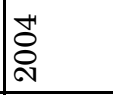 & 苍 & 苍 & 苍 & 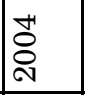 & 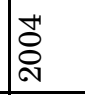 & $\begin{array}{l}+1 \\
\text { Oे } \\
\text { N }\end{array}$ & 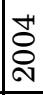 \\
\hline 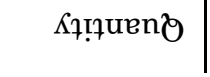 & - & -1 & -1 & -1 & -1 & -1 & -1 & -1 & -1 & -1 & & -1 & -1 & -1 \\
\hline
\end{tabular}




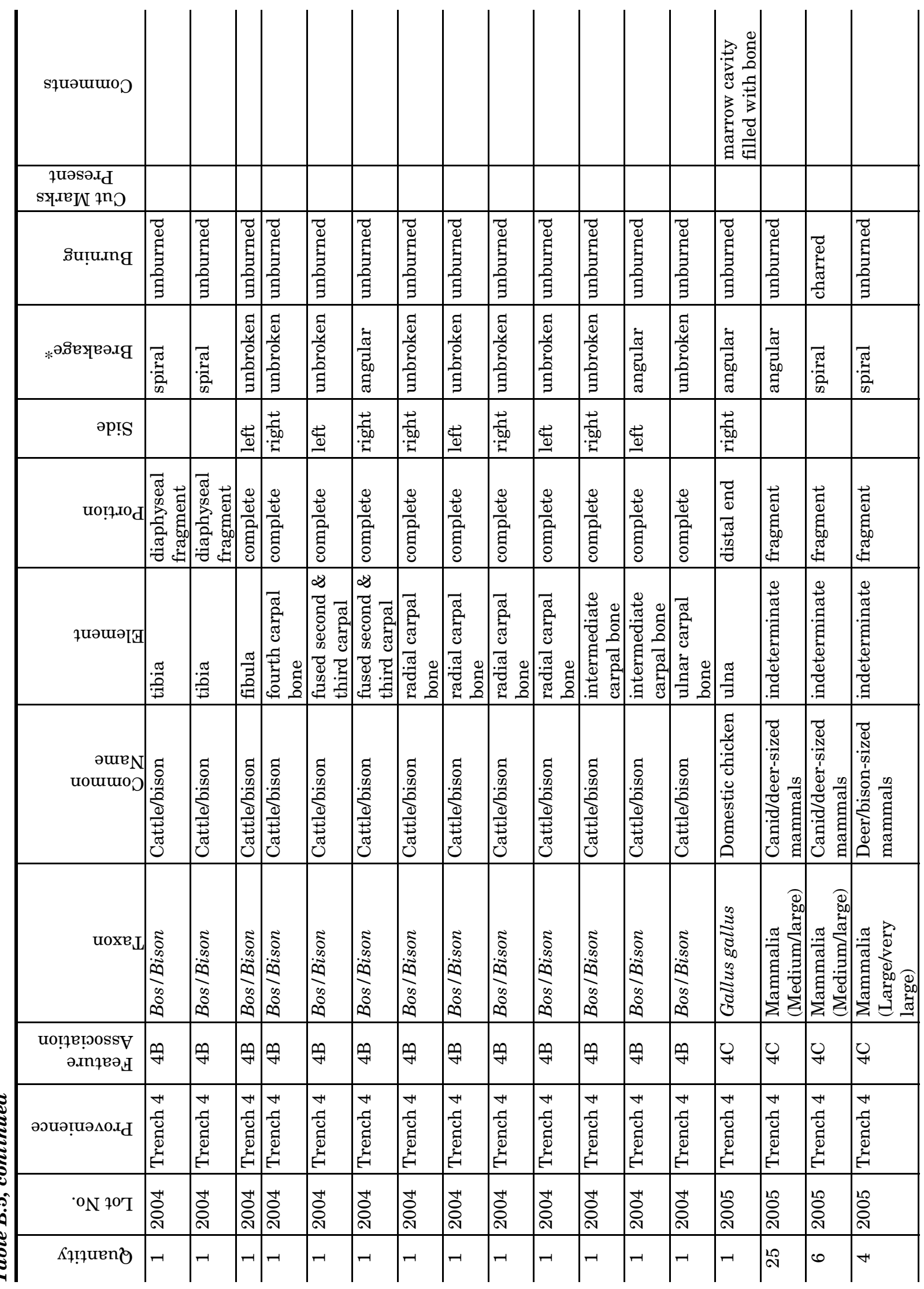




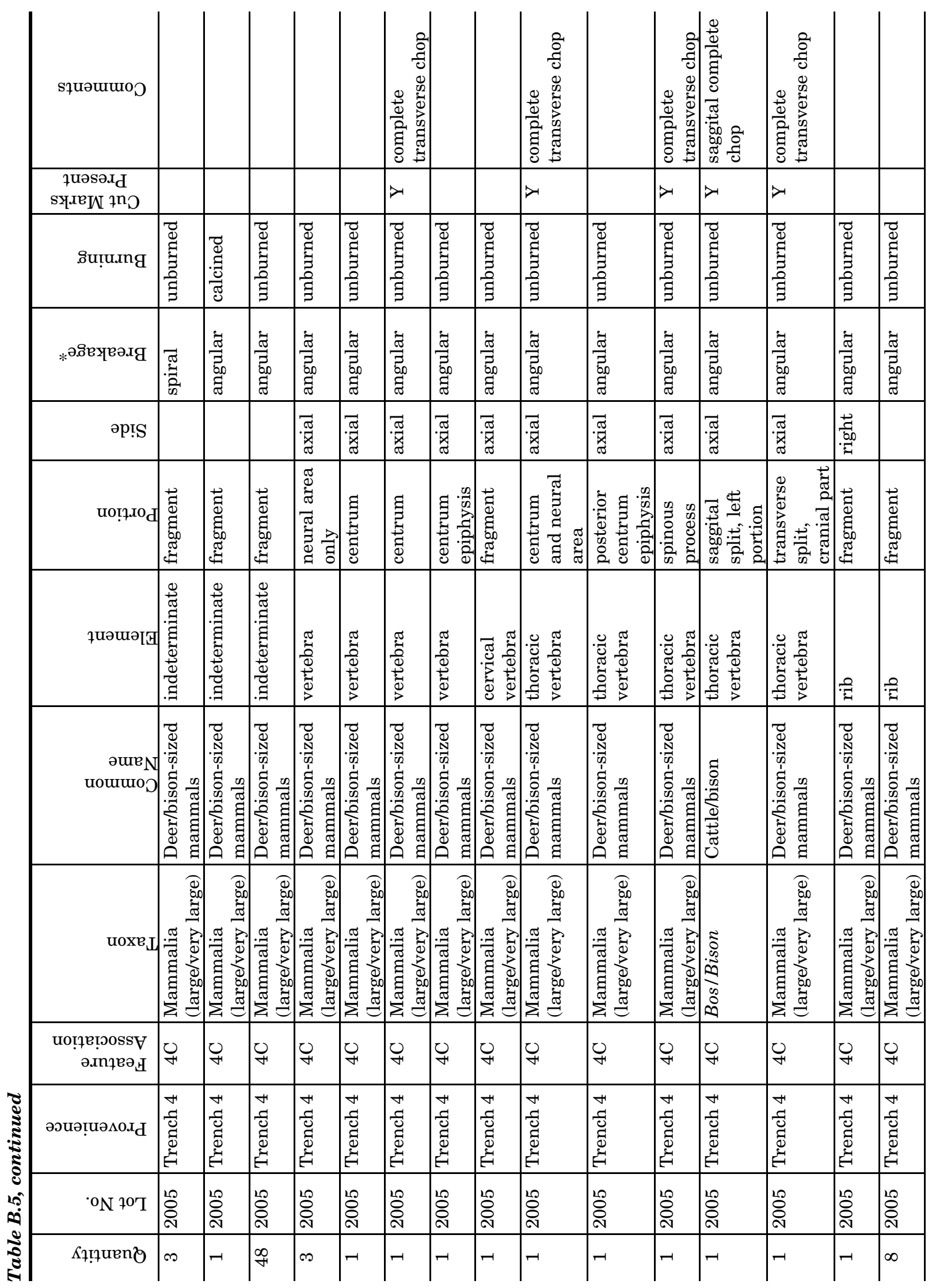




\begin{tabular}{|c|c|c|c|c|c|c|c|c|c|c|c|c|c|c|c|c|}
\hline squәшuо & & & & & & & & & 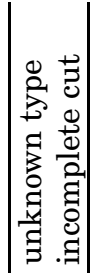 & & 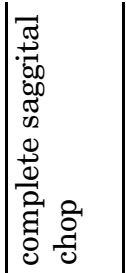 & & 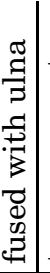 & 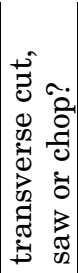 & & \\
\hline 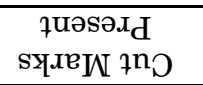 & & & & & & & & & 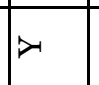 & & $>$ & & & $>$ & & \\
\hline .̊ిụ̣uxng & 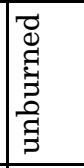 & 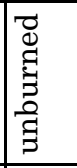 & 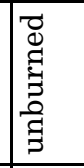 & 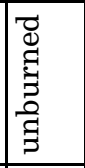 & 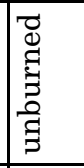 & 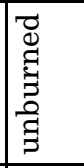 & 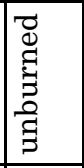 & 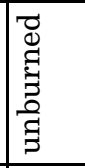 & 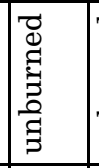 & 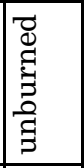 & 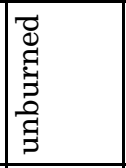 & 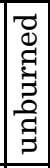 & 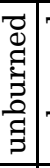 & 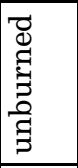 & 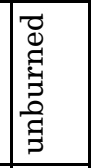 & 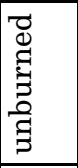 \\
\hline *әљвеувәля & 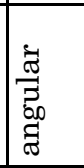 & \begin{tabular}{|l}
$\tilde{\tilde{\sigma}}$ \\
$\overrightarrow{\tilde{z}}$ \\
$\tilde{\sigma}$ \\
$\tilde{\sigma}$ \\
\end{tabular} & 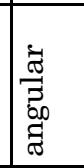 & 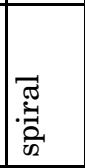 & 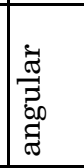 & 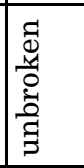 & \begin{tabular}{|l}
$\tilde{\tilde{\sigma}}$ \\
$\overrightarrow{\tilde{z}}$ \\
$\tilde{\sigma}$ \\
$\tilde{\sigma}$ \\
\end{tabular} & 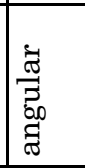 & 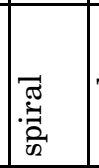 & \begin{tabular}{|l}
$\tilde{\sigma}$ \\
$\tilde{\sigma}$ \\
$\overrightarrow{5}$ \\
$\tilde{\sigma}$ \\
$\tilde{\sigma}$ \\
\end{tabular} & 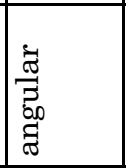 & 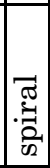 & 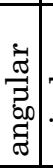 & 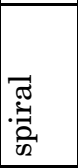 & 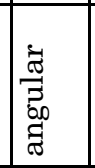 & 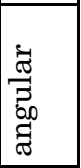 \\
\hline әр!S & 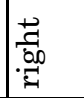 & & & & & & & & & 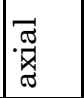 & 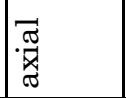 & 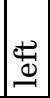 & $\underset{\Xi}{ \pm}$ & 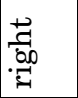 & 岕 & 苞 \\
\hline uo!̣xxod & 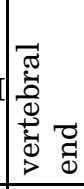 & 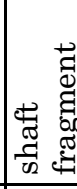 & 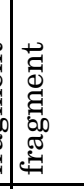 & 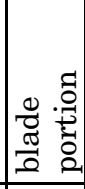 & 造 & 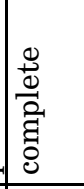 & 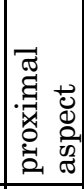 & 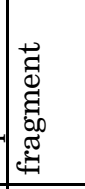 & 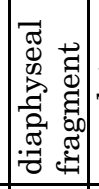 & 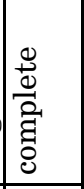 & 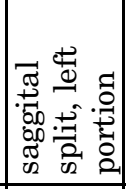 & 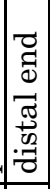 & 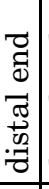 & 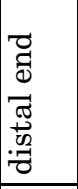 & 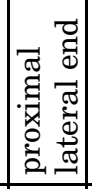 & 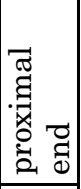 \\
\hline ұиәшәнН & $\frac{0}{\pi}$ & 을 & 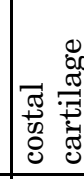 & 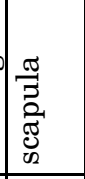 & 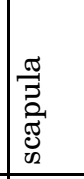 & 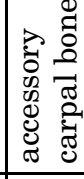 & 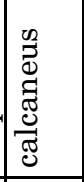 & 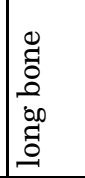 & $\begin{array}{l}0 \\
0 \\
00 \\
00 \\
0 \\
0\end{array}$ & 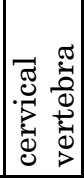 & 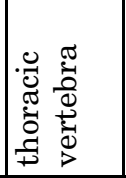 & 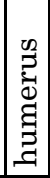 & 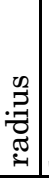 & 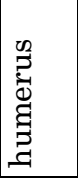 & 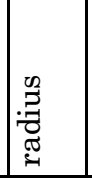 & $\frac{\pi}{3}$ \\
\hline $\begin{array}{r}{ }^{\text {әше }} \mathrm{N} \\
\text { uowumoग }\end{array}$ & 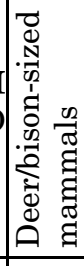 & 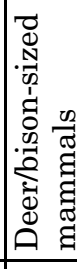 & 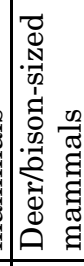 & 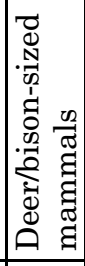 & 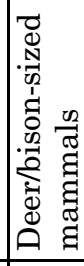 & 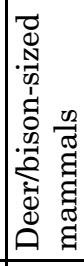 & 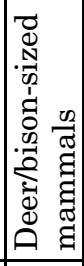 & 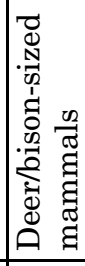 & 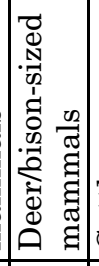 & 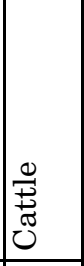 & 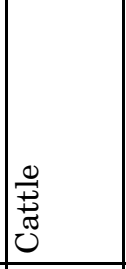 & 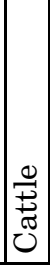 & 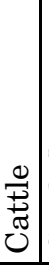 & 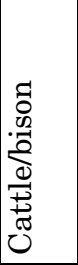 & 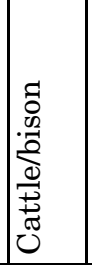 & 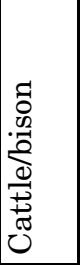 \\
\hline $\operatorname{uoxe}_{\mathrm{J}}$ & 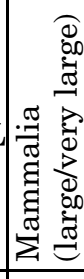 & 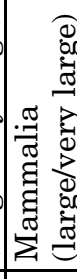 & 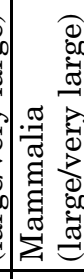 & 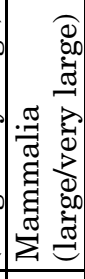 & 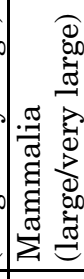 & 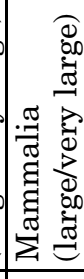 & 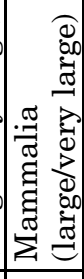 & 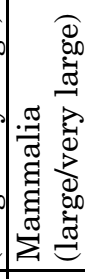 & 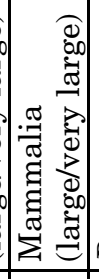 & $\begin{array}{l}1 \\
\\
\dot{2} \\
02 \\
0 \\
\infty \\
\infty \\
\end{array}$ & 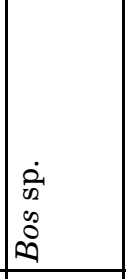 & $\begin{array}{l}\dot{2} \\
0 \\
0 \\
0 \\
0 \\
\infty\end{array}$ & $\begin{array}{c}0 \\
2 \\
0 \\
0 \\
0 \\
0\end{array}$ & 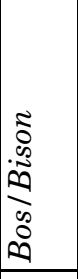 & 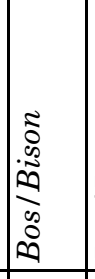 & 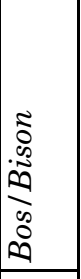 \\
\hline 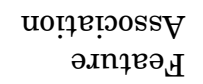 & OH & O্ & O & Or & O্ & O & O্ & O & O্ & O্ & U & $\underset{\forall}{0}$ & $\underset{\forall}{0}$ & Oיa & O & Or \\
\hline 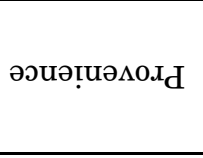 & 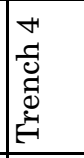 & 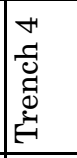 & 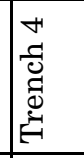 & 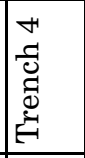 & 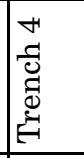 & 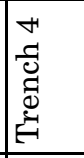 & 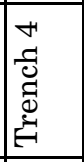 & 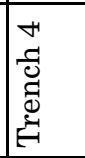 & 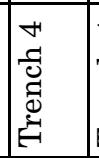 & 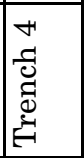 & 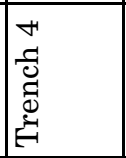 & 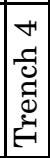 & 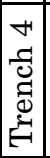 & 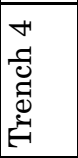 & 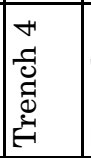 & 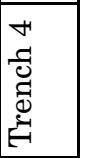 \\
\hline ON 70T & $\begin{array}{l}10 \\
0 \\
0 \\
0\end{array}$ & 농 & Li⿱ & 농 & 늉 & $\begin{array}{l}20 \\
\text { Oิ } \\
\text { ลे }\end{array}$ & 농 & 뇽 & 뇽 & Li⿱ & 늉 & 낭 & 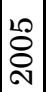 & i & 象 & 禺 \\
\hline Кұฺฺนenฮู & -1 & 0 & 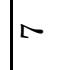 & -1 & o & -1 & -1 & -1 & -1 & -1 & -1 & -1 & -1 & -1 & - & -1 \\
\hline
\end{tabular}




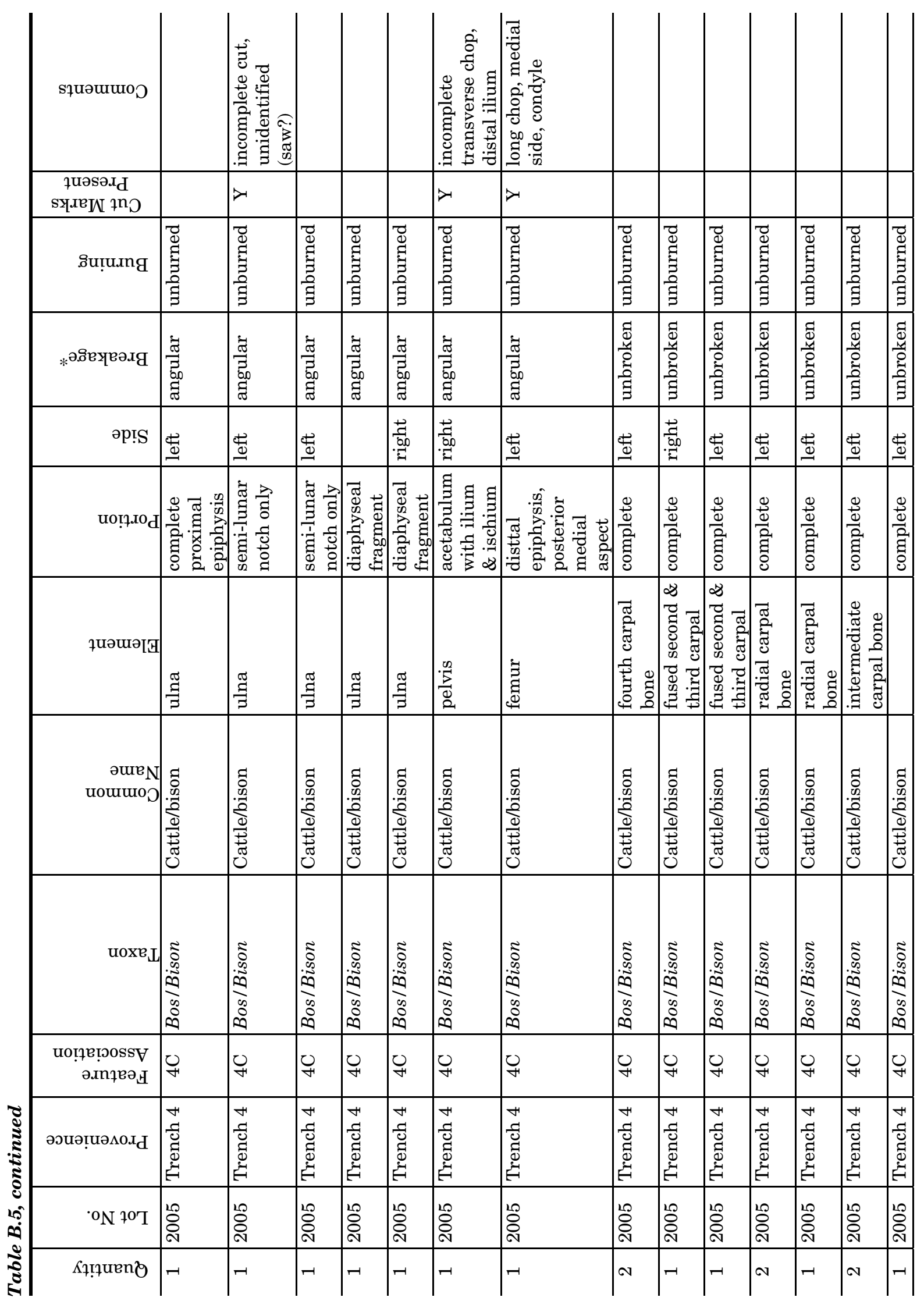




\begin{tabular}{|c|c|c|c|c|c|c|c|c|c|c|c|c|c|c|c|c|}
\hline sұuәшшо & & & & & & & 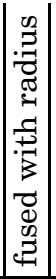 & & 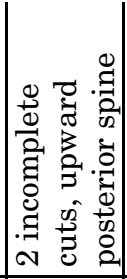 & & 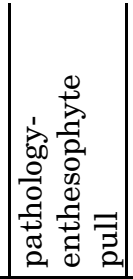 & & \begin{tabular}{|l}
0 \\
0 \\
0 \\
0 \\
0 \\
0 \\
0 \\
0 \\
0 \\
0 \\
0
\end{tabular} & 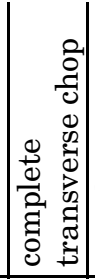 & 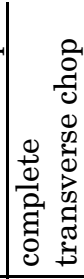 & 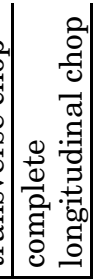 \\
\hline 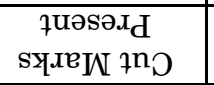 & & & & & & & & & $\lambda$ & & & & 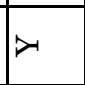 & 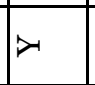 & 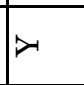 & $\gg$ \\
\hline .suṭung & 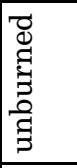 & 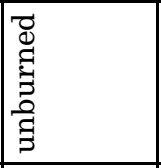 & 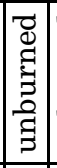 & 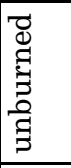 & 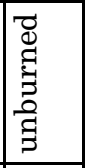 & 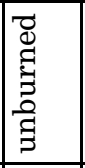 & 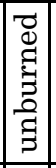 & 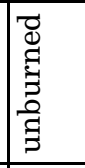 & 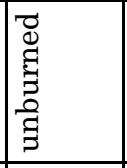 & 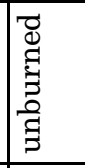 & 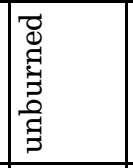 & 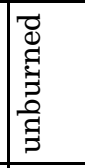 & 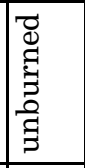 & 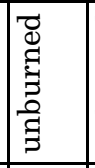 & 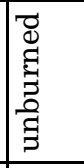 & 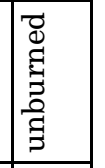 \\
\hline *ә.љిеуеәля & 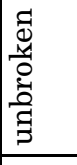 & 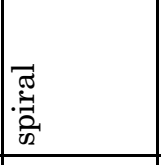 & 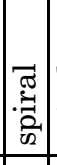 & 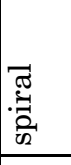 & 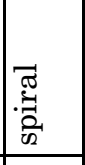 & 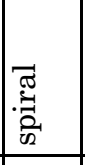 & 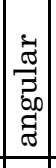 & \begin{tabular}{|l}
$\tilde{\sigma}$ \\
$\frac{\tilde{7}}{5}$ \\
$\vdots 0$ \\
$\tilde{\sigma}$ \\
\end{tabular} & 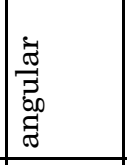 & 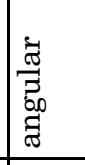 & 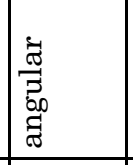 & 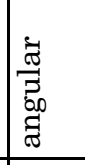 & 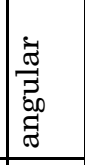 & 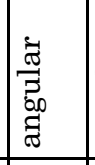 & 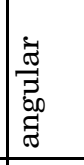 & 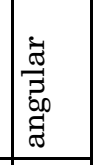 \\
\hline әр!़ & 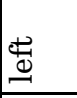 & & & & 岕 & & 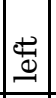 & & 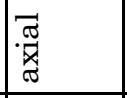 & 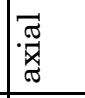 & & & & & 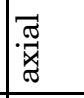 & 丞 \\
\hline uo!̣.10d & 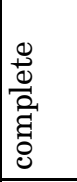 & 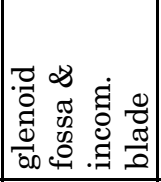 & 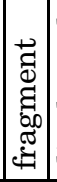 & 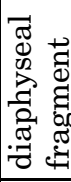 & 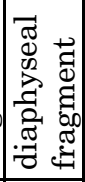 & 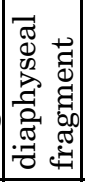 & 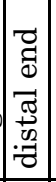 & 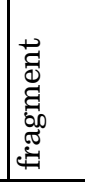 & 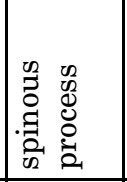 & 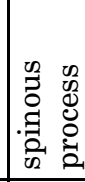 & 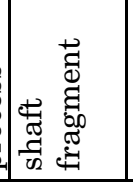 & 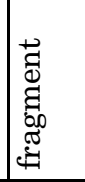 & 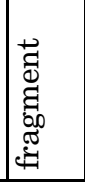 & 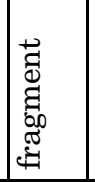 & 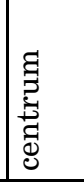 & 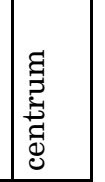 \\
\hline ұиәшәเ⿴囗十 & 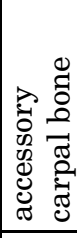 & 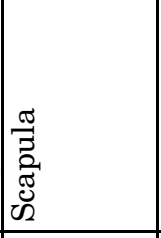 & 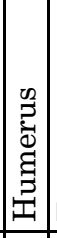 & 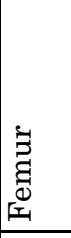 & 营 & 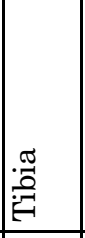 & 官 & 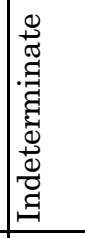 & 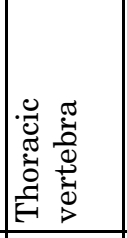 & 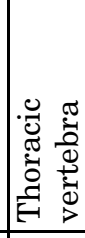 & 울 & 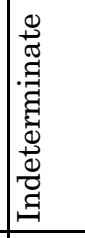 & 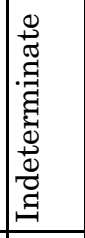 & 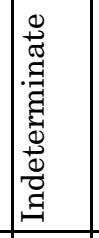 & 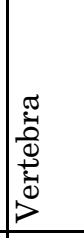 & 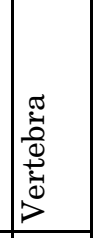 \\
\hline $\begin{array}{r}\text { әше० } N \\
\text { uowuro }\end{array}$ & 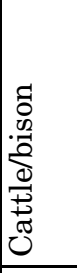 & 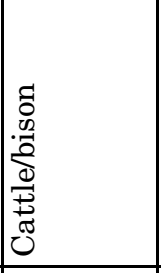 & 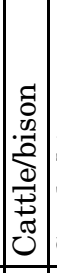 & 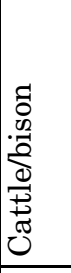 & 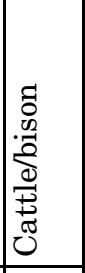 & 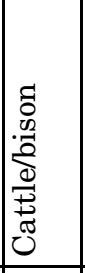 & 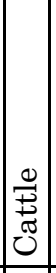 & 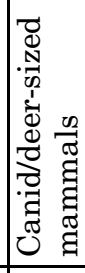 & 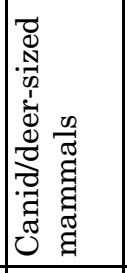 & 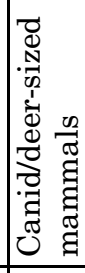 & 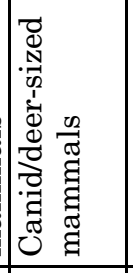 & 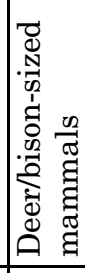 & 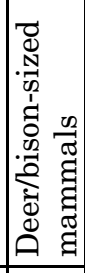 & 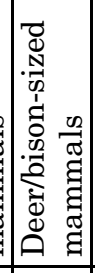 & 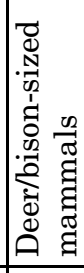 & 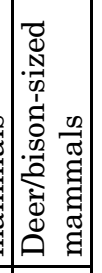 \\
\hline $\operatorname{uoxe}_{\mathrm{L}}$ & 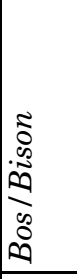 & 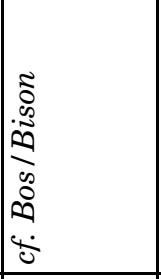 & 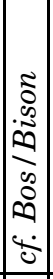 & $\begin{array}{l}5 \\
0 \\
0 \\
0 \\
0 \\
0 \\
0 \\
0 \\
0.0 \\
0\end{array}$ & 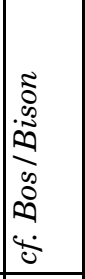 & 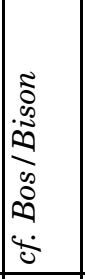 & \begin{tabular}{|l|} 
\\
\\
$\dot{2}$ \\
0 \\
0 \\
0 \\
0 \\
0 \\
\end{tabular} & 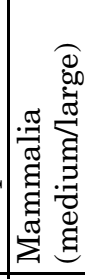 & 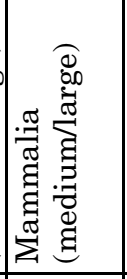 & 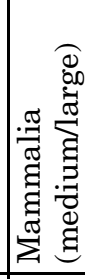 & 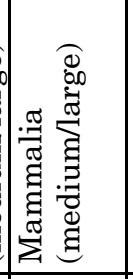 & 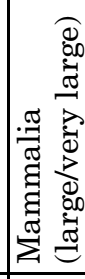 & 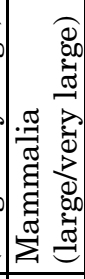 & 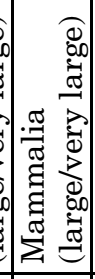 & 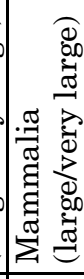 & 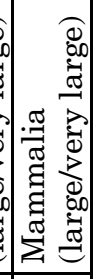 \\
\hline 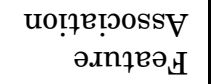 & 华 & i্ & O্+ & O্+ & O্ & Z & | & F & F & F & F & F & F & F & F & F \\
\hline 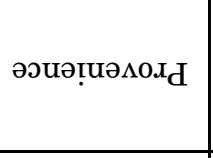 & 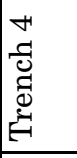 & 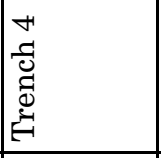 & 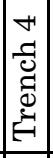 & 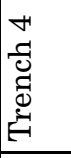 & 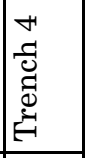 & 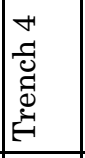 & 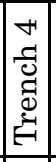 & 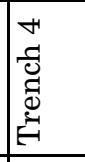 & 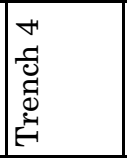 & 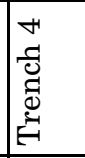 & 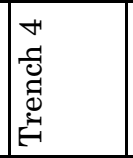 & 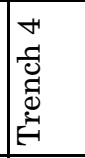 & 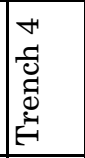 & 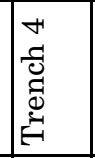 & 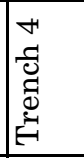 & 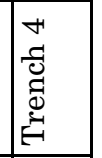 \\
\hline${ }^{\circ} \mathrm{N} 7^{\circ} \mathrm{T}$ & 용 & 농 & 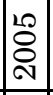 & 용 & ㄴo & 농 & 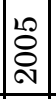 & స్̊ & ڤิి & ڤ્ڤ & స్̊ & ڤ્ڤ & 令 & ڤ્̊ & సิ & 周 \\
\hline Кұฺฺนuenฮ & -1 & -1 & $\infty$ & - & -1 & -1 & -1 & $\stackrel{10}{\sim}$ & - & -1 & -1 & $\stackrel{\infty}{\rightarrow}$ & $\infty$ & a & -1 & -1 \\
\hline
\end{tabular}




\begin{tabular}{|c|c|c|c|c|c|c|c|c|c|c|c|c|c|c|}
\hline squәшuо & 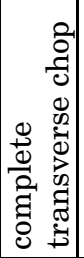 & & 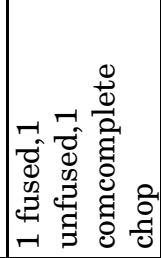 & & 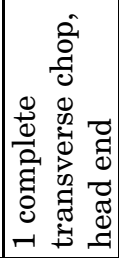 & 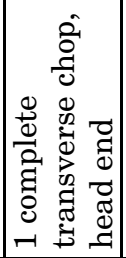 & & & 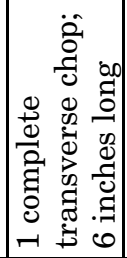 & & 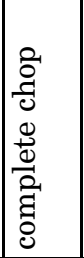 & & & \\
\hline 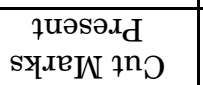 & $\succ$ & & 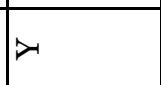 & & $\lambda$ & 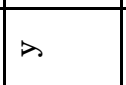 & & & $\lambda$ & & $\lambda$ & & & \\
\hline soụ̣u.nng & 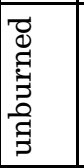 & 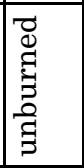 & 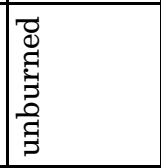 & 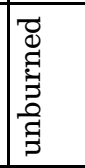 & 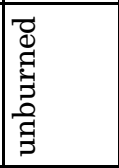 & 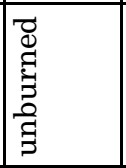 & 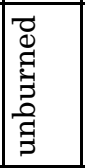 & 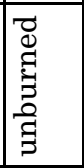 & 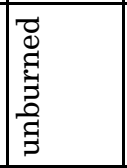 & 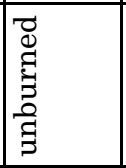 & 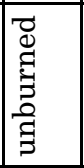 & 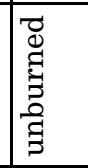 & 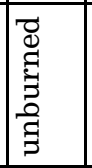 & 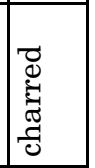 \\
\hline *ә.љ̈ечеәля & 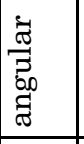 & 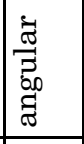 & \begin{tabular}{|l}
$\tilde{\sigma}_{0}$ \\
$\vec{z}_{0}$ \\
$\tilde{\sigma}$ \\
డี
\end{tabular} & 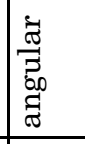 & $\begin{array}{l}\tilde{\sigma} \\
\vec{z} \\
\tilde{z}_{0} \\
\tilde{\sigma} \\
\end{array}$ & $\begin{array}{l}\tilde{\sigma} \\
\vec{z} \\
\tilde{z}_{0} \\
\tilde{\sigma} \\
\end{array}$ & 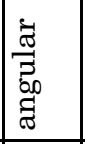 & 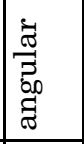 & 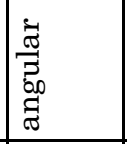 & 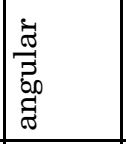 & $\begin{array}{l}\tilde{\sigma} \\
\overrightarrow{\tilde{z}_{0}} \\
\tilde{\tau} \\
\tilde{\sigma}\end{array}$ & 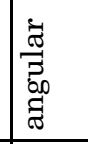 & 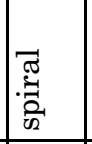 & 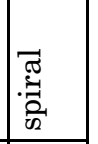 \\
\hline әр!़ & 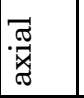 & 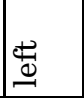 & 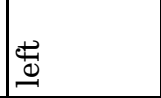 & 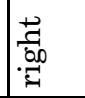 & 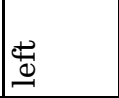 & $\underset{\Theta}{\stackrel{0}{\rightleftarrows}}$ & & 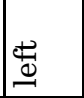 & 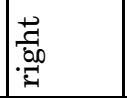 & & & & & \\
\hline uo!q. & 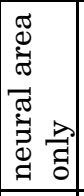 & 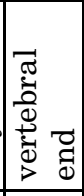 & 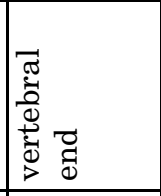 & 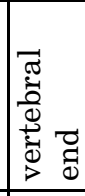 & 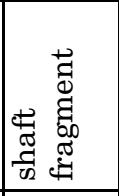 & 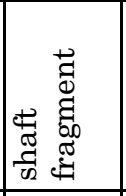 & 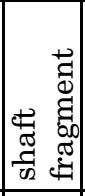 & 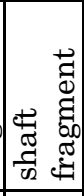 & 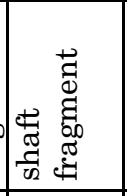 & 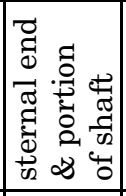 & 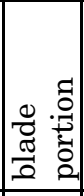 & 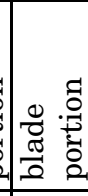 & 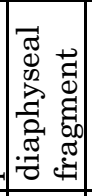 & 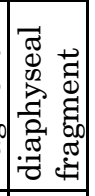 \\
\hline ұиәшәस & 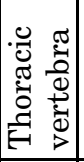 & 룰 & 层 & 色 & 色 & 色 & 룰 & 色 & 色 & 色 & 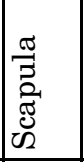 & 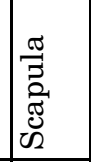 & 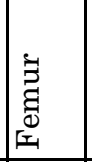 & $\begin{array}{l}0 \\
\vdots \\
0 \\
000 \\
00 \\
0 \\
\end{array}$ \\
\hline $\begin{array}{r}{ }^{\text {әше }} \mathrm{N} \\
\text { uoumuo }\end{array}$ & 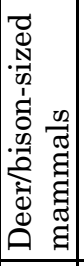 & 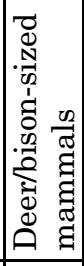 & 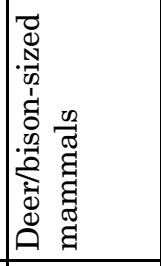 & 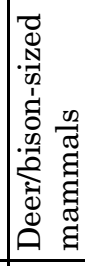 & 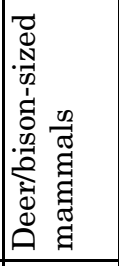 & 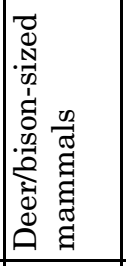 & 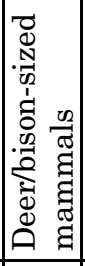 & 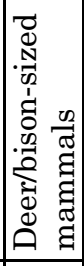 & 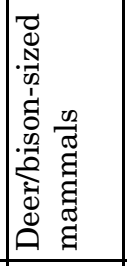 & 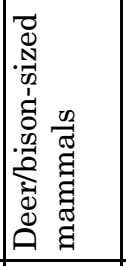 & 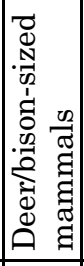 & 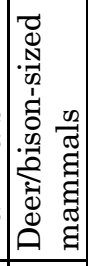 & 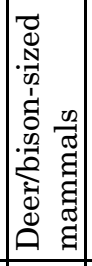 & 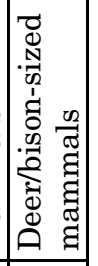 \\
\hline $\operatorname{uoxe}_{\mathrm{L}}$ & 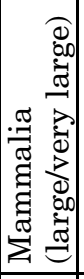 & 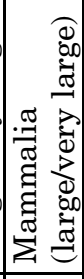 & 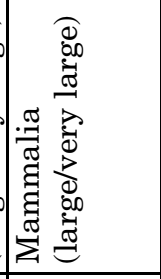 & 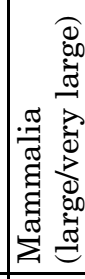 & 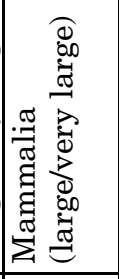 & 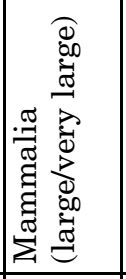 & 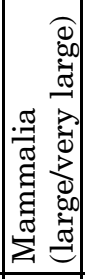 & 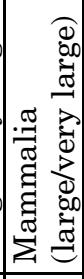 & 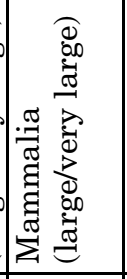 & 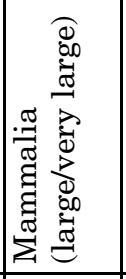 & 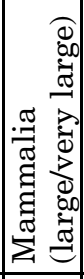 & 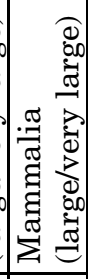 & 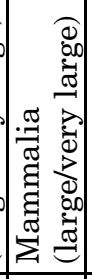 & 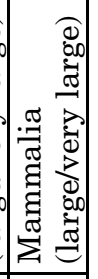 \\
\hline $\begin{array}{r}\text { uo!̣ழழ̣ossy } \\
\text { әипұеәә }\end{array}$ & F & F & F & F & F & F & F & F & F & F & F & F & F & F \\
\hline 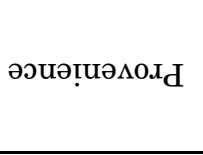 & 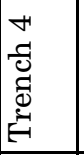 & 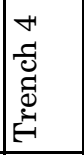 & 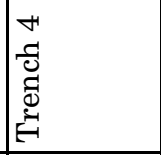 & 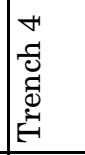 & 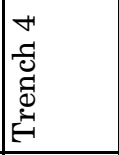 & 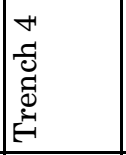 & 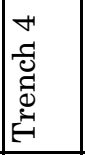 & 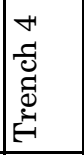 & 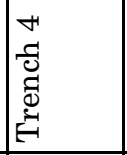 & 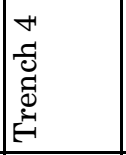 & 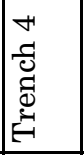 & 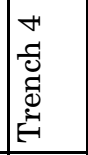 & 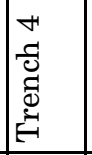 & 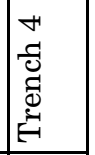 \\
\hline${ }^{\circ} \mathrm{N}{ }^{70} \mathrm{~T}$ & ڤิ) & กิ & ํㅗㅇ & 옹 & 合 & ลิ & 於 & ํㅗㅇ & ํํำ & ลิ & ลิ & 옹 & 於 & 周 \\
\hline Кұฺฺuenð & -1 & $\infty$ & -1 & $\infty$ & -1 & -1 & ขี & 0 & -1 & a & -1 & $\infty$ & -1 & $\neg$ \\
\hline
\end{tabular}




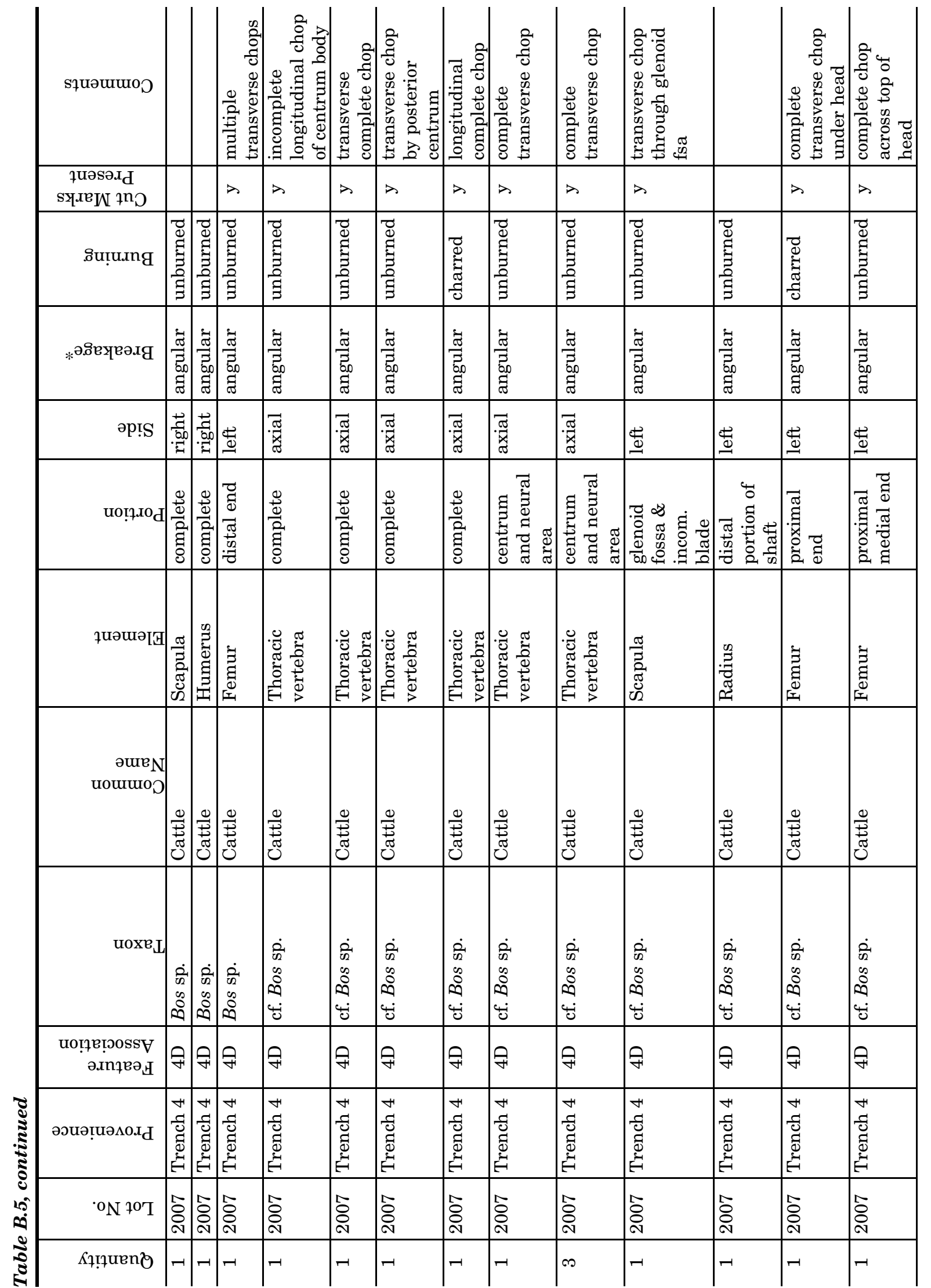




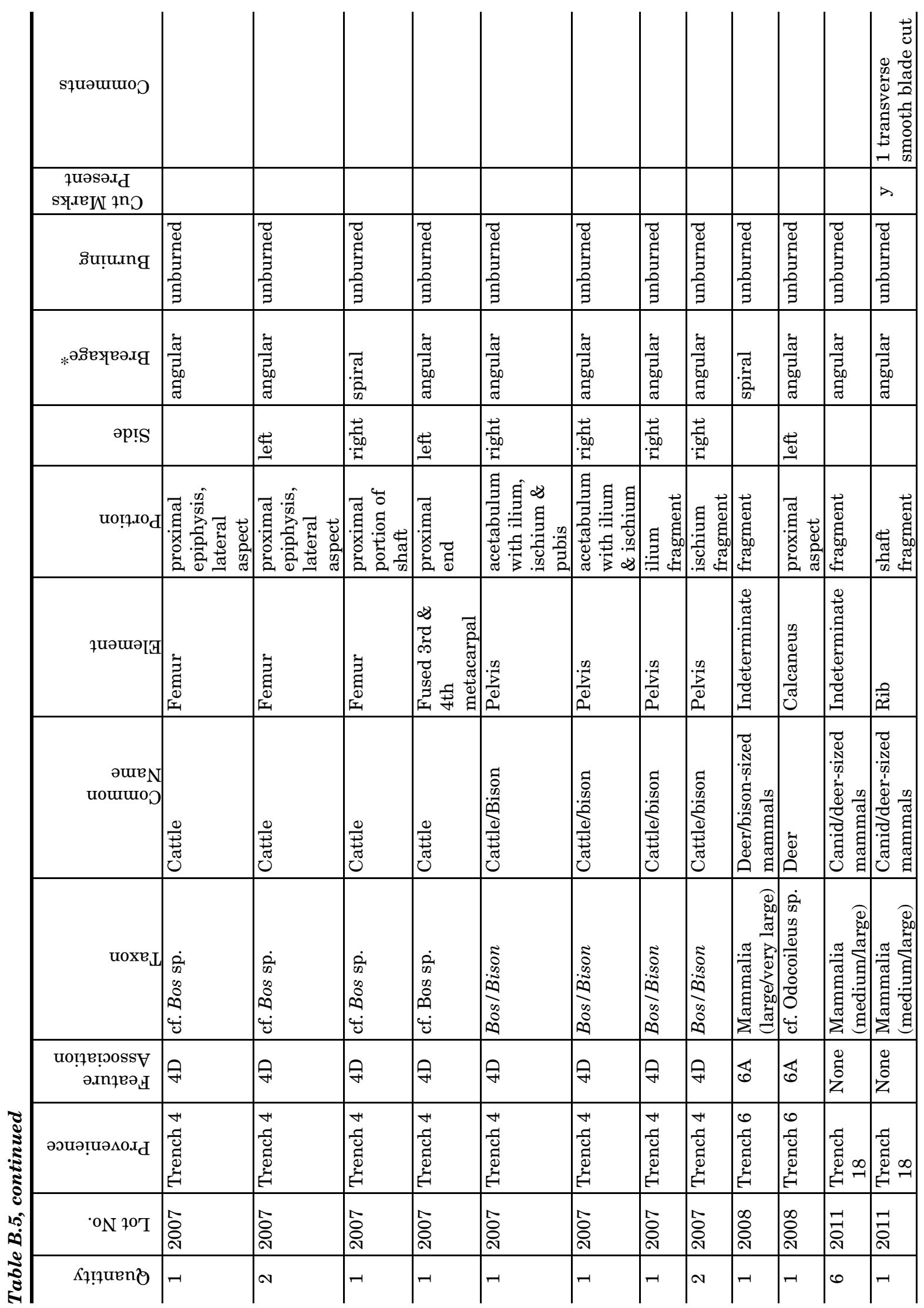




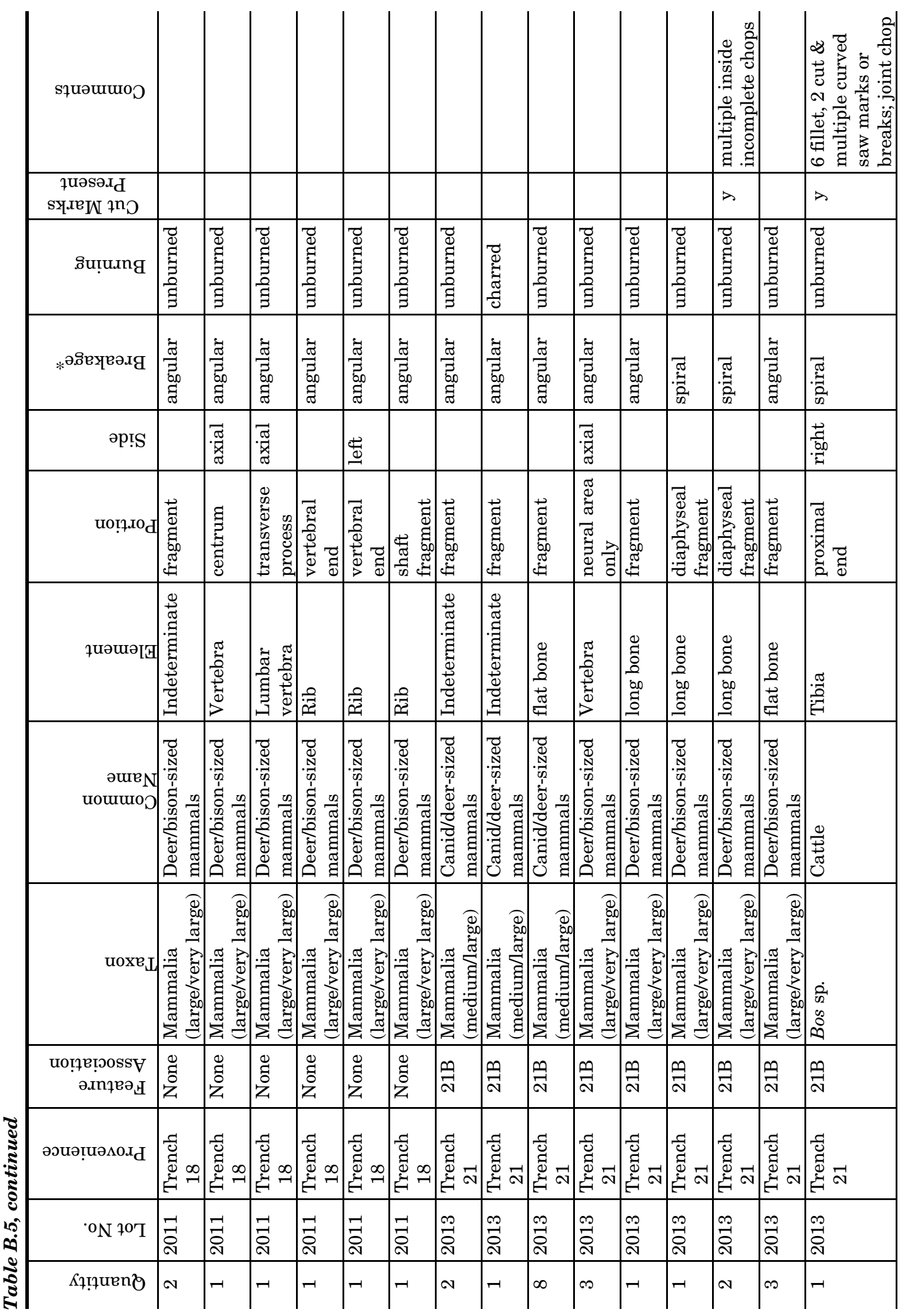




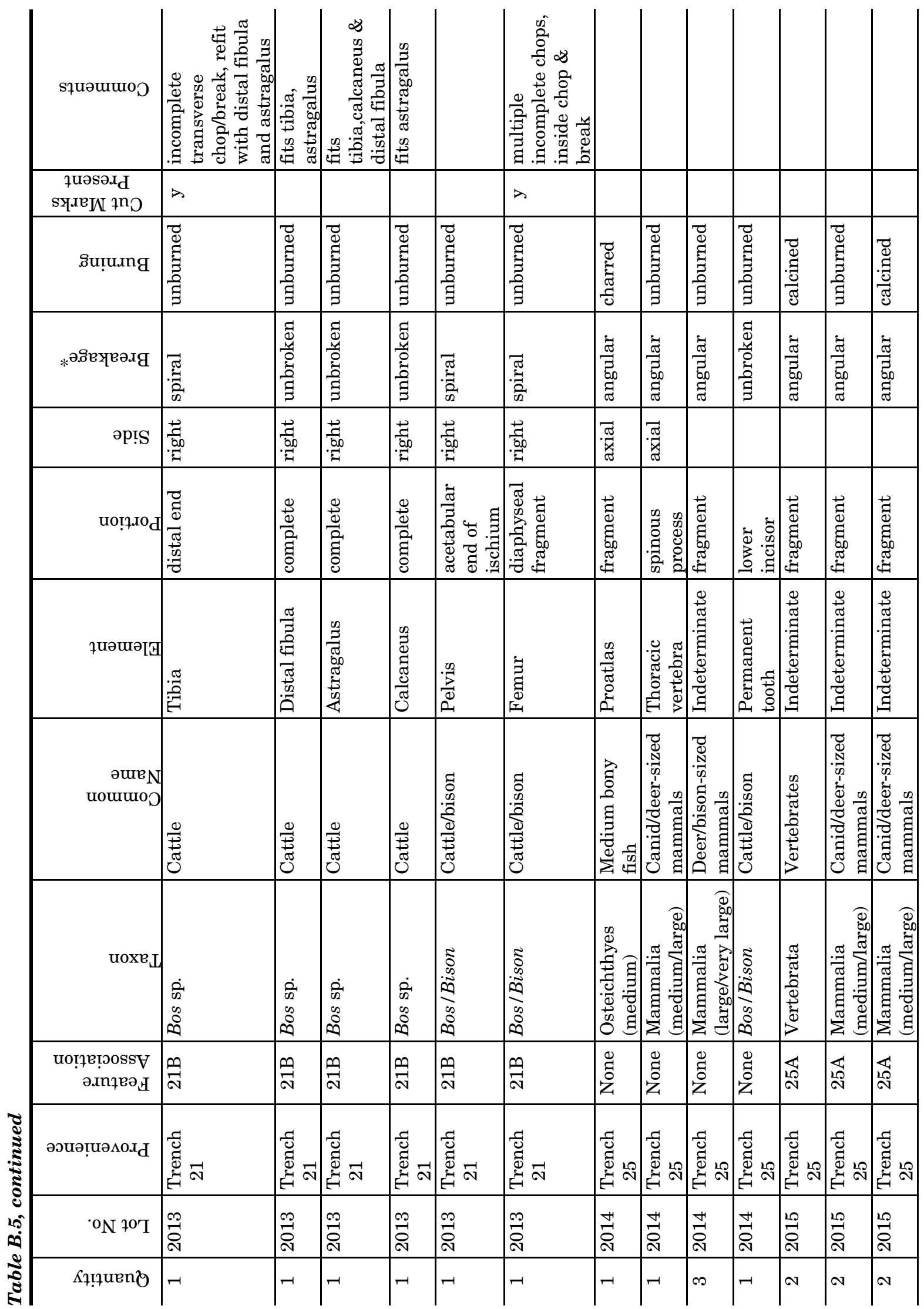




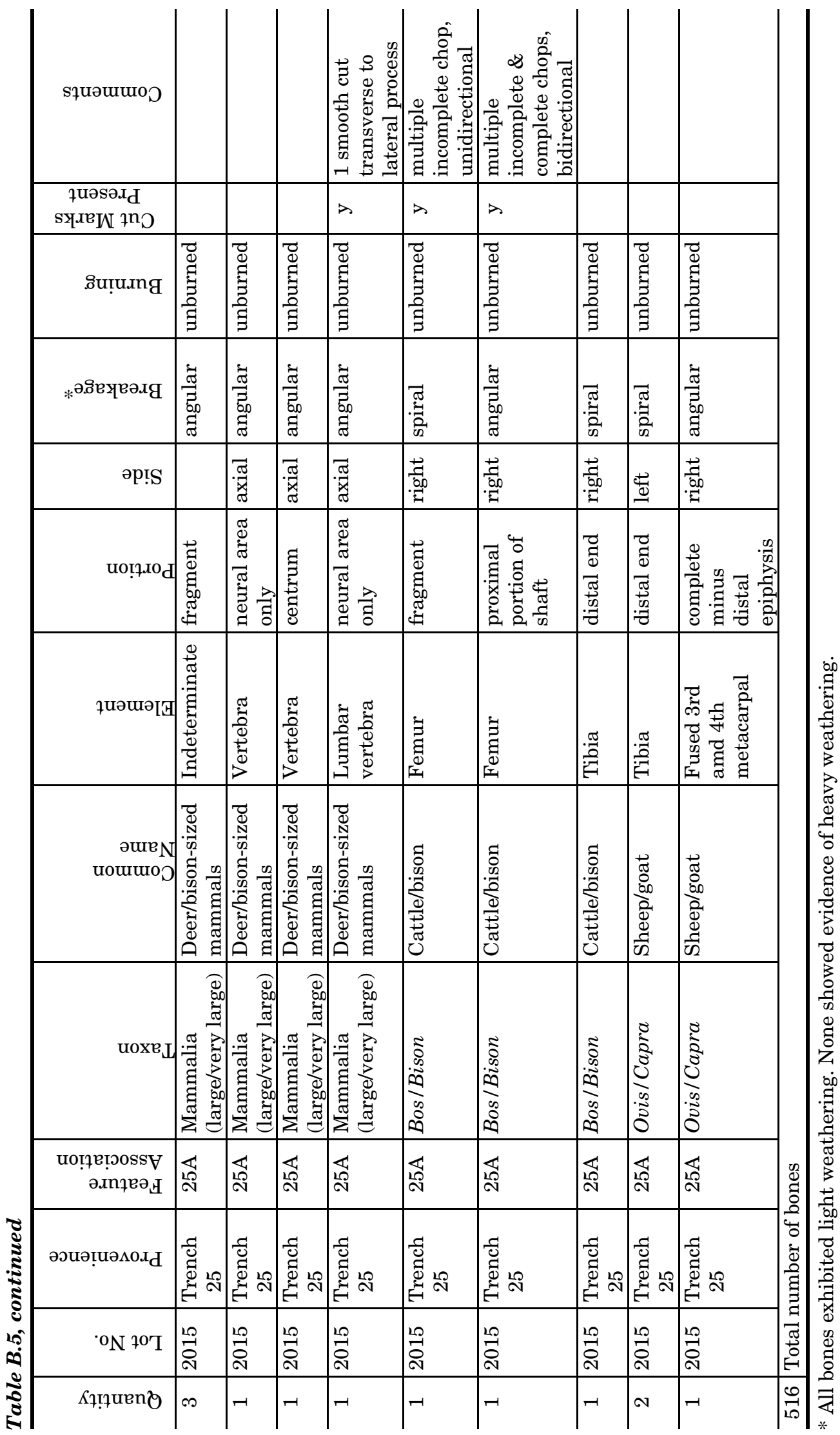




\section{REFERENCES CITED}

Balkwill, Darlene McCuaig, and Stephen L. Cumbaa 1992 A Guide to the Identification of Postcranial Bones of Bos taurus and Bison bison. Canadian Museum of Nature, Syllogeus No. 71, Ottawa.

Johnson, Eileen

1985 Current Developments in Bone Technology.

In Advances in Archaeological Method and Theory, Vol. 8, edited by M. B. Schiffer, pp. 157-235. Academic Press, New York.
Olsen, Stanley J.

1960 Post-Cranial Skeletal Characters of Bison and Bos. Papers of the Peabody Museum of Archaeology and Ethnology, Harvard University, vol. 35(4), Cambridge, Massachusetts.

Shaffer, Brian. S., and Barry W. Baker

1992 A Vertebrate Faunal Analysis Coding System: With North American Taxonomy and dBase Support Programs and Procedures (Version 3.3), Museum of Anthropology Technical Report 23. University of Michigan, Ann Arbor. 
